\title{
The merits of videolaryngoscopy during glottic visualisation for endotracheal intubation
}

Citation for published version (APA):

Maassen, R. L. J. G. (2013). The merits of videolaryngoscopy during glottic visualisation for endotracheal intubation. [Doctoral Thesis, Maastricht University]. Maastricht University. https://doi.org/10.26481/dis.20130910rm

Document status and date:

Published: 01/01/2013

DOI:

10.26481/dis.20130910rm

Document Version:

Publisher's PDF, also known as Version of record

\section{Please check the document version of this publication:}

- A submitted manuscript is the version of the article upon submission and before peer-review. There can be important differences between the submitted version and the official published version of record.

People interested in the research are advised to contact the author for the final version of the publication, or visit the DOI to the publisher's website.

- The final author version and the galley proof are versions of the publication after peer review.

- The final published version features the final layout of the paper including the volume, issue and page numbers.

Link to publication

\footnotetext{
General rights rights.

- You may freely distribute the URL identifying the publication in the public portal. please follow below link for the End User Agreement:

www.umlib.nl/taverne-license

Take down policy

If you believe that this document breaches copyright please contact us at:

repository@maastrichtuniversity.nl

providing details and we will investigate your claim.
}

Copyright and moral rights for the publications made accessible in the public portal are retained by the authors and/or other copyright owners and it is a condition of accessing publications that users recognise and abide by the legal requirements associated with these

- Users may download and print one copy of any publication from the public portal for the purpose of private study or research.

- You may not further distribute the material or use it for any profit-making activity or commercial gain

If the publication is distributed under the terms of Article $25 \mathrm{fa}$ of the Dutch Copyright Act, indicated by the "Taverne" license above, 


\section{The Merits of Videolaryngoscopy during Glottic Visualisation for Endotracheal Intubation}

\section{PROEFSCHRIFT}

ter verkrijging van de graad van doctor aan de Universiteit Maastricht, op gezag van de Rector Magnificus, Prof. dr. L.L.G. Soete volgens het besluit van het College van Decanen, in het openbaar te verdedigen op dinsdag 10 september om 10.00 uur

door

Ralph Lambertus Jozef Gerardus Maassen

geboren op 4 juni 1977 te Sittard 


\section{Promotores:}

Prof. dr. M.A.E. Marcus

Prof. dr. A.A.J. Van Zundert, University of Queensland \& Royal Brisbane \& Women's Hospital, Brisbane Queensland Australia

\section{Beoordelingscommissie:}

Prof. dr. B. Kremer (voorzitter)

Dr. M.P. Buise, Catharina Ziekenhuis, Eindhoven

Prof dr. J.G. Maessen

Prof dr. L.P.S. Stassen

Prof. dr. R.J. Stolker, UMC Rotterdam

Cover illustration: Jan-Wouter Brunings

Layout and print: Verhagen Grafische Media, Veldhoven

(C) Ralph Lambertus Jozef Gerardus Maassen

ISBN 978-90-76014-34-0

Ralph L.J.G. Maassen

Anesthesioloog

Laurentius ziekenhuis Roermond

0475382222

r.maassen@1zr.nl 


\section{STELLINGEN}

\section{behorende bij het proefschrift:}

\section{The Merits of Videolaryngoscopy during Glottic Visualisation for Endotracheal Intubation}

(1) The performance of videolaryngoscopy is superior to classic direct laryngoscopy in the easy and difficult airway (dit proefschrift)

(2) Videolaryngoscopy will become the "golden"standard for all intubations, not only those predicted to be "difficult" (dit proefschrift)

(3) A Cormack \& Lehane grade III or IV equals failed direct laryngoscopy

(4) Extralaryngeal manoeuvres may be a hindrance to endotracheal intubation (dit proefschrift)

(5) Less need for the "difficult airway trolley" thanks to videolaryngoscopy

(6) Videolaryngoscopy is as receiving a free upgrade of a hotel booking (dit proefschrift)

(7) To err is human, to forgive is divine (Alexander Pope 1688-1744)

(8) An old error is always more popular than a new truth

(9) Een tevreden mens is schatrijk een ontevreden mens straatarm (Toon Hermans)

(10) De stelling: "bezit is het einde van de droom" geldt niet voor het afronden van een promotietraject. Het biedt namelijk vele nieuwe inzichten en is het begin van nieuwe dromen. 


\section{Abbreviations}

ASA

C\&L

DA

DL

ETT

VLS(s)

GS

Storz V-MAC ${ }^{\mathrm{TM}}$

Storz C-MAC ${ }^{\mathrm{TM}}$

McGrath $^{\circledR}$
American Society of Anesthesiologists

Cormack and Lehane

Difficult airway

Direct Laryngoscopy

Endotracheal tube

Videolaryngoscope(s)

GlideScope $^{\circledast}$ (GS), Ranger ${ }^{\mathrm{TM}}$; Verathon Inc., Bothell, WA, USA

V-MACTM Storz ${ }^{\circledR}$ Berci DCI ${ }^{\circledR}$, Karl Storz, Tuttlingen, Germany

C-MACTM Storz ${ }^{\circledR}$, Karl Storz, Tuttlingen, Germany

McGrathTM Series 5; Aircraft Medical, Edinburgh, UK 


\section{Content}

\section{The Merits of Videolaryngoscopy during Glottic Visualisation for Endotracheal Intubation}

Chapter 1. Aims of the study.

Chapter 2. The videolaryngoscope is less traumatic than the classic laryngoscope for a difficult airway in an obese patient

Chapter 3. Videolaryngoscopy - making intubation more succesfull

Chapter 4. A Macintosh laryngoscope blade for videolaryngoscopy reduces stylet use in patients with normal airways

Chapter 5. A comparison of three videolaryngoscopes: the Macintosh laryngoscope blade reduces, but does not replace, routine stylet use for intubation in morbidly obese patients

Chapter 6. Letter-to-the Editor. Comparison of the C-MAC videolaryngoscope with the Macintosh, Glidescope and Airtraq laryngoscopes in easy and difficult laryngoscopy scenarios in manikins

Chapter 7. Endotracheal intubation using videolaryngoscopy causes less cardiovascular response compared to classic direct laryngoscopy, in cardiac patients according a standard hospital protocol."

Chapter 8. Airway manoeuvers - implications for airway management?

Chapter 9. General Discussion And Practical Implications

Chapter 10. English And Dutch Summary

Addenda Acknowledgements - Dankwoord

List of Publications

Curriculum Vitae 
Dedicated to my parents.....

For the memory of my father,

Wishing you were here today $\ldots \ldots \ldots \ldots \ldots \ldots \ldots \ldots \ldots$ 
Chapter 1

Aims Of The Study 


\subsection{Background}

The American Society of Anesthesiologists (ASA) states that an important cause of anaesthesia-related injury is the inability to intubate the trachea and secure the Airway (can't ventilate, can't intubate scenario) [1-3]. In the majority (85\%) of these cases, the outcome is fatal, resulting in death or brain damage. ${ }^{1}$ In patients who undergo a difficult intubation, the morbid nonfatal events ${ }^{4-7}$ are also increased. The latter refers to damage to soft tissue of the oropharynx (e.g. lips, tongue, palatopharyngeal fold, teeth), and more seriously damage to the glottis entrance (e.g. vocal cords, arytenoids, epiglottis). Moreover, the ASA closed claims analysis involving incidents of airway injury found that $80 \%$ of laryngeal injury occurs when laryngoscopy and intubation was experienced as being easy [8].

The reported incidence of difficult intubation is $1.15-3.8 \%$ in the general population, while failed intubation is much more infrequently $(0.13-0.3 \%)[2,9]$. Worldwide, up to 600 patients are estimated to die annually as a result of the complications that occur during endotracheal intubation. ${ }^{10}$ The development of difficult airway algorithms, new devices and alternative techniques to secure the airway, goes hand in hand with these facts.

A plethora of new airway management devices and techniques, such as intubation through a supraglottic airway, use of different laryngoscope blades, gumelastic bougies or stylets, blind oral or nasal intubation, retrograde intubation, a variety of rigid fibreoptic techniques and flexible (awake) fibreoptic intubation have been introduced in airway management. ${ }^{11}$ However, many of these techniques are complex, have low reliability, high cost and limited availability. Moreover, some of them are blind techniques as they do not enable us to visualize the passage of the endotracheal tube through the glottis. Successful intubation in the absence of an adequate laryngeal view, should be regarded as a "near miss" and a "failed laryngoscopy".

Poor laryngeal visualization (C\&L grade 3 and 4) with classic direct laryngoscopy (DL) is encountered between $1 \%$ and $9 \%$ of attempts, requiring prolonged or multiple intubation attempts $[2,12]$. This phenomenon probably goes hand-in-hand with complications.

Table 1 shows the range of difficulty in direct laryngoscopy and success rate of endotracheal intubation during poor laryngeal visualisation. 
Table 1. Range of Difficulty in Direct Laryngoscopy and Endotracheal Intubation

\begin{tabular}{|l|c|c|}
\hline C\&L grade at best, & RANGE OF INCIDENCE & References \\
ETT insertion outcome & $\%$ & 4,15 \\
\hline $\begin{array}{l}\text { C\&L grade 2 or 3 at best, } \\
\text { ETT insertion successful* }\end{array}$ & $1-18$ & $4,16,17$ \\
\hline $\begin{array}{l}\text { C\&L grade 3 at best, } \\
\text { ETT insertion successful* }\end{array}$ & $1-4$ & \\
\hline $\begin{array}{l}\text { C\&L grade } 3 \text { or } 4 \text { at best, } \\
\text { ETT insertion unsuccessful }\end{array}$ & $0.05-0.35$ & $4,15,16$ \\
\hline
\end{tabular}

ETT: Endotracheal tube; C\&L: Cormack and Lehane

*multiple attempts and/or blades may be required

Modified from: Benumhof J, Hagberg C. (eds) Airway Management. Third Edition, Chapter 8, 2013.

Difficult DL (C\&L grade 3 or 4) goes hand-in-hand with difficult intubation in most patients. However, there is a discordance between difficult DL and difficult endotracheal intubation. This can be explained, based on inter-observer variation of the $\mathrm{C} \& \mathrm{~L}$ grade and the need for extra adjuncts or different blades. Furthermore, pathologic conditions in the glottic entrance (such as laryngeal web, laryngeal tumors or tracheal stenosis), may disassociate ease of laryngoscopy from difficult intubation. 


\subsection{History of Laryngoscopy}

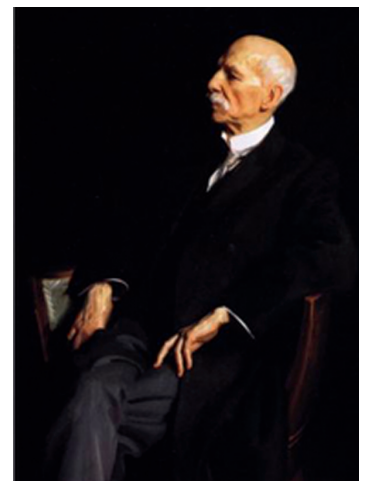

Manuel García

In 1880 the Scot William Macewen (1848-1924) described how to relieve airway obstruction by passing an oral tube into the trachea [18]. However, he practiced blind, digital intubation. In 1854, a Spanish vocal pedagogist named Manuel García (18051906) became the first man to view the functioning glottis and larynx in a living human. García developed an instrument that used two mirrors for which the sun served as an external light source. Using this device, he was able to observe the function of his own glottic apparatus and the uppermost portion of his trachea. He presented his findings at the Royal Society of London in 1855.

Several years later the American Joseph O’Dwyer developed a metal tube system that could be passed blindly to relieve airway obstruction in children suffocating from diphtheria infections [19]. In Germany, Hans Kuhn modified O'Dwyer's tube system to create a flexometallic endotracheal tube with matching introducer intended for blind insertion [20]. An important problem associated with the O'Dwyer's intubation system and its variants was that they had to be placed blindly.

The next important development in clinical airway management was the development of direct laryngoscopy, which allowed visualisation of the glottic structures. Towards the end of the 19th century, Alfred Kirstein developed an instrument which he called an "autoscope" [21], after he experienced how an endoscope intended for esophagoscopy had inadvertently slipped into the trachea. His design was subsequently modified in 1913 by Chevalier Jackson, by providing distal illumination with a light source on the distal tip, rather than the proximal light source used by Kirstein [22]. This new blade incorporated a component that the operator could slide out to allow room for passage of an endotracheal tube or bronchoscope.

In the 1940s Miller and Macintosh developed laryngoscopes which are still used in clinical airway management today. In 1941, Robert Miller described his straight laryngoscope blade [23], while in 1943 Robert Macintosh described his curved blade [24].

Macintosh hoped that by minimizing contact with the epiglottis, this laryngoscope would be less stimulating. At the same time, in Montreal, Canada in 1942, Harold Griffith introduced curare as a muscle relaxant, facilitating abdominal surgery and other surgical procedures [25]. Even 70 years later, variations of the Macintosh and Miller laryngoscopes are still in common use, occasionally both fail to provide adequate glottic visualization. Therefore, the result has been a continuing series of innovations in laryngoscope design, including developments such as fibreroptic bronchoscopes, the Bullard laryngoscope and its variants, the McCoy articulating laryngoscope, various optical stylets and the current available videolaryngoscopes. 


\subsection{Indirect Videolaryngoscopy (VLS)}

In recent years, indirect videolaryngoscopy plays an increasingly more important role in the management of patients with an (un)anticipated difficult airway or failed laryngoscopic intubation [13]. VLS intubation blades incorporate optics in their tip used for video imaging on a monitor. The view angle is increased from 15 degrees during direct laryngoscopy into 60 degrees during videolaryngoscopy (Figure 1). This distal point of viewing has been proven advantageous in improving glottic view and upgrading of Cormack and Lehane $(\mathrm{C} \& \mathrm{~L})$ grades compared to direct laryngoscopy (DL).

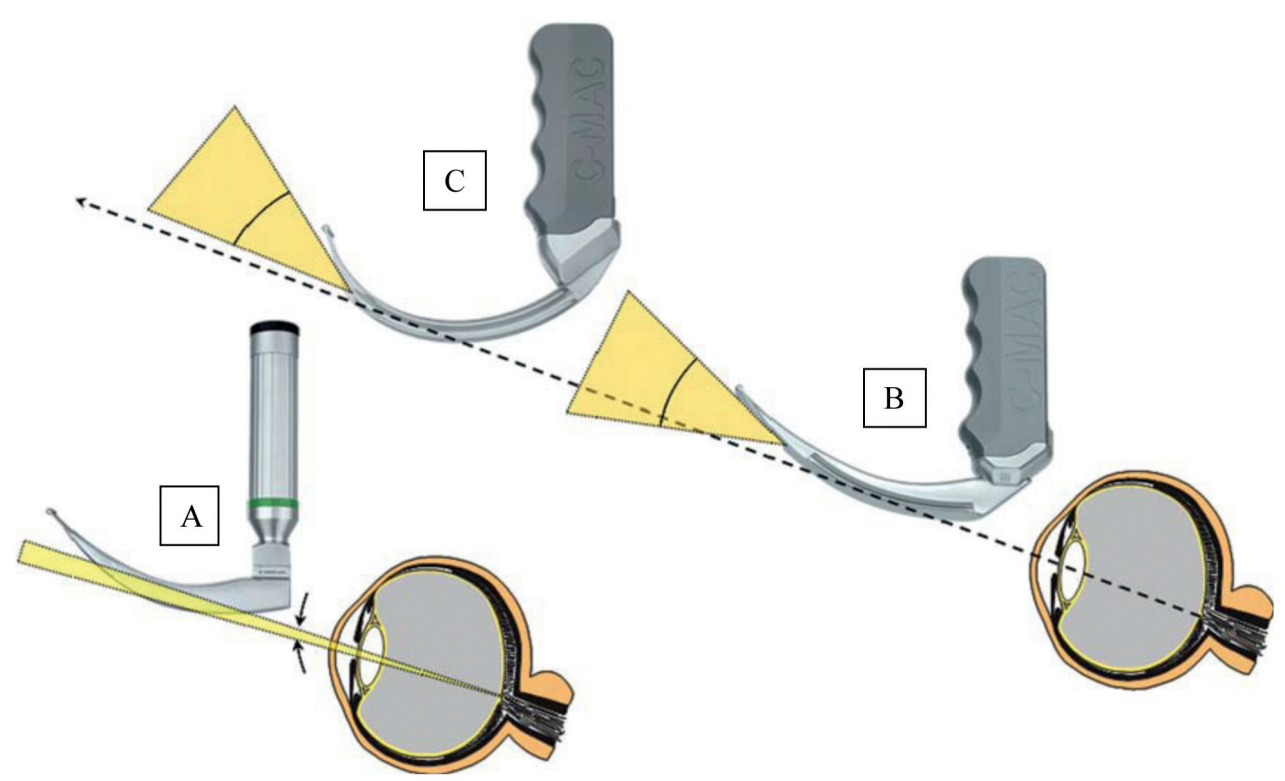

Figure 1. From: Van Zundert et al. Videolaryngoscopy allows a better view of the pharynx and larynx than classic laryngoscopy. Br J Anaesth 2012; 109: 1014-1015. A. Direct Laryngoscopy (15 ${ }^{\circ}$; Indirect videolaryngoscopy $\left(60^{\circ}\right)$ using a Macintosh-form blade (B) and a Difficult Curved D-Blade (C).

Note: point of view starts where the optics are placed at the tip of the blade $(B+C)$. 
Several VLSs with differing specifications, user interfaces and geometries have been developed. In general the VLSs can be divided in two main groups: channelled and nonchannelled VLSs.

The VLSs tested in our performance studies (Table 2) are of the non-channelled type and can respectively be devided in: (a) VLSs with standard Macintosh blades (e.g. Storz $^{\circledR}$ V-Mac and C-Mac VLSs) and (b) VLSs with angulated blades (e.g. GlideScope ${ }^{\circledR}$ and McGrath ${ }^{\circledR}$ Series 5 VLSs). Other available VLSs, not tested in our studies are VLSs with a tube channel (Pentax ${ }^{\circledR}$ Airway Scope (AWS)) and optical laryngoscopes (e.g. Bullard ${ }^{\circledR}$, Wuscope ${ }^{\circledR}$, Airtraq ${ }^{\circledR}$ VLSs).

Table 2. Videolaryngoscopes' features studied in this thesis

\begin{tabular}{|l|l|l|l|l|l|l|}
\hline VLS & $\begin{array}{l}\text { Blade shape } \\
\text { Anti-fog }\end{array}$ & Monitor & Portability & Disposability & Size range & Mechanism \\
\hline Storz V-Mac & $\begin{array}{l}\text { Standard } \\
\text { Macintosh } \\
\text { Blade }\end{array}$ & $\begin{array}{l}\text { Separate 8 In. } \\
\text { LCD monitor }\end{array}$ & No & Reusable & Pediatric, \\
adultNo & & Reusable & Sizes 2-4 & Yes \\
\hline Storz C-Mac & $\begin{array}{l}\text { Standard } \\
\text { Macintosh } \\
\text { Blade }\end{array}$ & $\begin{array}{l}\text { SFT monitor } \\
\text { TFarate 7 In. } \\
\text { Cobalt }\end{array}$ & $\begin{array}{l}\text { Yes } \\
\text { blade }\end{array}$ & $\begin{array}{l}\text { Separate 7 In. } \\
\text { LCD monitor }\end{array}$ & Yes & Single use \\
blades & Sizes 1-4 & Yes \\
\hline $\begin{array}{l}\text { GlideScope } \\
\text { Ranger }\end{array}$ & $\begin{array}{l}\text { Angulated } \\
\text { blade }\end{array}$ & $\begin{array}{l}\text { Separate 3.5 In. } \\
\text { LCD monitor }\end{array}$ & Yes & $\begin{array}{l}\text { Reusable or } \\
\text { Single use }\end{array}$ & $\begin{array}{l}\text { Reusable: } \\
\text { 3-4 Single } \\
\text { use: 1-4 }\end{array}$ & Yes \\
\hline $\begin{array}{l}\text { McGrath } \\
\text { (-series })\end{array}$ & $\begin{array}{l}\text { Angulated } \\
\text { blade }\end{array}$ & $\begin{array}{l}\text { Integrated 1.7 In. } \\
\text { LCD monitor }\end{array}$ & Yes & $\begin{array}{l}\text { Single use } \\
\text { blades }\end{array}$ & $\begin{array}{l}\text { Three adult } \\
\text { lengths Yes }\end{array}$ & \\
\hline
\end{tabular}




\subsection{Objectives of thesis}

The aim of this thesis is to determine the answers to the following questions:

- Do clinical performance studies of three common (in our hospital) available videolaryngoscopes show differences in patient outcome? (Chapter 4, 5)

- Is there a need for standard styletted endotracheal tubes during videolaryngoscopy in normal and morbidly obese airways? (Chapter 4, 5)

- Is there a difference in cardiac responses during endotracheal intubation using videolaryngoscopy compared to direct classic laryngoscopy in patients with and without beta blockade? (Chapter 7)

- What is the change in mean anterior-posterior rima glottidis (APRIMA) distance and mean area between the vocal cords after backward upward rightward pressure (BURP) and cricoid pressure (CP)? In this study the videolaryngoscope was used as a research tool. (Chapter 8)

\subsection{Outline of thesis}

Previous studies from our research group on videolaryngoscopy gave the spin off for this thesis and an extra ordinary study case (Chapter 2) describes the anaesthetic management of an obese patient with a difficult airway and the merits of videolaryngoscopy, specifically in terms of the reduced risk of dental damage during intubation.

In Chapter 3, several advantages of videolaryngoscopy over direct classic laryngoscopy are suggested. Despite the clear advantages of videolaryngoscopy over classic direct laryngoscopy, there are differences in patient outcome between the commercially available VLSs. In this chapter the need for clinical performance studies is stressed by the authors. Furthermore, we pointed out that videolaryngoscopy is a promising improvement in airway management and we believe that videolaryngoscopy will become the "golden" standard for all intubations, not only those predicted to be "difficult". In 2008, we already suggested the need for adjusting the "Difficult Airway Algorithm" with the introduction of new tools in our practice, such as videolaryngoscopy.

To overcome certain deficits of videolaryngoscopes, several manufacturers advocate the use of a styletted endotracheal tube, which may in itself be traumatic to the patient. Subsequently, we performed clinical performance studies with three common (in our hospital) available VLSs in normal and difficult airways to study the need for stylet use. In videolaryngoscopes with a Macintosh-form blade there was significantly less need for stylet use in normal airways (Chapter 4) and in airways of morbidly obese patients (Chapter 5). 
In a Letter-to-the-Editor (Chapter 6) we explained why we disagree with the statement that evaluation of videolaryngoscopes in the clinical setting receives little if any independent evaluation. McElwain et al. performed a manikin study where they compare the C-MAC VLS, with the classic Macintosh laryngoscope, the GlideScope and the Airtraq. Their findings in this manikin study are congruent to the results we experienced in our clinical performance studies (Chapter 4 and 5).

In Chapter 7, we examined the cardiovascular responses during videolaryngoscopy and classic direct laryngoscopy. The cardiovascular response curves were both tested for patients with and without beta blocker therapy. The cardiovascular responses during endotracheal intubation using videolaryngoscopy were less compared to direct classic laryngoscopy for all patients.

In Chapter 8, we used the VLS as a research tool and examined the effect of cricoid pressure (CP) and backward upward rightward pressure (BURP) on airway dimensions. This study shows a significant distortion of the upper airway anatomy after both CP and BURP manoeuvers in patients with perimetrics of a normal airway.

Chapter 9 is entitled: General Discussion and Practical Implications.

In this chapter our work on the merits of videolaryngoscopy is guardedly reviewed in order to assess the present position of videolaryngoscopy in airway management, using a SWOT analysis.

Chapter 10 includes an English and Dutch summary.

The addenda contain curriculum vitae, acknowledgment and list of publications. 


\section{References}

1. Caplan RA, Posner KL, Ward RJ, Cheney FW. Adverse respiratory events in anesthesia: a closed claims analysis. Anesthesiology 1990; 72: 828-33.

2. Crosby ET, Cooper RM, Douglas MJ, Doyle DJ, Hung OR, Labrecque P, Muir H, Murph MF, Preston RP, Rose DK, Roy L. The unanticipated difficult airway with recommendations for management. Can J Anaesth 1998; 45: 757-76.

3. Eindhoven GB, Dercksen B, Regtien JG, Borg PA, Wierda JM. A practical approach to management of the difficult airway. Eur J Anaesthesiol 2001; 23: 60-5.

4. Rose DK, Cohen MM. The airway: problems and predictions in 18,500 patients. Can J Anaesth 1994; 41: $372-83$.

5. Boëlle PY, Garnerin P, Sicard JF, Clergue F, Bonnet F. Voluntary reporting system in anaesthesia: is there a ling between undesirable and critical events? Qual Health Care 2000; 9: 203-9.

6. Givol N, Gershtansky Y, Halamish-Shani T, Taicher S, Perel A, Segal E. Perianesthetic dental injuries: analysis of incidentreports. J Clin Anesth 2004; 16: 173-6.

7. Warner ME, Benenfeld SM, Warner MA, Schroeder DR, Maxson PM. Perianesthetic dental injuries: frequency, outcomes, and risk factors. Anesthesiology 1999; 90: 1302-5.

8. Domino KB, Posner KL, Caplan RA, Cheney FW. Airway injury during anesthesia: a closed claims analysis. Anesthesiology 1999; 91: 1703-11.

9. Benumhof JL. Management of the difficult adult airway. With special emphasis on tracheal intubation. Anesthesiology 1991; 75: 1087-110.

10. King TA, Adams AP. Failed tracheal intubation. Br J Anaesth 1990; 65: 400-14.

11. American Society of Anaesthesiologists Task Force on Management of the Difficult airway. Practice guidelines for management of the difficult airway: an updated report by the American Society of Anesthesiologists Task Force on management of the Difficult Airway. Anesthesiology 2003; 98: 1269-77.

12. Combes X, Le Roux B, Suen P, Dumerat M, Motamed C, Sauvat S, Duvaldestin P, Dhonneur G. Unanticipated difficult airway in anesthetized patients: prospective validation of a management algorithm. Anesthesiology 2004; 100: 1146-50.

13. Stroumpoulis K, Pagoulatou A, Violari M, Ikonomou I, Kalantzi N, Kastrinaki K, Xanthos T, Michaloliakou C. Videolaryngoscopy in the management of the difficult airway: a comparison with the Macintosh blade. Eur J Anaesthesiol 2009; 26: 218-22.

14. Lee RA, van Zundert AAJ, Maassen RLJG, Willems RJ, Beeke LP, Schaaper JN, van Dobbelsteen J, Wieringa PA. Forces applied to the maxillary incisors during video-assisted intubation. Anesth Analg 2009; 108: $187-91$.

15. Cormack RS, Lehane J: Difficult tracheal intubation in obstetrics. Anaesthesia 1984; 39: 1105-11.

16. Samsoon GL, Young JR: Difficult tracheal intubation: A retrospective study. Anaesthesia 1987; 42: 487-90.

17. Hirsch IA, Reagan JO, Sullivan N: Complications of direct laryngoscopy: A prospective analysis. Anesthesiol Rev 1990; 17: 34.

18. Macewen W. Introduction of tracheal tubes by the mouth instead of performing tracheotomy or laryngotomy. Br Med J 1880; II: 122-4.

19. Westhorpe R. O’Dwyer's tubes. Anaesth Intensive Care 1991;19:157. 
20. Thierbach A. Franz Kuhn, his contribution to anaesthesia and emergency medicine. Resuscitation 2001; 48: 193-7.

21. Hirsch NP, Smith GB, Hirsch PO, Alfred Kirstein. Pioneer of direct laryngoscopy. Anesthesia 1986; 41: 42-5.

22. Chevalier Jackson. "The technique of insertion of intratracheal insufflation tubes". Surg Gynecol Obstet 1913; 17: 507-9.

23. Miller RA. A new laryngoscope. Anesthesiology 1941; 2: 317-20.

24. Macintosh RR. A new laryngoscope. Lancet 1943; 1: 205.

25. Griffith HR, Johnson GE. The use of curare in general anaesthesia. Anesthesiology 1942; 3: 418-20. 
Chapter 2

J Anesth (2009) 23: 445-448

DOI 10.1007/s00540-009-0780-1

\section{The videolaryngoscope is less traumatic than the classic laryngoscope for a difficult airway in an obese patient}

Ralph Maassen ${ }^{1,2}$, Ruben Lee ${ }^{3}$, André van Zundert ${ }^{1,4}$ and Richard Cooper ${ }^{5}$

\section{$\begin{array}{r}\text { Journal of } \\ \text { Anesthesia } \\ \hline \hline\end{array}$}

(C) JSA 2009

\footnotetext{
${ }^{1}$ Department of Anesthesiology, Intensive Care and Pain Therapy, Catharina Hospital - Brabant Medical School, Eindhoven, The Netherlands

${ }^{2}$ University of Maastricht, Maastricht, The Netherlands

${ }^{3}$ Department of Biomechanical Engineering, 3ME, Delft University of Technology, Delft, The Netherlands

${ }^{4}$ University of Ghent, Ghent, Belgium

${ }^{5}$ Department of Anesthesiology, Toronto General Hospital, University of Toronto, Toronto, Canada
}

Address correspondence to: A. van Zundert, Department of Anesthesiology, Catharina Hospital,

Michelangelolaan 2, NL-5623 EJ Eindhoven, The Netherlands

Received: December 29, 2008 / Accepted: April 17, 2009 


\begin{abstract}
This report describes the anesthetic management of an obese patient with a diffi cult airway and the merits of videolaryngoscopy, specifi cally in terms of the reduced risk of dental damage during intubation. A 49-year-old woman (body mass index; BMI, $36 \mathrm{~kg} \cdot \mathrm{m}^{-2}$ ), was scheduled to undergo an elective laparoscopic cholecystectomy because of cholelithiasis. Based upon the obesity of the patient and preoperative metrics (Mallampati grade IV; interdental distance of $2.9 \mathrm{~cm}$; thyromental distance, $5.5 \mathrm{~cm}$ ) a diffi cult airway was anticipated. Classic direct laryngoscopy using a Macintosh blade size IV failed, despite three intubation attempts - each resulting in a Cormack- Lehane grade IV view. Intubation using a video-assisted Macintosh laryngoscope (V-Mac; Karl Storz, Tuttlingen, Germany) was successful upon the first attempt. The maximum force exerted on the patient's maxillary incisors was $61 \mathrm{~N}$ by direct laryngoscopy and 7.6 $\mathrm{N}$ using the indirect videolaryngoscope, both using a Macintosh blade.
\end{abstract}

Key words: General anesthesia, Intubation, Videolaryngoscopy, Difficult airway, Force measurement

\title{
Introduction
}

The recent introduction of laryngoscopes incorporating optics into the blade has improved glottic visualization [1-5]. However, it is not yet clear that this reduces airway trauma or reduces intubation times. Common tests, designed to predict difficult laryngoscopy, are of uncertain relevance when videolaryngoscopy is employed [6-8].

In this report, we review a case that demonstrates the value of a videolaryngoscope for the management of a difficult airway in an obese patient, using the V-Mac Storz videolaryngoscope (Karl Storz, Tuttlingen, Germany). We measured forces applied to the maxillary incisors during direct laryngoscopy using a Macintosh blade size IV and the videolaryngoscope. This challenging case was an extraordinary inclusion in a recent study [9] measuring forces on the maxillary incisors during intubation, in which the attending anesthesiologist was blinded to the applied forces. Institutional Medical Ethics Committee approval and the patient's written informed consent were obtained.

\section{Case report}

A 49-year-old woman (height, $1.69 \mathrm{~m}$; weight, $104 \mathrm{~kg}$; body mass index [BMI], $36.4 \mathrm{~kg} \cdot \mathrm{m}^{-2}$ ) presented for elective laparoscopic cholecystectomy. She was classified as American Society of Anesthesiologists (ASA) II. Airway characteristics included a reduced interdental distance $(2.9 \mathrm{~cm})$, full dentition, reduced oropharyngeal view (Mallampati grade IV), reduced 
thyromental distance $(5.5 \mathrm{~cm})$, and normal neck movement. Both a poor glottic view and difficult intubation were anticipated.

Patient positioning was duly adjusted carefully into the ramped position prior to the induction of anesthesia, using pillows and blankets to bring the patient's sternal notch and the external auditory meatus into an imaginary horizontal line [10,11]. Direct laryngoscopy using a Macintosh blade size IV was initially selected for use with this patient. According to the study protocol, if intubation by direct laryngoscopy could not be achieved within 90 s, a backward, upward and rightsided pressure on the thyroid and cricoid cartilages (BURP) maneuver $[12,13]$ was to be employed. If the BURP maneuver failed to produce laryngeal exposure, the protocol called for the use of a videolaryngoscope.

We measured the forces on the laryngoscope blades with Flexiforce sensors (A20125; Tekscan, South Boston, MA, USA) attached to the blade of the laryngoscope at the area of contact with the maxillary teeth [9] (Fig. 1). Three sensors were mounted along the length of the blade to sufficiently cover the surface likely to contact the teeth, given that the contact point could vary for the patient. Calibration was performed by applying a known mass ( 1 to $12 \mathrm{~kg}$, in steps of $1 \mathrm{~kg}$ ), using a flat-headed screwdriver (as geometrical approximation of the contact with the teeth), to the sensors mounted upon the blade. The sensors were invariant to the contact point of the applied load. Data acquisition was achieved with a National Instruments DAQ6009 (National Instruments, Austin, TX, USA) card at $500 \mathrm{~Hz}$, using

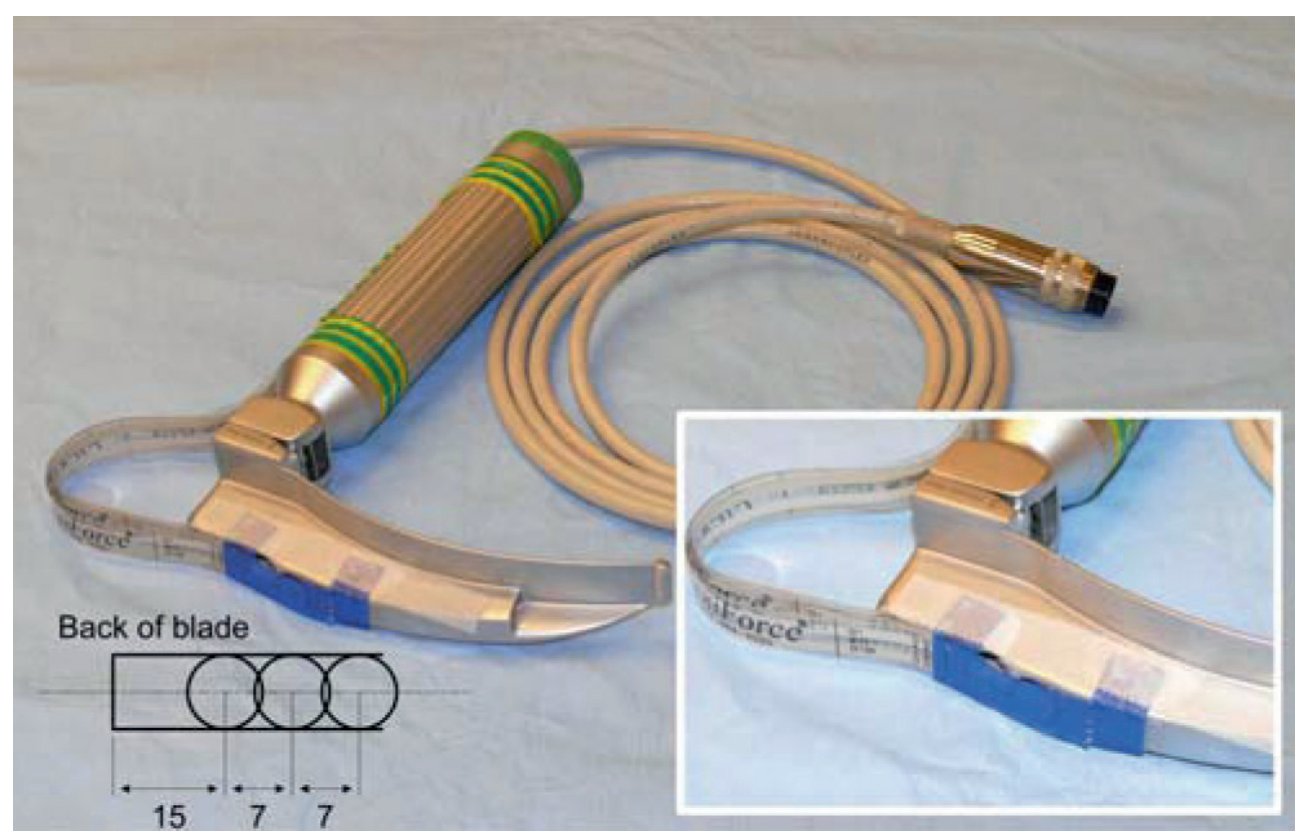

Fig. 1. Macintosh laryngoscope with sensors attached; detail of the placement of the Flexiforce (Tekscan, Boston, MA, USA) sensors used. The schematic shows the location of the sensors toward the rear of the laryngoscope blade. 
Labview 7.0 (National Instruments) on a laptop computer (Hewlett Packard, Palo Alto, CA, USA). Peak forces were subsequently noted for the laryngoscopy of the patient.

After preoxygenation for $3 \mathrm{~min}$, induction of anesthesia was carried out with intravenous $1 \mu \mathrm{g} \cdot \mathrm{kg}^{-1}$ fentanyl, $3 \mathrm{mg} \cdot \mathrm{kg}^{-1}$ propofol, and rocuronium $0.7 \mathrm{mg} \cdot \mathrm{kg}^{-1}$. The lungs were manually inflated via a facemask, using sevoflurane in oxygen. The laryngoscope was inserted approximately 2 min after completion of induction. Three intubation attempts with direct laryngoscopy failed to secure the airway, and despite external laryngeal manipulation and BURP, all revealed a Cormack-Lehane (C\&L) grade IV view. The anesthesiologist then decided to use the V-Mac Storz videolaryngoscope (Karl Storz, Tuttlingen, Germany) [14] being trialled in the hospital. Videolaryngoscopy revealed a C\&L grade I view and intubation was successful on the first attempt. The force measurements were made by an assistant, and the intubating anesthesiologist was blinded to these measurements. The maximum force on the maxillary teeth was $61.0 \mathrm{~N}$ using Macintosh direct laryngoscopy, and 7.6 N using indirect videolaryngoscopy (Fig. 2).

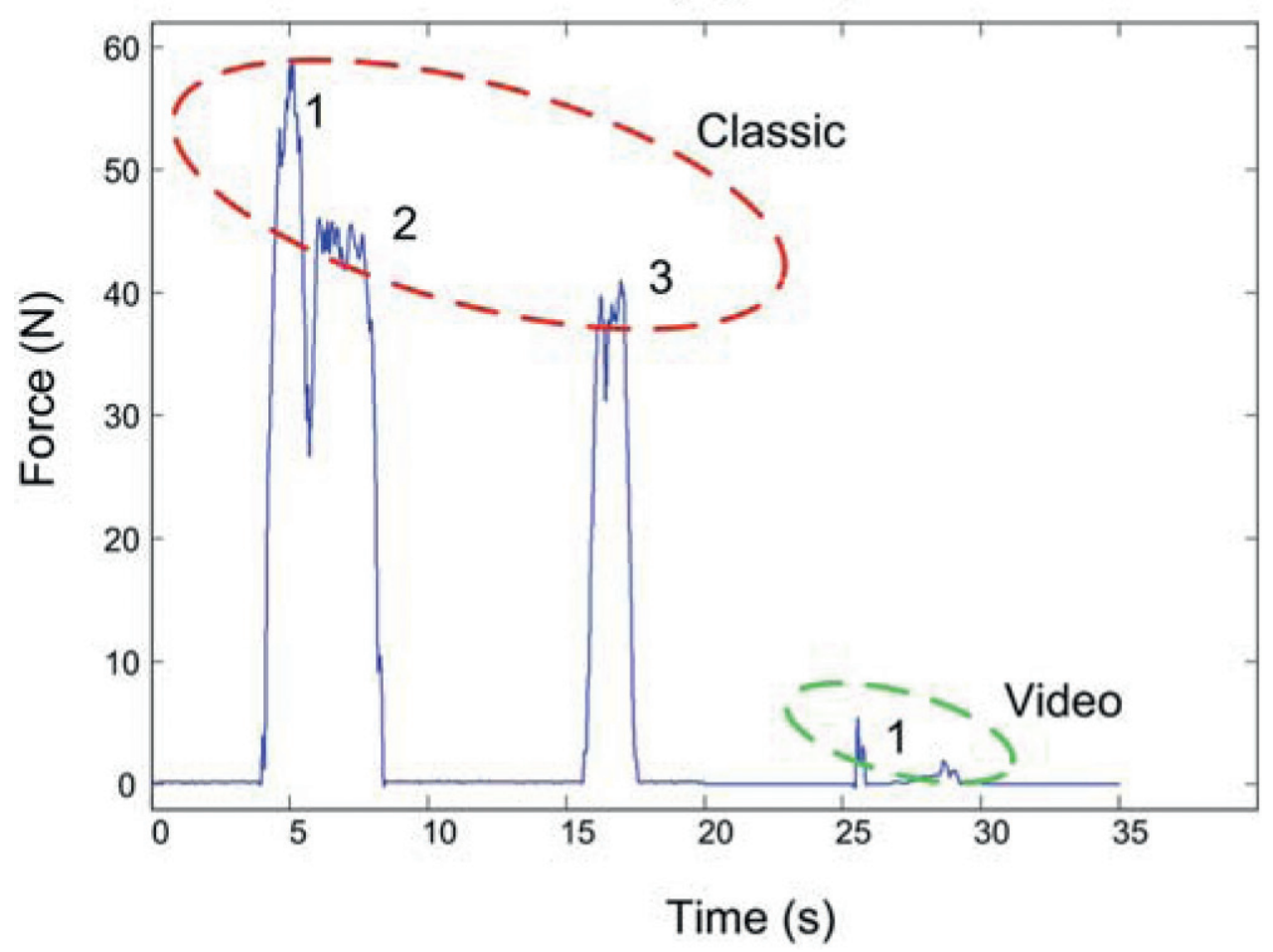

Fig. 2. Three attempts (indicated) at intubation with the classic (direct) laryngoscope show a high force applied to the maxillary incisors of the patient while trying to acquire a view of the glottis, whereas a much smaller force was applied with the (indirect) videolaryngoscope 
Peripheral oxygen saturation during this procedure stayed at more than $95 \%$, due to intermittent manual bag ventilation with $100 \%$ oxygen, between the laryngoscopy attempts. At the end of the surgical procedure, following reversal of the neuromuscular blockade, the patient resumed spontaneous ventilation and was extubated, fully awake in an upright position. No complications were encountered.

\section{Discussion}

Numerous studies using a variety of devices have compared direct laryngoscopy and indirect videolaryngoscopy.All have shown that videolaryngoscopy consistently results in improved glottic visualization [1-5]. But it remains to be demonstrated that this ensures that intubation is either faster or less traumatic. To this end, measurement of the forces applied to the maxillary incisors could be an objective measurement of the intubation difficulty or the potential for dental injury $[15,16]$. Recently, our group found that, when using videoassisted laryngoscopes, the forces exerted by the intubating anesthesiologist on the patient's maxillary incisors were reduced compared with the forces exerted with the classic Macintosh laryngoscope [9]. However, it still has to be proved whether the same will be the case in patients with difficult airways.

We were able to make continuous registrations of the forces exerted on the maxillary teeth during the intubation process in the patient reported here. The forces measured in this case report were significantly reduced when using the Storz indirect video-assisted laryngoscope compared with direct laryngoscopy, both with a Macintosh blade. The attending anesthesiologist was unaware of the forces he was exerting. Additionally, the glottic view was considerably better and intubation was successful with the videolaryngoscope on the first pass. Videolaryngoscopy does not just display the same view on a monitor screen as that shown by convenventional direct laryngoscopy; the video captured by a videolaryngoscope is very different from that of conventional direct laryngoscopy. It not only offers visualization of the glottic entrance but also shows a distal viewpoint unachievable with direct classical techniques. The Storz videolaryngoscope is inserted in a way similar to that used for a classic laryngoscope blade, as both use a Macintosh blade, diverting the tongue to the midline, making room for the insertion of an endotracheal tube. The manufacturers of other videolaryngoscopes (GlideScope, Verathon, WA, USA and Mc.Grath Series 5, Aircraft Medical, Edinburgh, UK) advocate midline insertion and the use of a styletted endotracheal tube. Both the Airway Scope (Pentax-AWS system; AWS; Pentax, Tokyo, Japan) and the Airtraq (ATQ; Prodol Meditec, Vizcaya, Spain) are anatomically shaped rigid indirect videolaryngoscope intubation devices with an adjustable built-in monitor; both devices provide an indirect view of the glottis without requiring the laryngoscope's line of sight [17-19]. These devices use a tube channel in the right side of the blade which holds the endotracheal tube and directs it towards the vocal cords. 
The application of the BURP technique and careful positioning of the patient had little influence on the laryngeal view [20,21]. Difficult airways pose a grave risk to the patient, especially in emergency situations. In a case such as the one described above (obese patient; Mallampati grade IV; C\&L, grade IV), it would often be necessary to enlist the help of additional devices and personnel. The excellent glottic view provided by the videolaryngoscope made such ancillary equipment unnecessary, and, as this case shows, reduced the need for excessive force on the laryngoscope.

A caveat remaining is that this case points to reduced forces applied to the maxillary incisors of a single patient, with a single videolaryngoscope; it is yet to be demonstrated this is also the case with different models of videolaryngoscopes. Although any contact with the maxillary teeth is undesirable, it is sometimes unavoidable when difficult laryngoscopies are encountered with classical direct laryngoscopy. Indeed, the incidence of accidental dental damage points to this phenomenon, which undoubtedly goes hand in hand with difficulty of intubation [22,23]. Perianesthetic dental injury (incidence varies from $0.04 \%$ to $12.08 \%$ ) is considered to be the most frequent (one third of total) anesthesia-related cause for insurance claims [22, 24].

In planned studies we intend to more extensively investigate the performance of various types of videolaryngoscopes; specifically, the ease of intubation in the most challenging patients previously - those with high BMI and poor Mallampati grades.

\section{Conclusion}

The present case report shows that less force was needed to visualize the glottis entrance during laryngoscopy with Macintosh blades using indirect videolaryngoscopy compared with direct laryngoscopy. Dental damage may be reduced through better facilitated viewing of the glottis. Visualization and intubation were easy with the videolaryngoscope; especially in obese patients, the videolaryngoscope may provide an alternative intubation device and show better, less traumatic intubation conditions than the classic laryngoscope.

Acknowledgments. The authors sincerely thank Guy van Dael, Mike Roelofs, and Willem Binnendijk, from the Audiovisual Department, Catharina Hospital, Eindhoven, the Netherlands, for their help with the pictures. 


\section{References}

1. Cooper RM. Use of a new videolaryngoscope (GlideScope) in the management of a difficult airway. Can J Anaesth. 2003; 50: 611-3.

2. Cooper RM, Pacey JA, Bishop MJ, McCluskey SA. Early clinical experience with a new videolaryngoscope (GlideScope) in 728 patients. Can J Anaesth. 2005; 52: 191-8.

3. Kaplan MB, Hagberg CA, Ward DS, Brambrink A, Chhibber AK, Heidegger T, Lozada L, Ovassapian A, Parsons D, Ramsay J, Wilhelm W, Zwissler B, Gerig HJ, Hofstetter C, Karan S, Kreisler N, Pousman RM, Thierbach A, Wrobel M, Berci G. Comparison of direct and video-assisted views of the larynx during routine intubation. J Clin Anesth. 2006; 18: 357-62.

4. Kaplan MB, Ward D, Hagberg CA, Berci G, Hagiike M. Seeing is believing: the importance of video laryngoscopy in teaching and in managing the difficult airway. Surg Endosc. 2006; 20 Suppl 2: S479-83.

5. Shippey B, Ray D, McKeown D. Case series: the McGrath videolaryngoscope - an initial clinical evaluation. Can J Anaesth. 2007; 54: 307-13.

6. Cormack RS, Lehane J. Difficult tracheal intubation in obstetrics. Anaesthesia. 1984; 39: 1105-11.

7. Lee A, Fan LT, Gin T, Karmakar MK, Ngan Kee WD. A systematic review (meta-analysis) of the accuracy of the Mallampati tests to predict the difficult airway. Anesth Analg. 2006; 102: 1867-78.

8. Mallampati SR, Gatt SP, Gugino LD, Desai LD, Waraksa B, Freiberger D, Liu PL. A clinical sign to predict difficult tracheal intubation: a prospective study. Can Anaesth Soc J. 1985; 32: 429-34.

9. Lee RA, van Zundert AAJ, Maassen RLJG, Willems RJ, Beeke LP, Schaaper JN, van Dobbelsteen J, Wieringa PA. Forces applied to the maxillary incisors during video-assisted intubation. Anesth Analg. 2009; 108: 187-91.

10. Brodsky JB, Lemmens HJM, Brock-Utne JG, Saidman LJ, Levitan R. Anesthetic considerations for bariatric surgery: proper positioning is important for laryngoscopy. Anesth Analg. 2003; 96: 1841-2.

11. Rich JM. Use of an elevation pillow to produce the head-elevated laryngoscopy position for airway management in morbidly obese and large-framed patients. Anesth Analg. 2004; 98: 264-5.

12. Knill RL. Difficult laryngoscopy made easy with a "BURP”. Can J Anesth. 1993; 40: 279-82.

13. Takahata O, Kubota M, Mamiya K, Akama Y, Nozaka T, Matsumoto H, Ogawa H. The efficacy of the "BURP" maneuver during a difficult laryngoscopy. Anesth Analg. 1997; 84: 419-21.

14. Van Zundert A, Stessel B, De Ruiter F, Giebelen D, Weber E. Video-assisted laryngoscopy: a useful adjunct in endotracheal intubation. Acta Anaesthesiol Belg. 2007; 58: 129-31.

15. Bucx MJ, Snijders CJ. Force, torque, and stress relaxation with direct laryngoscopy. Anesth Analg. 1996; 83: $1130-1$.

16. Bucx MJ, van der Vegt MH, Snijders CJ, Stijnen T, Wesselink PR. Transverse forces exerted on the maxillary incisors during laryngoscopy. Can J Anaesth. 1996; 43: 665-71.

17. Suzuki A, Abe N, Sasakawa T, Kunisawa T, Takata O, Iwasaki H. Pentax-AWS (Airway Scope) and Airtraq: big difference between two similar devices. J. Anesth. 2008; 22: 191-2.

18. Hirabayashi Y, Seo N. Airway Scope: early clinical experience in 405 patients. J Anesth. 2008; 22: 81-5.

19. Suzuki A, Terao M, Aizawa K, Sasakawa T, Henderson JJ, Iwasaki H. Pentax-AWS Airway Scope as an alternative for awake flexible fiberoptic intubation of a morbidly obese patient in the semi-sitting position. $\mathrm{J}$ Anesth. 2009; 23: 162-3. 
20. Snider DD, Clarke D, Finucane BT. The "BURP" maneuver worsens the glottic view when applied in combination with cricoid pressure. Can J Anaesth. 2005; 52: 100-4.

21. Takahata O, Kubota M, Mamiya K, Akama Y, Nozaka T, Matsumoto H, Ogawa H. The efficacy of the "BURP" maneuver during a difficult laryngoscopy. Anesth Analg. 1997; 84: 419-21.

22. Givol N, Gershtansky Y, Halamish-Shani T, Taicher S, Perel A, Segal E. Perianesthetic dental injuries: analysis of incident reports. J Clin Anesth. 2004; 16: 173-6.

23. Warner ME, Benenfeld SM, Warner MA, Schroeder DR, Maxon PM. Perianesthetic dental injuries: frequency, outcomes, and risk factors. Anesthesiology. 1999; 90: 1302-5.

24. Newland MC, Ellis SJ, Peters KR, Simonson JA, Durham TM, Ullrich FA, Tinker JH. Dental injury associated with anesthesia: a report of 161687 anesthetics given over 14 years. J Clin Anesth. 2007; 19: 339-45. 
Chapter 3

(Acta Anaesth. Belg., 2008, 59, 177-178)

\title{
Videolaryngoscopy - making intubation more successful
}

\author{
A.A.J. van Zundert ${ }^{1}$, R.L.J.G. Maassen², B. Hermans ${ }^{2}$ and R. A. Lee ${ }^{3}$
}

${ }^{1}$ Department of Anesthesiology, ICU \& Pain Therapy, Catharina Hospital-Brabant Medical School, Eindhoven, Netherlands, and Ghent University Hospital, Ghent, Belgium.

${ }^{2}$ Department of Anesthesiology, ICU \& Pain Therapy, Catharina Hospital-Brabant Medical School, Eindhoven, Netherlands, and Maastricht University Hospital, Maastricht, Netherlands.

${ }^{3}$ Department of Biomedical Engineering, Faculty of Mechanical, Maritime, and Materials Engineering, Delft University of Technology, Delft, The Netherlands.

Correspondence address: Prof. Dr. André van Zundert, Department of Anesthesiology, ICU \& Pain Therapy, Catharina Hospital-Brabant Medical School, Michelangelolaan 2, 5623EJ, Eindhoven, The Netherlands.

Tel.: +31 40239 9111. Fax: + 3140246 3978. E-mail: zundert@iae.nl 
Securing a patent airway in patients undergoing general anesthesia is routinely performed using direct laryngoscopy with a Macintosh laryngoscope blade. However, successive intubation attempt to pass the vocal cords can have a tremendous impact on patient outcome. A good laryngeal view is often a prerequisite, if not a guarantee, for successful intubation. There are numerous difficulties associated with intubation which can have an important effect on patient morbidity or mortality such as: 1) difficult laryngoscopy (obtaining a non-optimal view of the glottis entrance or no view of the vocal cords at all); 2) difficult intubation (for which extra tools, such as a gum elastic bougie, stylet, Bonfils, Trachlight, fiberoptic intubation, intubating laryngeal mask, ... are required); and 3) failed intubation.

Previously the paradigm for safe intubation has been built on the foundations of adequate pre-operative measurement of a patient's airway. The plethora of metrics for intubation difficulty (i.e., Mallampati, Cormack Lehane grade, BMI, mouth opening, dentition, thyromental or sternomental distances, protruding teeth, overbite, limited neck movement, are, however, usually very disappointing in predicting difficult cases of intubation. Preoperative metrics that indicate a difficult airway are not necessarily correct, while patients deemed to have 'normal' airways are not precluded from possibly difficult intubations. Therefore, the ubiquitous assessment of preoperative metrics of a potentially difficult airway by anaesthesiologists, is incomplete at best, but, furthermore, less relevant regarding videolaryngoscopy.

The recent introduction of videolaryngoscopes incorporating optics in the tip of the intubation blade has proven advantageous qua improved viewing of the glottis (Fig. 1). Further, it is assumed in literature that there are fewer traumas to the patient, with faster intubation times, even in problematic cases (Table 1). Since videolaryngoscopy facilitates indirect vision of the vocal cords, and it is no longer required to visualize the glottic entrance directly, less force is needed to lift the jaw. This has the advantage that less forces are exerted on the maxillary incisors, relative to classical direct laryngoscopy, irrespective of anaesthesiologist experience, patient characteristics, or common metrics of intubation difficulty. This potentially results in less trauma to teeth during intubation.

Videolaryngoscopes are potentially superior even for easier patients, but are most beneficial for use with difficult-to-intubate patients [1]. Especially in patients where preoperative metrics do not indicate a difficult airway and the anaesthesiologist is confronted with an unexpectedly difficult intubation the videolaryngocope can be superior to direct classic laryngoscopy. 


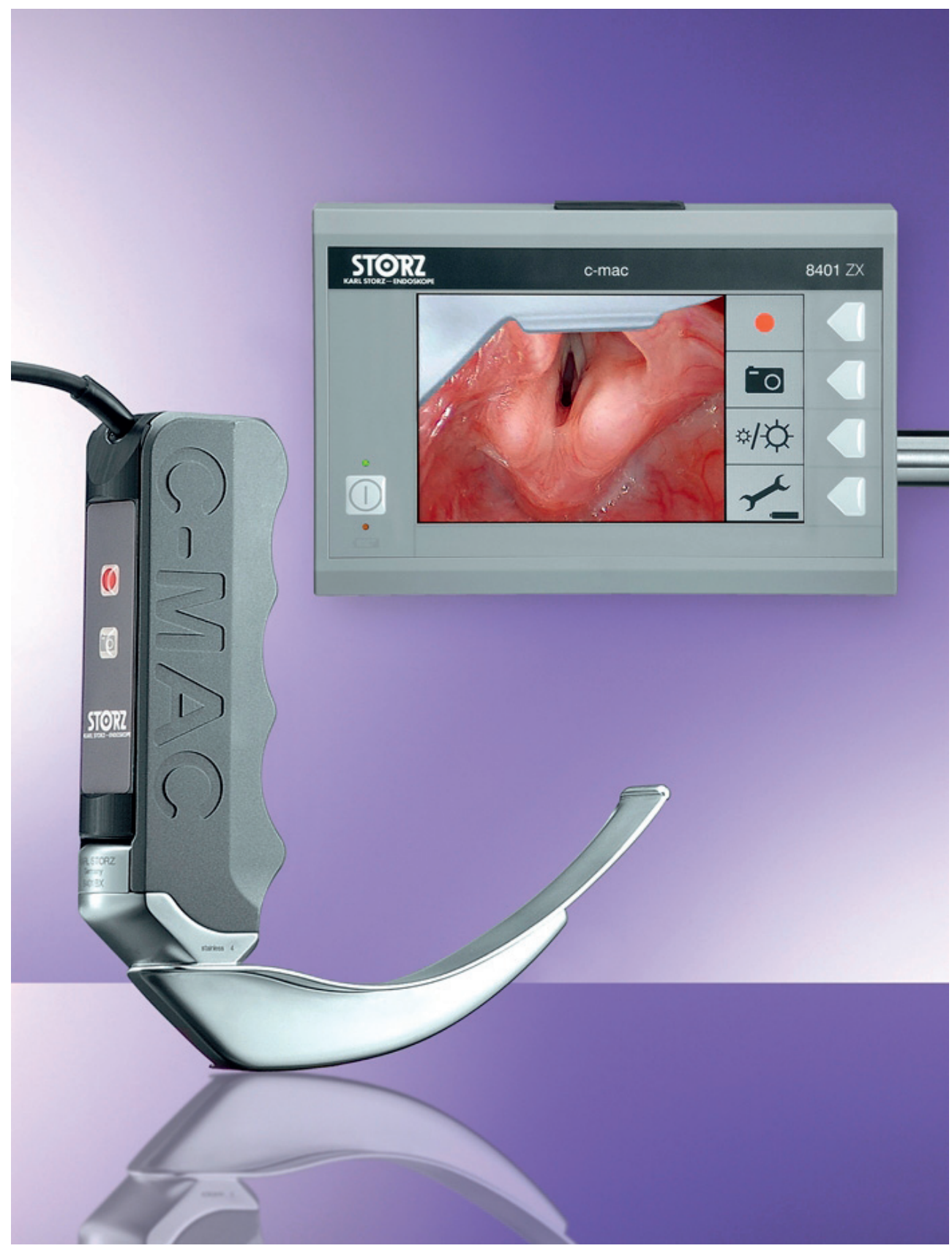

Figure 1. Example of a new videolaryngoscope (C-Mac ${ }^{\mathrm{TM}}$, Storz, Tuttlingen, Germany). 
Table 1. Suggested advantages of videolaryngoscopes

\begin{tabular}{|c|c|c|}
\hline $\begin{array}{l}\text { CLINICAL - } \\
\text { Airway management }\end{array}$ & TECHNICAL & OTHER APPLICATIONS \\
\hline 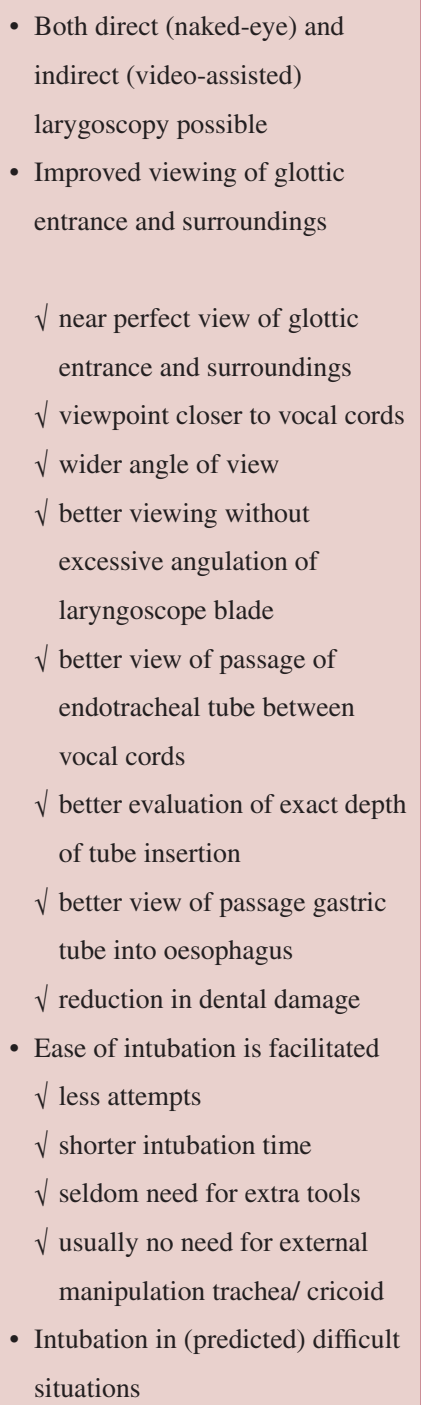 & $\begin{array}{l}\text { - Integrated video display monitor, } \\
\text { laryngoscope and cable } \\
\text { - LED lighting further improves } \\
\text { better viewing of glottis } \\
\text { - Anti-fogging } \\
\text { - AC power and DC Lithium-ion } \\
\text { battery power } \\
\text { - Colour LCD display with CMOS } \\
\text { chip } \\
\text { - Robustness (stainless steel) } \\
\text { - Heat resistant blade } \\
\text { (stainless steel) } \\
\text { - Portable } \\
\text { - Still images and video capturing } \\
\text { - SD-card MPEG/JPEG } \\
\text { - Reusable (immersable, HDL, } \\
\text { Steris) } \\
\text { Different sizes of blades fit on } \\
\text { videolaryngoscope }\end{array}$ & $\begin{array}{l}\sqrt{ } \text { better view results in more } \\
\text { diagnoses of cysts and tumours } \\
\sqrt{ } \text { other specialists can use it as } \\
\text { diagnostic t•l (e.g. ENT) } \\
\text { - Teaching/ educational tool } \\
\sqrt{ } \text { no more "look over the } \\
\text { shoulder" } \\
\sqrt{ } \text { both anaesthesiologist and } \\
\text { resident can simultaneously } \\
\text { see intubation } \\
\sqrt{ } \text { recording possible for } \\
\text { education purposes } \\
\sqrt{ } \text { documented monitoring of } \\
\text { tracheal intubation possible }\end{array}$ \\
\hline
\end{tabular}


Despite the clear advantages over classic direct laryngoscopy, there are differences in patient outcome between the commercially available videolaryngoscopes, Differences exist (e.g. successful intubation, first pass success, intubation time, use of extra tools) between the different devices. To overcome certain deficits certain manufacturers advocate using a styletted endotracheal tube, which may in itself have disadvantages. Further studies should investigate strategies for optimizing the ergonomic design of the blades for videolaryngoscopes. The integration of the videolaryngoscope blade and endotracheal tube geometry is the most pressing point for further development.

\section{Conclusion}

Successful laryngoscopy and subsequent intubation depends on the patient's characteristics and position during intubation, the intubator's skills, the technique used and the intubation tools. Besides placing the patient in an optimal position, we cannot change the patient's anatomy. The plethora of methods to predict difficult intubation conditions yield inclusive results. We, therefore, should focus our attention to technical or procedural improvements, especially the design of better laryngoscopes. Indirect videolaryngoscopy is one such improvement, as it offers a better viewpoint of the glottic entrance, often unachievable with direct classical techniques. Videolaryngoscopy is shown to have promising features. We believe that videolaryngoscopy will become standard for all intubations, not only those predicted to be 'difficult'. Consequently, the 'Difficult Airway Algorithm' guidelines have to be adjusted according to the development of the introduction of new tools in our practice, such as videolaryngoscopy.

\section{References}

1. Van Zundert A., Stessel B., de Ruiter F., Giebelen D., Weber E., Video-assisted laryngoscopy - a useful adjunct in endotracheal intubation, ACTA ANAESTH. BELG., 58, 129-131, 2007. 


\title{
Chapter 4
}

DOI: 10.1213/ane.0b013e3181ae39db

\section{A Macintosh Laryngoscope Blade for Videolaryngoscopy Reduces Stylet Use in Patients with Normal Airways}

\author{
André van Zundert, MD, PhD, FRCA ${ }^{1,2}$, Ralph Maassen, $\mathrm{MD}^{3,4}$, Ruben Lee, BE ${ }^{5}$, \\ Remi Willems, $\mathrm{MD}^{3,4}$, Michel Timmerman, $\mathrm{MD}^{3,4}$, Marc Siemonsma, MD ${ }^{3,4}$ \\ Marc Buise, $\mathrm{MD}^{1}$, Marco Wiepking, $\mathrm{MD}^{1}$
}

${ }^{1}$ Department of Anesthesiology, Intensive Care and Pain Therapy, Catharina Hospital, Brabant Medical School, Eindhoven, The Netherlands

${ }^{2}$ Department of Anesthesiology, Ghent University Hospital, Ghent, Belgium

${ }^{3}$ Department of Anesthesiology, Catharina Hospital, Eindhoven, Netherlands

${ }^{4}$ Department of Anesthesiology, University Hospital, Maastricht, The Netherlands

${ }^{5}$ Department of Biomechanical Engineering, Mechanical, Materials and Maritime Engineering, Delft University of Technology, Delft, The Netherlands

Accepted for publication April 9, 2009.

Supported by departmental funds of the Catharina Hospital, Eindhoven, the Netherlands. The videolaryngoscopes were made available to the study center, on a temporary basis, at no cost by the respective manufacturers: Ranger ${ }^{\mathrm{TM}}$ GlideScope $^{\circledast}$, Verathon Medical, Bothell, WA; V-Mac ${ }^{\mathrm{TM}}$ Storz ${ }^{\circledast}$ Macintosh, Karl Storz, Tuttlingen, Germany; and McGrath $^{\circledR}$ Series 5, Aircraft Medical, Edinburgh, UK.

All patients in this clinical study underwent surgery and anesthesia at the Catharina Hospital, Brabant Medical School, Eindhoven, The Netherlands.

Address correspondence to André van Zundert, MD, PhD, FRCA, Department of Anesthesiology, Intensive Care and Pain Therapy, Catharina Hospital - Brabant Medical School, Michelangelolaan 2, NL-5623 EJ Eindhoven, The Netherlands. Address e-mail to zundert@iae.nl.

Reprints will not be available from the author.

Copyright $@ 2009$ International Anesthesia Research Society 


\section{Abstract}

Background: Although most tracheal intubations with direct laryngoscopy are not performed with a styletted endotracheal tube, it is recommended that a stylet can be used with indirect videolaryngoscopy. Recently, there were several reports of complications associated with styletted endotracheal tubes and videolaryngoscopy. In this study, we compared three videolaryngoscopes (VLSs) in patients undergoing tracheal intubation for elective surgery: the GlideScope ${ }^{\circledR}$ Ranger $^{\mathrm{TM}}$ (GlideScope, Bothell, WA), the V-MAC ${ }^{\mathrm{TM}}$ Storz $^{\circledR}$ Berci DCI $^{\circledR}$ (Karl Storz, Tuttlingen, Germany), and the McGrath ${ }^{\circledR}$ (McGrath series 5, Aircraft medical, Edinburgh, UK) and tested whether it is feasible to intubate the trachea of patients with indirect videolaryngoscopy without using a stylet.

Methods: Four hundred fifty consecutive adults (ASA PS I-II) undergoing tracheal intubation for elective surgery were randomly allocated for airway management with one of the three devices. Anesthesia induction for tracheal intubation consisted of fentanylpropofol-rocuronium. An independent anesthesiologist used the Cormack-Lehane grading system to score an initial direct laryngoscopic view using a classic metal Macintosh blade. After subsequent positive-pressure ventilation using a face mask and an oxygen-sevoflurane mixture for $1 \mathrm{~min}$, the trachea was intubated using one of the three VLSs. During intubation, the following data were collected: intubation time, number of intubation attempts, use of extra tools to facilitate intubation, and overall satisfaction score of the intubation conditions.

Results: The trachea of every patient was intubated using the VLSs, and none of the patients required conversion to the classic Macintosh laryngoscope. All three VLSs offered equal or better view of the glottis as assessed by the mean Cormack-Lehane grade, compared with the traditional Macintosh laryngoscopy, including a larger viewing angle of the glottic entrance. The average intubation time was $34 \pm 20 \mathrm{~s}$ for the GlideScope, $18 \pm 12 \mathrm{~s}$ for the V-MAC Storz, and $38 \pm 23 \mathrm{~s}$ for the McGrath VLS. Intubation with the Storz was faster $(P$ $<0.05)$ than the other two VLS tested and necessitated fewer additional tools $(P<0.01)$, resulting in a higher first-pass successful intubation rate. A stylet had to be used in $7 \%$ of the patients in the Storz group versus about $50 \%$ of the patients when the other two VLS were used.

Conclusions: The trachea of a large proportion of patients with normal airways can be intubated successfully with certain VLS blades without using a stylet, although the three studied VLSs clearly differ in outcome. The Storz VLS displaces soft tissues in the fashion of a classic Macintosh scope, affording room for tracheal tube insertion and limiting the need for stylet use compared with the other two scopes. Although VLSs offer several advantages, including better visualization of the glottic entrance and intubation conditions, a good laryngeal view does not guarantee easy or successful tracheal tube insertion. We recommend that the geometry of VLSs, including blade design, should be studied in more detail. 


\section{Introduction}

There is clear evidence that indirect videolaryngoscopy offers improved viewing of the glottic entrance over direct classic laryngoscopy [1,2]. A better view is assumed to facilitate easier intubations, but this is not entirely confirmed [3,4], as a good laryngeal view does not guarantee easy or successful endotracheal tube (ETT) insertion. Several manufacturers are producing videolaryngoscopes (VLSs) with differing specifications, user interface, and geometry. However, the relative performance of the different models is unknown because no comparative studies have been published. Most tracheal intubations using direct laryngoscopy are performed without instruments other than the ETT itself. However, the $60^{\circ}$ angle of some VLS flanges limits the advancement of the ETT through the vocal cords into the trachea [5-7]. Some manufacturers of VLSs advocate the use of stylets with the ETT to facilitate an easier insertion into the trachea [8-10]. However, recent reports have shown rare but potentially serious complications associated with styletted ETT and VLSs [3, 11-16].

In this prospective, randomized comparative study, we evaluated, in clinical circumstances, the effectiveness of three commonly used VLSs in laryngoscopy and tracheal intubation of patients with normal airways and tested whether it is feasible to intubate the trachea with indirect videolaryngoscopy without using a stylet. Our first objective was to assess the necessity of stylet use with the VLS. It is of clinical interest to determine which VLS has the most suitable geometric and ergonomic designs for tracheal placement of a standard ETT without the use of a stylet. We hypothesized that there are significant differences in the ease of insertion of the ETT given the substantially different laryngoscope blade designs of the VLSs studied. Second, we considered intubation conditions between the blades with use of a styletted ETT. Because the stylet essentially compensates for the geometrical mismatch of the VLS with the laryngeal anatomy of the patient, we expected no discernable differences among the three VLSs. Finally, we performed a comparative assessment of the glottic view among the respective VLSs and classic direct Macintosh laryngoscopy. We hypothesized that all indirect VLSs are equal or superior to classic direct laryngoscopy in terms of the glottic view and that there are no significant differences in visualization quality among the respective VLSs. 


\section{Methods}

After approval of the hospital medical ethics committee (Catharina Hospital, Eindhoven, the Netherlands) and obtaining informed consent, 450 consecutive adult patients, undergoing intubation for elective surgery, were randomly selected to receive general anesthesia and tracheal intubation using one of three VLSs: GlideScope ${ }^{\circledR}$ (Ranger, Verathon Bothell, WA), V-Mac ${ }^{\mathrm{TM}}$ Storz $^{\circledR}$ Berci DCI $^{\circledR}$ (Storz, Karl Storz, Tuttlingen, Germany), and McGrath $^{\circledR}$ (McGrath Series 5, Aircraft Medical, Edinburgh, UK) (Fig. 1). Randomization was done through sealed envelope. Exclusion criteria were physical status ASA Class III-V; age $<18 \mathrm{yr}$; body mass index $(\mathrm{BMI})>35 \mathrm{~kg} / \mathrm{m}^{2}$; and patients with known airway pathology or cervical spine injury.

The preanesthetic visit of the patient (performed by an anesthesiologist not involved in this study) determined history of difficult intubation, measurement of common predictive indices for difficult intubation (BMI, thyromental distance, Mallampati grade, interdental [or intergum] distances), and evaluation of status of dentition and neck movement.

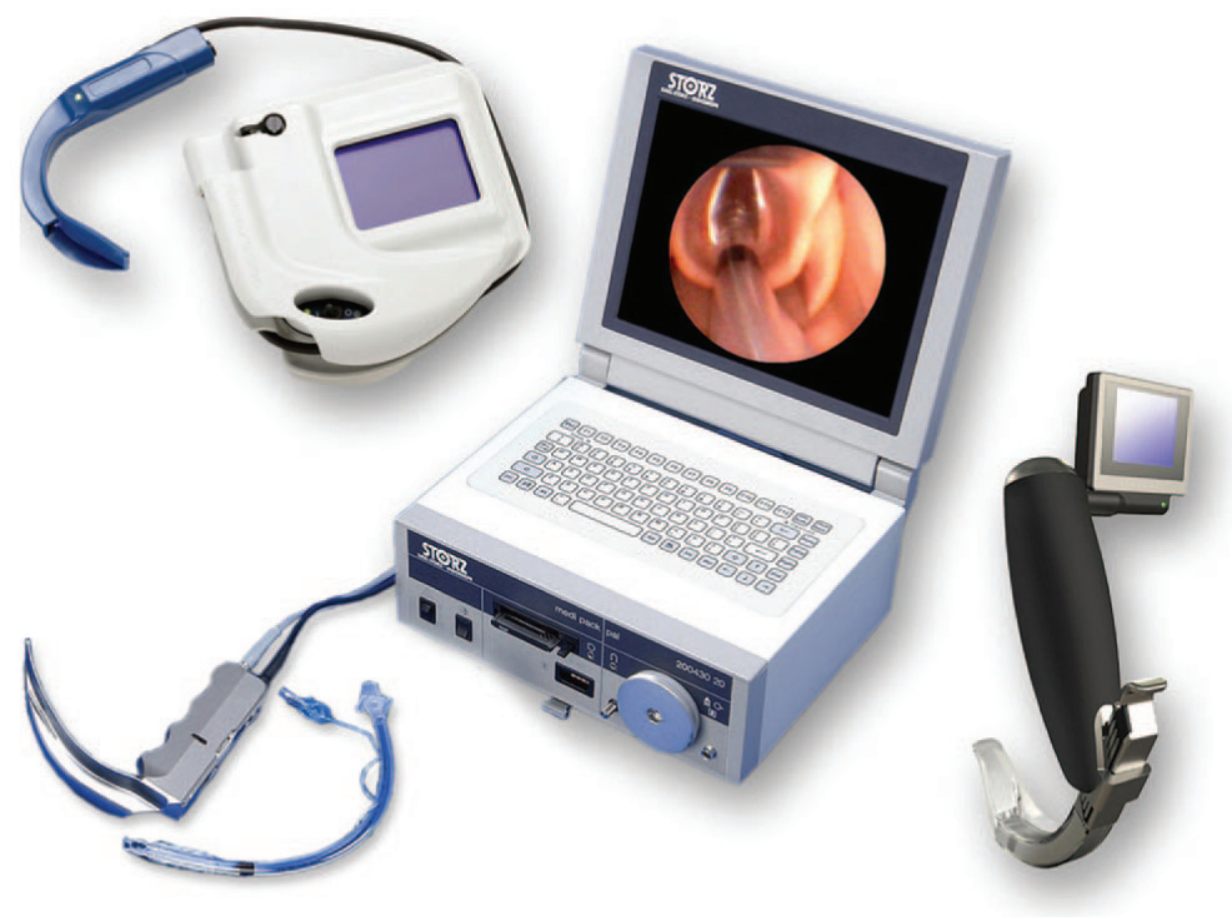

Figure 1. Photo compilation of the three videolaryngoscopes (VLSs) studied.

From left to right: the GlideScope ${ }^{\circledR}$ Ranger $^{\mathrm{TM}}$, the Storz ${ }^{\circledR}$ V-MAC ${ }^{\mathrm{TM}}$, and the McGrath ${ }^{\circledR}$ Series-5 $^{\mathrm{TM}}$ VLS. 
When the patients arrived at the operating room, they were placed in the "sniffing position" with their head placed on a pillow, connected to standard monitoring devices and breathed $100 \%$ oxygen for at least $3 \mathrm{~min}$. Anesthesia induction consisted of IV fentanyl 1.5 f. $\mathrm{Lg} / \mathrm{kg}$, propofol $3 \mathrm{mg} / \mathrm{kg}$, and rocuronium $0.7 \mathrm{mg} / \mathrm{kg}$, and the lungs were manually inflated through a face mask using sevoflurane in oxygen.

After approximately $3 \mathrm{~min}$, guided by objective confirmation of adequate degree of neuromuscular blockade (train-of-four monitoring), the same independent anesthesiologist not involved in this study performed an initial direct laryngoscopy using a classic metal Macintosh (Heine Optotechnik GmbH \& Co. KG, Herrsching, Germany) blade; laryngoscopic view was scored according to the Cormack-Lehane (C\&L) grading system, although no intubation took place. After subsequent positive-pressure ventilation using a face mask and an oxygen-sevoflurane mixture for $1 \mathrm{~min}$, the trachea was intubated using one of the three VLSs available in our hospital. The anesthesiologist performing the intubation was blinded to the C\&L laryngoscopy score given by the first anesthesiologist. All tracheal intubations were performed by one of five different anesthesiologists, all of whom were experienced in anesthesia, and the use of the VLS was studied (introduction of VLS course in airway skills laboratory and minimal of 30 uses with each VLS). During intubation, intraprocedural metrics of intubation difficulty (C\&L grade) and our dependent variables of intubation time, number of attempts, and use of extra tools to facilitate tracheal intubation were measured. In a pilot study, the use of a stylet was favored over the gum-elastic bougie. Therefore, the choice was made to use a specific rigid stylet, formed in the shape of a hockey stick with a $90^{\circ}$ bend, optimized for use with the VLS (GlideScope Rigid Stylet, Saturn Biomedical Systems, Burnaby, BC, Canada), as the first option if intubation was not feasible after two intubation attempts $[17,18]$.

The number of intubation attempts was counted as each approach of the ETT to the glottis entrance. Intubation time was measured (by an assistant) as the time between picking up the ETT (Hi-contour ${ }^{\mathrm{TM}}$, Mallincrodt Medical, Athlone, Ireland) and the visual passage of the ETT until the vocal cords were between the two black line markings on the distal end of the ETT. Interim bag and mask ventilation time, if needed, was not included in the total intubation time. More than five attempts or $120 \mathrm{~s}$ were regarded as failure of intubation. If failure to secure the airway occurs with the VLS, then conventional difficult intubation protocols from the hospital were to be implemented.

An overall satisfaction score of the intubation conditions was rated on a scale from 0 to $4: 0=$ failure, intubation not possible; 1 = poor (had to use a tool other than the VLS); $2=$ fair (need for an extra tool plus intubation time $>90 \mathrm{~s}$ ); $3=$ moderate (need for extra tool to intubate the trachea, but intubation time $<90 \mathrm{~s}$ ); and $4=\operatorname{good}$ (intubation successful on first or second attempt, within $90 \mathrm{~s}$, and no need for extra tools to secure the airway). Attention was paid to insert and remove the VLS smoothly not to damage the oral cavity, the tongue, or the patient's dentition. After removal of the VLS, the oral cavity was inspected for any bruises, lacerations, bleedings, dental damage, or other possible complications. 
Table 1. Patient Characteristics and Preprocedural Intubation Conditions

\begin{tabular}{|c|c|c|c|}
\hline Videolaryngoscope & $\begin{array}{l}\text { GlideScope Ranger } \\
\qquad(n=150)\end{array}$ & $\begin{array}{l}\text { Storz V-Mac } \\
\quad(n=150)\end{array}$ & $\begin{array}{l}\text { McGrath Series-5 } \\
\qquad(n=150)\end{array}$ \\
\hline $\begin{array}{l}\text { Male:female } \\
\qquad n \\
(\%)\end{array}$ & $\begin{array}{c}54: 96 \\
(36: 64)\end{array}$ & $\begin{array}{c}62: 88 \\
(41: 59)\end{array}$ & $\begin{array}{c}60: 90 \\
(40: 60)\end{array}$ \\
\hline Age (yr) & $50.4 \pm 16.3$ & $54.4 \pm 16.4$ & $56.2 \pm 15.3$ \\
\hline Weight (kg) & $76.3 \pm 15.7$ & $77.1 \pm 14.6$ & $76.1 \pm 14.6$ \\
\hline Height (m) & $1.71 \pm 0.09$ & $1.71 \pm 0.09$ & $1.70 \pm 0.09$ \\
\hline ASA & $1.52 \pm 0.51$ & $1.59 \pm 0.51$ & $1.59 \pm 0.49$ \\
\hline Body mass index $\left(\mathrm{kg} / \mathrm{m}^{2}\right)$ & $26.1 \pm 4.27$ & $26.3 \pm 4.04$ & $26.3 \pm 4.10$ \\
\hline Thyromental distance $(\mathrm{cm})$ & $7.3 \pm 1.1$ & $7.4 \pm 1.0$ & $7.5 \pm 1.1$ \\
\hline Max mouth opening (cm) & $4.4 \pm 0.6$ & $4.3 \pm 0.6$ & $4.3 \pm 0.6$ \\
\hline $\begin{array}{l}\text { Mallampati grade } \\
\text { Mean } \pm \text { sd } \\
\text { (I:II:III:IV) }\end{array}$ & $\begin{array}{l}1.65 \pm 0.66 \\
68: 66: 16: 0\end{array}$ & $\begin{array}{l}1.75 \pm 0.65 \\
55: 77: 18: 0\end{array}$ & $\begin{array}{l}1.70 \pm 0.66 \\
61: 72: 17: 0\end{array}$ \\
\hline $\begin{array}{l}\text { Dentition } \\
\text { Double denture:single:none, } n \\
\text { Percentage }\end{array}$ & $\begin{array}{l}117: 6: 27 \\
78: 4: 18\end{array}$ & $\begin{array}{c}104: 12: 34 \\
69: 8: 23\end{array}$ & $\begin{array}{c}101: 13: 36 \\
67: 9: 24\end{array}$ \\
\hline
\end{tabular}

ASA = American Society of Anesthesiologists.

A priori sample size testing was conducted assuming an analysis of variance (ANOVA) model for the time measurements. Using three treatments (blade), an effect size of $5 \mathrm{~s}$ from clinical experience, a highdesired statistical power level of 0.95 and a level of 0.05 , we calculated a sample size of 50 patients. We expanded the patient group to account for the three hypotheses tested and necessary correction of the sample size (i.e., Bonferroni). Data were reported as mean ( \pm sd) and incidences (both absolute and percentage). ANOVA was used to assess any differences among the groups regarding the patient-specific characteristics (i.e., age, BMI, thyromental distance, and interdental distance). Nonparametric patient metrics (i.e., gender, ASA PS, and dentition) were evaluated for differences among the groups using Kruskal-Wallis one-way ANOVA. The differences in the dependent parameters of intubation time, attempts, use of additional tools, and overall satisfaction for the respective VLS groups was evaluated using Kruskal-Wallis non-parametric one-way ANOVA (to forgo assumptions of normality) and Bonferroni correction for the multiple hypothesis testing. Finally, the C\&L grades were compared for each of the tested VLSs and the classical Macintosh blade again using Kruskal-Wallis one-way ANOVA. All statistical analysis was performed using MATLAB $^{\circledR} 7.2$ (R2006a) (Mathworks, MA). P < 0.05 was considered statistically significant. 


\section{Results}

Patient characteristics and preprocedural intubation conditions did not differ among patient groups (Table 1). Patients underwent a large variety of general surgery, orthopedic surgery, urology, gynecology, and plastic surgery. Peripheral oxygen saturation was maintained above $95 \%$ in all patients throughout the laryngoscopy and intubation period. All operations were completed uneventfully. We did not detect any injury of the palatoglossal arch or dental injury in any patient. Minor lip lacerations were seen in four patients.

The first hypothesis concerned the differences between the VLSs studied in their effectiveness for intubation without a stylet. Intubation was successful on the first attempt in 46 patients $(53 \%)$ with the GlideScope, 118 patients $(84 \%)$ with the Storz, and 32 patients (52\%) with the McGrath VLS, all without using a stylet (Table 2). A stylet had to be used to successfully intubate almost half the patients in the GlideScope group $(n=64,43 \%)$ and the McGrath group ( $n=88,59 \%)$; however, it was less for the Storz group $(n=10,7 \%),(P<0.01)$ (Fig. 2). The Storz group required fewer attempts to secure the airway (Kruskal-Wallis, $\chi^{2}=$ $126, P<0.01$ ), (Table 2) with and without stylet. The average intubation times were $34 \pm 20 \mathrm{~s}$ for the GlideScope, $18 \pm 12 \mathrm{~s}$ for the Storz, and $38 \pm 23 \mathrm{~s}$ for the McGrath VLS (Table 2), again considering the total intubation attempts, both with and without stylet. Intubation with the Storz VLS was faster than the other two VLSs tested (Kruskal-Wallis, $\chi^{2}=116, P<0.01$ ) (Fig. 3 ).

Concerning the second hypothesis, there were no differences using a stylet among the three VLSs with regard to the number of required intubation attempts $(\mathrm{P}>0.05)$. A successful intubation was achieved on the first pass with the stylet in 49 patients (76\%) who used the GlideScope, eight patients (80\%) who used the Storz, and 65 patients (74\%) who used the McGrath. However, because we did not differentiate the time before and after using a stylet, we cannot draw any conclusions regarding differences in intubation time. Subjectively, there did not seem to be any differences concerning the intubation time among the three VLSs when using a stylet. All VLSs performed well in terms of effective intubation time necessary for securing the airway because it was not necessary to revert to standard difficult airway protocols.

No dropouts were encountered, as the tracheas of all patients could be intubated using the VLSs. All the VLSs tested offered an equal or better view of the glottis as assessed by the mean $C \& \mathrm{~L}$ grade compared with traditional direct intubation techniques $(P<0.01)$ (Fig. 4). Only very few patients had C\&L grades other than Grade I with the VLS, and none of the patients included in this study had a C\&L grade poorer than II. The VLSs tested were rated favorably for their larger viewing angle of the glottic entrance compared with classic laryngoscopy techniques. This proved useful for guidance of the ETT and nasogastric tube into position and avoidance of contact with soft tissues of the mouth and pharynx. In general, visualization of the glottis entrance with the VLS was not a problem, although intubation was not always straightforward. In the context of this study, overall satisfaction was greater using the Storz VLS compared with the other two VLSs (Kruskal-Wallis, $\chi^{2}=95, P<0.01$ ). 
Table 2. Intubation Metrics

\begin{tabular}{|c|c|c|c|}
\hline & $\begin{array}{l}\text { GlideScope Ranger } \\
\qquad(n=150)\end{array}$ & $\begin{array}{l}\text { Storz V-Mac } \\
\qquad(n=150)\end{array}$ & $\begin{array}{c}\text { McGrath Series-5 } \\
\quad(n=150)\end{array}$ \\
\hline \multicolumn{4}{|l|}{ Intubation attempts } \\
\hline Mean \pm sd & $2.23 \pm 1.00 *$ & $1.30 \pm 0.63 * *$ & $2.52 \pm 1.00$ \\
\hline $1: 2: 3:>4$ & $46: 40: 49: 15^{*}$ & $118: 22: 8: 2 * *$ & $32: 30: 65: 23$ \\
\hline Percentage & $31: 27: 33: 10$ & $79: 15: 5: 2$ & $22: 20: 44: 15$ \\
\hline \multicolumn{4}{|l|}{ Intubation attempts without stylet } \\
\hline 1 attempt, n (\%) & $46(53)$ & $118(84)^{* *}$ & $32(52)$ \\
\hline 2 attempts, n (\%) & $40(47)$ & $22(16)^{* *}$ & $30(48)$ \\
\hline Total, n (\% from all subjects) & $86(57)$ & $140(93)^{* *}$ & $62(41)$ \\
\hline \multicolumn{4}{|l|}{ Intubation attempts with stylet } \\
\hline 1 attempt, n (\%) & $49(76)$ & $8(80)$ & $65(74)$ \\
\hline$>2$ attempts, $\mathrm{n}(\%)$ & $15(24)$ & $2(20)$ & $23(26)$ \\
\hline Total, n (\% from all subjects) & $64(43)$ & $10(7)$ & $88(59)$ \\
\hline \multicolumn{4}{|l|}{ Intubation Time } \\
\hline Mean $\pm \mathrm{sd}(\mathrm{s})$ & $34 \pm 20^{*}$ & $18 \pm 12 * *$ & $38 \pm 23$ \\
\hline \multicolumn{4}{|l|}{ Cormack-Lehane grade, mean \pm sd } \\
\hline Classic laryngoscope & $1.68 \pm 0.76$ & $1.68 \pm 0.81$ & $1.77 \pm 0.83$ \\
\hline VLS & $1.01 \pm 0.11$ & $1.01 \pm 0.11$ & $1.01 \pm 0.08$ \\
\hline \multicolumn{4}{|l|}{ Overall satisfaction score } \\
\hline Good:moderate:fair:poor:failure, $n$ & $87: 59: 4: 0: 0^{*}$ & 140:10:0:0:0** & $62: 83: 5: 0: 0$ \\
\hline Percentage & $58: 39: 3: 0: 0$ & 93:7:0:0:0 & $42: 55: 3: 0: 0$ \\
\hline
\end{tabular}

* Statistically significant difference over McGrath $(\mathrm{P}<0.05)$.

** Statistically significant difference over other tested videolaryngoscopes (VLSs) $(\mathrm{P}<0.01)$. 


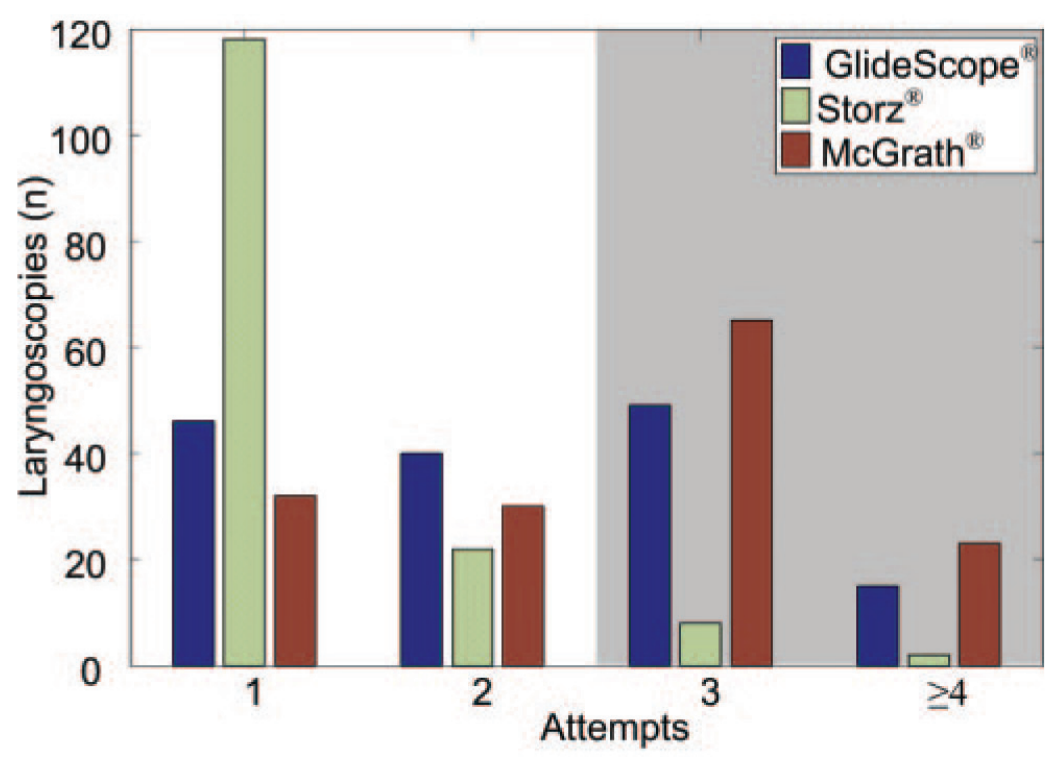

Figure 2. Comparison of necessary intubation attempts using three VLSs. There are less attempts necessary with the Storz ${ }^{\circledR}$ VLS than with both the GlideScope ${ }^{\circledR}$ and the McGrath $^{\circledR}$ VLS $(P<0.01)$ and less attempts necessary with the GlideScope than with the McGrath VLS $(P<0.05)$. The gray shading indicates attempts that were done with the addition of a stylet (i.e., more than two attempts).

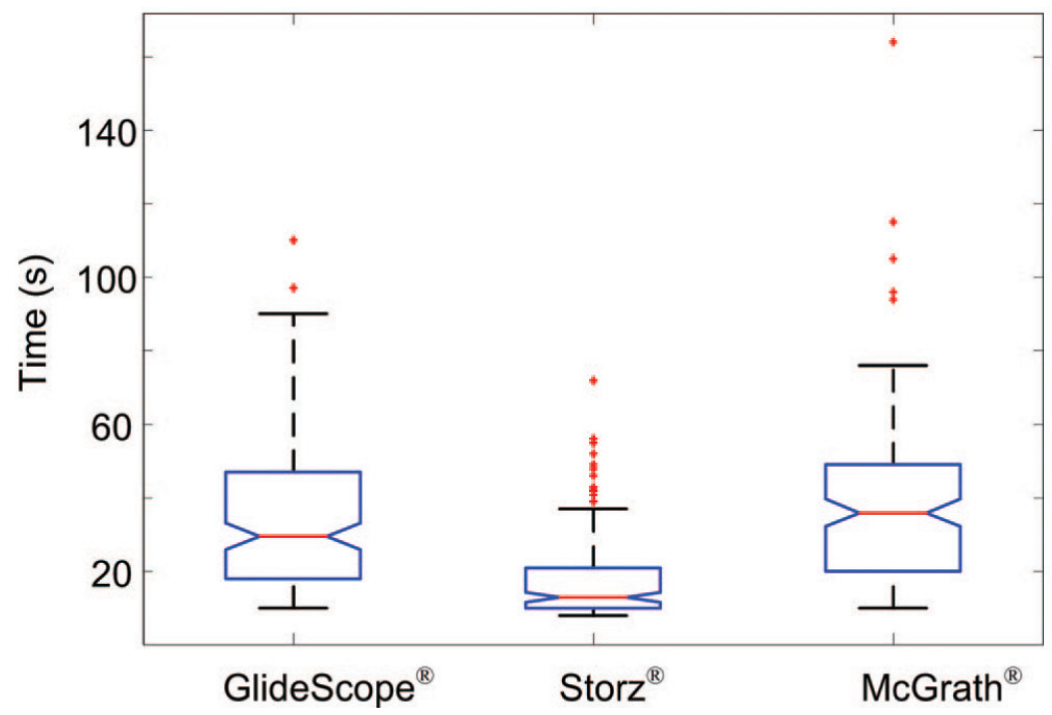

Figure 3. Comparison of necessary intubation time for three VLSs. There is less time required to intubate with the Storz ${ }^{\circledR}$ VLS than with both the GlideScope ${ }^{\circledR}$ and the McGrath ${ }^{\circledR}$ VLS $(P<0.01)$, and less time necessary with the GlideScope than with the McGrath VLS $(P<0.05)$. 


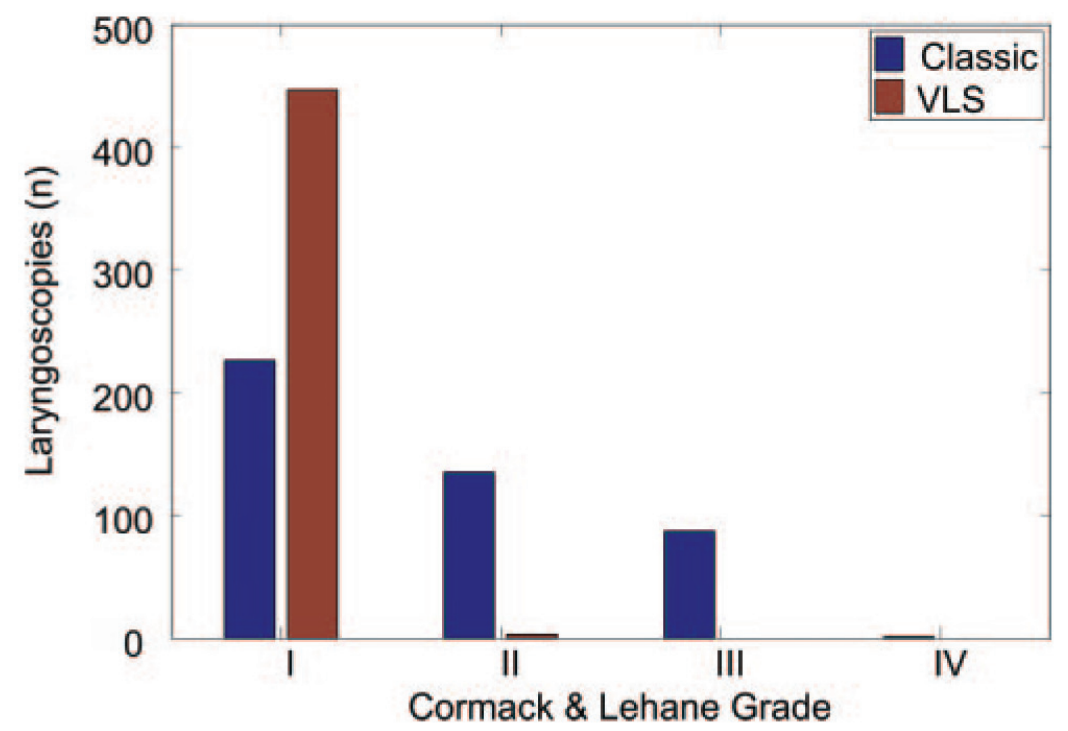

Figure 4. Comparison of Cormack-Lehane (C\&L) grades for the pooled VLSs versus the direct Macintosh blade. There were significantly better C\&L grades for each of the indirect VLS compared with the direct view $(P<0.01)$.

\section{Discussion}

This study compares three VLS devices in a clinical setting during endotracheal intubation and confirms that a stylet is not necessary with some VLSs (Storz) but highly recommended when other VLSs (e.g., GlideScope and McGrath) are used. When using a stylet, the VLSs studied did not differ in intubation time or number of intubation attempts. This study also confirms the excellent unobstructed view of the glottic opening obtained indirectly with a VLS as opposed to the direct classic Macintosh laryngoscope.

No conversion to direct laryngoscopy was necessary in any patients studied. An equal or better C\&L grade could be obtained in all cases, which is in agreement with other studies.19,20 There were no significant differences in the visualization quality of the glottis among the three VLSs except for the dimension of the device monitor. Good visualization of the glottic entrance is paramount for successful tracheal intubation. However, providing a good view of the glottis does not always correlate with successful intubation. Indeed, this study shows that devices that offer the same unhindered view of the glottis are not alike in their ease of use. 
This study demonstrates that stylet use is not always required with certain VLSs. The Storz VLS group was associated with a shorter intubation time, required significantly fewer attempts to secure the airway compared with the other two groups, and a stylet was required only in a minority $(7 \%)$ of the patients, whereas a styletted ETT had to be used in almost half of the patients in the GlideScope and McGrath VLS groups. Presumably, this is due to the fact that the Storz VLS uses the same Macintosh laryngoscope blade as with direct laryngoscopy, providing a better view and better access, which decreases the need for stylet use. During direct laryngoscopy, a stylet is rarely used routinely at first attempt in our clinical practice. Given the fact that styletted ETT have rare but potentially significant complications, we believe it is important to reserve their use for difficult intubations [3, 11-16].

Using a styletted ETT with the GlideScope VLS, the first pass success rates were higher in the studies performed by Sun et al. [21]. (94\%) and Xue et al. [22]. (97\%) compared with our study. However, the other studies used a different definition of a "single pass" in which a successive attempt was only recorded on retracting the ETT completely out of the mouth; in our study, each approach to the vocal cords was counted as an attempt. Similarly, Shippey et al. [10]. also found a first pass success rate of $93 \%$ when using the McGrath VLS and a styletted ETT. In our study, successful intubation (without using a stylet) in the Storz group was 93\%, supporting our contention that a stylet is not needed at all times and, thus, preventing potential complications. Successful intubation with the Storz VLS (without stylet) is as good as with the reported success rate in the literature using the GlideScope/ McGrath VLS (with stylet). [10,20-22]. The direct laryngoscope and the indirect Storz VLS are generally inserted on the right side of the tongue, which is compressed and deflected laterally, whereas the indirect GlideScope and McGrath VLS are inserted in the midline and advanced over the tongue because there is no need to sweep the tongue laterally. It might be that the greater success rate using the Storz VLS without a stylet depends on the angle of its blade, which is similar to the conventional direct Macintosh laryngoscope and the fact that the tongue is displaced laterally. Presumably, use of a styletted ETT from the outset would mitigate the differences among the VLSs that we found; however, this may also increase the risk of injury. The addition of a stylet essentially compensates for the geometrical shortcomings of some of the VLS designs.

Since its commercial introduction in 2002, numerous studies have reported the efficacy and safety of the GlideScope VLS for tracheal intubation in patients (and simulators) with easy and difficult airways [1,5,20,23,24].

However, some authors have noted that the GlideScope VLS is difficult to insert into the patient's mouth, does not reach deep enough in some cases, insertion of ETT is not easy, the advancement of the ETT after removal of the stylet is difficult,22 and complications because of the use of a styletted ETT and a VLS may occur [3,11-16]. 
The arytenoid cartilages, the interarytenoid soft tissues, anterior commissure of the glottis, or the anterior wall of the cricoid cartilage sometimes interfere with advancement of the ETT into the trachea. Manipulation of the ETT orientation is often not sufficient because the curvature of the distal end of the ETT is insufficient; in such cases, an extra tool is necessary. Additionally, patient characteristics, such as dentition and mouth opening, may greatly influence the ease of insertion of the ETT. The VLS essentially positions the operator's eye proximal to the larynx. Therefore, care should be taken to do the initial introduction (passing the teeth and first part of mouth) of the ETT directly, until the distal end comes into view of the VLS. Indeed, the VLS is essentially a standard laryngoscope in form and function until the critical insertion of the ETT through the vocal cords is performed.

A number of techniques can be used during the intubation procedure to improve the success rate. Previously, Xue et al. [22]. noted that the use of a malleable stylet, preheating of the blade to body temperature, and avoiding the use of superfluous lubricant were important considerations for successful use of the GlideScope. Also, increased lifting force, withdrawal and reinsertion of the blade, and external laryngeal pressure have been proposed as helpful measures for successfully securing the airway [23]. Several maneuvers may overcome the problem of inserting the ETT: relaxing the VLS; withdrawing the VLS 1-2 cm; use of a StyletScopeTM (Nihon Kohden Co., Tokyo, Japan) in which the operator can adjust the angle of the ETT tip between $30^{\circ}$ and $90^{\circ}$ by gripping the handle strongly [25]; or the use of a styletETT that can increase the angle between the axis of the ETT tip and the tracheal axis. We neither experience any improvement in the ease of intubation when using external laryngeal pressure nor withdrawal and reinserting the blade. In this study, it was noticed that the use of a stylet with a relatively pronounced curve (the best angle is reported to be $90^{\circ}$ ) $[17,18]$ at the distal end was most helpful in advancing the tip of the ETT to the glottic opening.

Further study is required to determine optimal geometrical forms for the stylet or gumelastic bougies used for difficult intubations. More importantly, the integration of the ETT with the VLS blade is the major issue for redesign in future generations of VLS, especially considering that the classical problem of visualization now seems to be resolved (all patients in our study showed a C\&L I or II with all three types of VLSs).

The McGrath VLS that uses a disposable blade and the recent introduction of the GlideScope Cobalt single-use disposable blades [26] are promising developments, especially in busy settings in which there may not be sufficient time to sterilize the blades between uses. Portability of the VLS systems is also an issue, and there are clear advantages of the McGrath and GlideScope VLS over the Storz. The integration of an antifogging mechanism on the McGrath and the GlideScope VLS is advantageous over the Storz V-Mac VLS, which lacks this feature. Preheating the VLS with the former two is unnecessary because the light emitting diode heats a window over the video chip. If fogging does occur, it likely means that the VLS is defective. However, it is still possible to blur the view if the lubricated ETT makes contact with the imaging system. 
This study has several limitations: 1) The attending anesthesiologist was not blinded to the type of VLS used, which this may have introduced bias, despite being blinded to the preoperative metrics and initial $\mathrm{C} \& \mathrm{~L}$ grade with the use of the classic Macintosh laryngoscope; 2) There are more VLSs available on the market so this review is not complete, but the three most common models available in our hospital are included; 3) There was very low patient morbidity in this study, and it remains debatable how important the metrics of intubation time, attempts, and satisfaction are with regard to patient morbidity; 4) It is clear that if the study were performed using a stylet routinely in all cases, then the second or third intubation attempt would not have been necessary; 5) The selection of patients lacking features associated with a difficult airway may have reduced the potential superiority of VLS over direct laryngoscopy and minimized the differences among the three VLS models; 6) Failure to routinely use a stylet may bias our study in favor of a device which most closely resembles a conventional Macintosh laryngoscope; 7) A study of patients with difficult airway anatomy may be needed to determine the need for the routine use of a stylet; and 8) Finally, this study deals with a specific population of elective surgical patients with normal airways and no conclusions can be made for patients in whom difficult tracheal intubation is expected.

\section{Conclusions}

The use of a styletted ETT is not ideal during tracheal intubation because it can potentially contribute to complications. Our study confirms that a large proportion of patients with normal airway anatomy can be intubated successfully with certain VLS blades without using a stylet, although there is a large difference among the types of VLSs tested. Certainly, the problem of visualization of the glottic arch is resolved by a VLS, but this does not guarantee easy or successful endotracheal intubation. The stylet essentially compensates for the geometrical mismatch between the VLS blade and the laryngeal anatomy of the patient.

The Storz VLS performed better in overall satisfaction, intubation time, and number of attempts, including attempted intubations without a stylet, most probably due to the better view and access, which limited the need for stylet use. The GlideScope and McGrath VLS are equally successful in achieving good visualization and intubation in all patients. It seems that geometry and integration of ETT with the VLS is the next question that needs to be addressed in blade design for intubation. 


\section{References}

1. Cooper RM. Use of a new videolaryngoscope (GlideScope) in the management of a difficult airway. Can $\mathbf{J}$ Anaesth 2003; 50: 611-3.

2. Van Zundert A, Stessel B, De Ruiter F, Giebelen D, Weber E. Video-assisted laryngoscopy: a useful adjunct in endotracheal intubation. Acta Anaesthesiol Belg 2007; 58: 129-31.

3. Cooper RM. Complications associated with the use of the GlideScope videolaryngoscope. Can J Anaesth 2007; 54: 54-7.

4. Kaplan MB, Ward D, Hagberg CA, Berci G, Hagiike M. Seeing is believing: the importance of video laryngoscopy in teaching and in managing the difficult airway. Surg Endosc 2006; 20 (suppl 2): S479 -S483.

5. Cooper RM, Pacey JA, Bishop MJ, McCluskey SA. Early clinical experience with a new videolaryngoscope (GlideScope) in 728 patients. Can J Anaesth 2005; 52: 1918.

6. Kramer DC, Osborn IP. More maneuvers to facilitate tracheal intubation with the GlideScope. Can J Anaesth 2006; $53: 737$.

7. Muallem M, Baraka A. Tracheal intubation using the GlideScope with a combined curved pipe stylet, and endotracheal tube introducer. Can J Anaesth 2007;54:778.

8. Cuchillo JV, Rodriguez MA. Considerations aimed at facilitating the use of the new GlideScope videolaryngoscope. Can J Anaesth 2005; 52: 661; author reply 661-2.

9. Shippey B, Ray D, McKeown D. Case series: the McGrath videolaryngoscope - an initial clinical evaluation. Can J Anaesth 2007; 54: 307-13.

10. Shippey B, Ray D, McKeown D. Use of the McGrath videolaryngoscope in the management of difficult and failed tracheal intubation. Br J Anaesth 2008; 100: 116-9.

11. Vincent RD Jr, Wimberly MP, Brockwell RC, Magnuson JS. Soft palate perforation during orotracheal intubation facilitated by the GlideScope videolaryngoscope. J Clin Anesth 2007; 19: 619 -21.

12. Choo MK, Yeo VS, See JJ. Another complication associated with videolaryngoscopy. Can J Anaesth 2007; 54: 3224.

13. Hirabayashi Y. Pharyngeal injury related to GlideScope videolaryngoscope. Otolaryngol Head Neck Surg 2007; 137: 1756.

14. Hsu WT, Hsu SC, Lee YL, Huang JS, Chen CL. Penetrating injury of the soft palate during GlideScope intubation. Anesth Analg 2007; 104: 1609 -11.

15. Malik AM, Frogel JK. Anterior tonsillar pillar perforation during GlideScope video laryngoscopy. Anesth Analg 2007; 104: 1610-1.

16. Hsu WT, Tsao SL, Chen KY, Chou WK. Penetrating injury of the palatoglossal arch associated with use of the GlideScope videolaryngoscope in a flame burn patient. Acta Anaesthesiol Taiwan 2008; 46: 3941.

17. Jones PM, Turkstra TP, Armstrong KP, Armstrong PM, Cherry RA, Hoogstra J, Harle CC. Effect of stylet angulation and endotracheal tube camber on time to intubation with the GlideScope. Can J Anaesth 2007; 54: $21-7$.

18. Turkstra TP, Harle CC, Armstrong KP, Armstrong PM, Cherry RA, Hoogstra J, Jones PM. The GlideScopespecific rigid stylet and standard malleable stylet are equally effective for Glide-Scope use. Can J Anaesth 2007; 54: 8916 . 
19. Kaplan MB, Hagberg CA, Ward DS, Brambrink A, Chhibber AK, Heidegger T, Lozada L, Ovassapian A, Parsons D, Ramsay J, Wilhelm W, Zwissler B, Gerig HJ, Hofstetter C, Karan S, Kreisler N, Pousman RM, Thierbach A, Wrobel M, Berci G.

20. Comparison of direct and video-assisted views of the larynx during routine intubation. J Clin Anesth 2006; 18: 35762 .

20. Xue F, Zhang G, Liu J, Li X, Sun H, Wang X, Li C, Liu K, Xu Y, Liu Y. A clinical assessment of the Glidescope videolaryngoscope in nasotracheal intubation with general anesthesia. J Clin Anesth 2006; 18: 611-5.

21. Sun DA, Warriner CB, Parsons DG, Klein R, Umedaly HS, Moult M. The GlideScope video laryngoscope: randomized clinical trial in 200 patients. Br J Anaesth 2005; 94: 3814.

22. Xue FS, Zhang GH, Liu J, Li XY, Yang QY, Xu YC, Li CW. The clinical assessment of Glidescope in orotracheal intubation under general anesthesia. Minerva Anestesiol 2007; 73: 451-7.

23. Fun WL, Lim Y, Teoh WH. Comparison of the GlideScope video laryngoscope vs. the intubating laryngeal mask for females with normal airways. Eur J Anaesthesiol 2007; 24: 486 -91.

24. Lai HY, Chen IH, Chen A, Hwang FY, Lee Y. The use of the GlideScope for tracheal intubation in patients with ankylosing spondylitis. Br J Anaesth 2006; 97: 419 -22.

25. Hirabayashi Y. The StyletScope(R) facilitates tracheal intubation with the GlideScope ${ }^{\circledR}$. Can J Anaesth 2006; 53: 12634.

26. Jones PM, Harle CC, Turkstra TP. The GlideScope cobalt videolaryngoscope-a novel single-use device. Can J Anaesth 2007; 54: 6778 . 


\title{
Chapter 5
}

DOI: 10.1213/ANE.0b013e3181b7303a

\section{A Comparison of Three Videolaryngoscopes: The Macintosh Laryngoscope Blade Reduces, but Does Not Replace, Routine Stylet Use for Intubation in Morbidly Obese Patients}

\author{
Ralph Maassen, $\mathrm{MD}^{1,2}$, Ruben Lee, $\mathrm{BE}^{3}$, Boukje Hermans, $\mathrm{MD}^{1,2}$, \\ Marco Marcus, MD, $\mathrm{PhD}^{2}$, André van Zundert, $\mathrm{MD}, \mathrm{PhD}, \mathrm{FRCA}^{1,4}$
}

${ }^{1}$ Department of Anesthesiology, Catharina Hospital, Eindhoven

${ }^{2}$ Department of Anesthesiology, University Hospital, Maastricht

${ }^{3}$ Department of Biomechanical Engineering, Mechanical, Materials and Maritime Engineering, Delft University of Technology, Delft, The Netherlands

${ }^{4}$ Department of Anesthesiology, University Hospital, Ghent, Belgium

Accepted for publication June 24, 2009.

Supported by departmental funds of the Catharina Hospital, Eindhoven, The Netherlands.

All patients included in this clinical study underwent surgery and anesthesia at the Catharina HospitalBrabant Medical School, Eindhoven, The Netherlands.

Reprints will not be available from the author.

Address correspondence to Dr. André van Zundert, Department of Anesthesiology, Intensive Care and Pain Therapy, Catharina Hospital-Brabant Medical School, Michelangelolaan 2, NL-5623 EJ Eindhoven, The Netherlands. Address E-mail to zundert@iae.nl.

Copyright @ 2009 International Anesthesia Research Society 


\section{Abstract}

Background: Many manufacturers are producing videolaryngoscopes (VLSs) with differing specifications, user interfaces, and geometry. It is clinically relevant to know the relative performance of the blades. Visualization of the glottis and intubation are often problematic in (extremely) obese patients, and the new video technology may offer better functionality and performance. Although many tracheal intubations with direct laryngoscopy are performed with an unstyletted endotracheal tube, it is recommended to use a stylet for intubation using videolaryngoscopy. In this study, we compared 3 VLSs in morbidly obese patients undergoing intubation for elective surgery and tested whether it is feasible to intubate the tracheas of morbidly obese patients without using a stylet.

Methods: One hundred fifty consecutive adult morbidly obese patients (body mass index $>35 \mathrm{~kg} / \mathrm{m}^{2}$ ) were randomly selected to receive one of $3 \mathrm{VLSs}$ : GlideScope ${ }^{\circledR}$, Storz ${ }^{\circledR}$ V-Mac ${ }^{\mathrm{TM}}$, and McGrath ${ }^{\circledR}$. Direct laryngoscopy scored the best possible view of the glottis; subsequently, the respective VLS was used, and the patient's trachea was intubated. Common preprocedural (e.g., Mallampati grade) and intraprocedural (Cormack-Lehane grade) metrics of intubation difficulty were measured, as well as the dependent variables of intubation time, number of attempts, and subjective difficulty.

Results: All 3 VLSs tested offered an equal or better view of the glottis compared with traditional direct laryngoscopy. The number of attempts necessary to intubate the trachea differed significantly among VLSs (average $2.6 \pm 1.0$ attempts for the GlideScope, $1.4 \pm 0.7$ for the Storz, and $2.9 \pm 0.9$ for the McGrath VLS). The average intubation times were $33 \pm 18$ $\mathrm{s}$ for the GlideScope, $17 \pm 9 \mathrm{~s}$ for the Storz, and $41 \pm 25 \mathrm{~s}$ for the McGrath VLS.

Conclusions: In this study, the VLS with the Macintosh blade (Storz VLS) had a better overall satisfaction score, intubation time, number of intubation attempts, and necessity of extra adjuncts, compared with the 2 other tested devices. 


\section{Introduction}

Difficult tracheal intubation using direct laryngoscopy is more common in morbidly obese patients (body mass index [BMI] 2:35 kg/m2).1,2 It has been shown that videolaryngoscopy improves intubation conditions in this challenging (and growing) patient population.3 The routine use of a styletted endotracheal tube (ETT) with videolaryngoscopy is advocated by some manufacturers4- 6 but has been questioned recently 7 because styletted ETTs have rare but potentially important complications when videolaryngoscopes (VLSs) are used.6,8 -16 We therefore hypothesize that it is important to reserve stylets for difficult intubations.

In this study, we compared 3 VLSs in morbidly obese patients undergoing intubation for elective surgery: the GlideScope ${ }^{\circledR}$ Ranger $^{\mathrm{TM}}$, the Storz ${ }^{\circledR}$ V-MAC ${ }^{\mathrm{TM}}$, and the McGrath ${ }^{\circledR}$ VLS and tested whether it is feasible to intubate the tracheas of obese patients with a VLS without using a stylet.

\section{Methods}

After approval from the hospital medical ethics committee (Catharina Hospital, Eindhoven, The Netherlands) and obtaining informed consent, 150 consecutive adult patients scheduled for surgeries requiring endotracheal intubation, with a BMI more than $35 \mathrm{~kg} / \mathrm{m}^{2}$, were randomly selected to undergo tracheal intubation using one of 3 VLSs: GlideScope (Ranger, Verathon, Bothell, WA); V-MAC Storz Berci DCI (Karl Storz, Tuttlingen, Germany); and McGrath (McGrath Series 5, Aircraft Medical, Edinburgh, UK). Exclusion criteria were ASA physical status III-V, patients younger than $18 \mathrm{yr}$, patients with a BMI $<35 \mathrm{~kg} / \mathrm{m}^{2}$, and patients who had known airway pathology or cervical spine injury. Randomization was done prospectively with a sealed envelope technique.

The preanesthetic visit (performed by an anesthesiologist not involved in this study) ascertained history of difficult intubation, measurement of common predictive indices for difficult intubation (BMI, thyromental distance, Mallampati grade, interincisal [or intergingival] distances), and evaluation of status of dentition and neck movement.

When the patients arrived at the operating room, they were connected to standard monitoring devices and administered oxygen for at least $3 \mathrm{~min}$. Anesthesia induction consisted of IV fentanyl $1.51-\mathrm{g} / \mathrm{kg}$ and propofol $3 \mathrm{mg} / \mathrm{kg}$ based on estimated lean body weight. Manual mask ventilation and inflation of the lungs was attempted via a face mask using sevoflurane in oxygen before rocuronium $0.7 \mathrm{mg} / \mathrm{kg}$ was administered once the ability to mask ventilate the patient was verified. 
After approximately $3 \mathrm{~min}$, all patients underwent an initial direct laryngoscopy, by an independent anesthesiologist, using a classic metal Macintosh (Heine Optotechnik GmbH \& Co. KG, Herrsching, Germany) blade to score the Cormack-Lehane (C\&L) grade, although no intubation took place. After subsequent mask positive pressure ventilation, the trachea was intubated using the patient's designated VLS. The anesthesiologist performing the intubation was blinded to the laryngoscopy (C\&L) score as assessed by the first anesthesiologist. All tracheal intubations were performed by one of 5 different anesthesiologists, all of whom were experienced in anesthesia and the use of the VLS studied (introductory videolaryngoscopy course in airway skills laboratory and a minimum of 50 uses of each VLS). During intubation, intraprocedural metrics of intubation difficulty were measured, as well as the dependent variables of intubation time, number of attempts, and use of rigid stylet to facilitate intubation. In a pilot study, using a stylet was favored to a gum-elastic bougie. Therefore, the choice was to use a specific rigid stylet17,18 formed in the shape of a hockey stick with a $90^{\circ}$ bend, optimized for use with the VLS (GlideScope Rigid Stylet, Saturn Biomedical Systems, Burnaby, B.C., Canada), and was the first option if intubation was not feasible after 2 intubation attempts in all 3 VLSs. A gum-elastic bougie was always at hand, as was the difficult intubation cart.

The number of intubation attempts was counted as each approach of the ETT to the glottic entrance. Intubation time was measured (by an assistant) as the time between picking up the ETT (Hi-contour ${ }^{\mathrm{TM}}$, Mallincrodt Medical, Athlone, Ireland) and the visual passage of the tube until the vocal cords were between the 2 black line markings on the distal end of the ETT. Interim bag and mask time, if needed, was not included in the intubation time. More than 5 attempts or $120 \mathrm{~s}$ was regarded as failure of intubation. If failure to secure the airway occurred with the VLS, then conventional difficult intubation protocols approved by the hospital were to be implemented. Attention was paid to insert and remove the VLS smoothly in order not to damage the oral cavity, the tongue, or the patient's dentition. After removal of the VLS, the oral cavity was inspected for any bruises, lacerations, bleeding, dental damage, or other possible complications.

The intubating anesthesiologist was asked to provide an overall satisfaction score of the intubation conditions scoring from 0 to 4 : 0 = failure (intubation not possible); $1=$ poor (had to use an adjunct other than the VLS); 2 = fair (need for an extra adjunct plus intubation time $>90 \mathrm{~s}$ ); 3 = moderate (need for extra adjunct to intubate the trachea but intubation time $<90 \mathrm{~s}$ ); 4 = good (intubation successful on first or second attempt, within $90 \mathrm{~s}$, and no need for extra adjunct to secure the airway).

A priori sample size testing was conducted assuming an analysis of variance (ANOVA) model for the time measurements. Using 3 treatments (blades), an effect size of $5 \mathrm{~s}$ from clinical experience, a high desired statistical power of 0.95 , and a value of 0.05 , we calculated a sample size of 50 patients. Data are reported as mean ( $\pm \mathrm{sd})$ and incidences (both absolute and percentage). ANOVA analysis was used to assess any differences among the groups regarding the patientspecific characteristics (BMI, thyromental distance, and interincisal 
distance). Nonparametric patient metrics (gender, ASA status, and dentition of the patient) were evaluated for differences among the groups using Kruskal-Wallis one-way ANOVA. The differences in the dependent variables of intubation time, number of attempts, use of additional adjuncts, and overall satisfaction for the respective VLS groups were calculated using Kruskal-Wallis nonparametric one-way ANOVA (to forgo assumptions of normality). We applied a conservative correction using Bonferroni. The $\mathrm{C} \& \mathrm{~L}$ grades were compared for each of the tested VLSs and the classical Macintosh blade using Kruskal-Wallis one-way ANOVA. All statistical analyses were performed using SPSS 16.0 (SPSS, Chicago, IL). P < 0.05 was considered statistically significant.

\section{Results}

Patient characteristics and preprocedural intubation conditions did not differ among patient groups (Table 1). Peripheral oxygen saturation was maintained above $95 \%$ in all patients throughout the laryngoscopy and intubation period. In this study, no dropouts were encountered, because all patients were intubated successfully using the VLS. No patients required conversion to classic Macintosh laryngoscopy, and all operations proceeded uneventfully. We did not detect any injury of the palatoglossal arch or dental injury in any of the patients.

Table 1. Patient Characteristics and Preprocedural Intubation Conditions

\begin{tabular}{|l|c|c|c|}
\hline Videolaryngoscope & $\begin{array}{c}\text { GlideScope }{ }^{\circledR} \text { Ranger } \\
(n=50)\end{array}$ & $\begin{array}{c}\text { Storz }{ }^{\circledR} \text { V-MACTM } \\
(n=50)\end{array}$ & $\begin{array}{c}\text { McGrath } \\
(n=50)\end{array}$ \\
\hline Male/female, $n(\%)$ & $16 / 34(32 / 68)$ & $21 / 29(42 / 58)$ & $15 / 35(30 / 70)$ \\
\hline Age (yr) & $45.9 \pm 15$ & $47.7 \pm 14$ & $128.3 \pm 14$ \\
\hline Weight (kg) & $127.0 \pm 26$ & $126.9 \pm 28$ & $1.72 \pm 0.1$ \\
\hline Height (m) & $1.71 \pm 0.1$ & $1.73 \pm 0.10$ & $2(1-2)$ \\
\hline ASA (median, range) & $2(1-2)$ & $2(1-2)$ & $43.3 \pm 7$ \\
\hline Body mass index (kg/m $\left.{ }^{2}\right)$ & $43.2 \pm 8$ & $42.4 \pm 8$ & $7.8 \pm 1$ \\
\hline Thyromental distance (cm) & $7.7 \pm 1$ & $7.8 \pm 1$ & $4.4 \pm 1$ \\
\hline Interincisal distance (cm) & $4.4 \pm 1$ & $4.4 \pm 1$ & $2(1-3)$ \\
\hline $\begin{array}{l}\text { Mallampati grade (median, range) } \\
\text { I/II/III/IV }\end{array}$ & $\begin{array}{c}2(1-4) \\
10 / 27 / 11 / 2\end{array}$ & $2(1-4)$ & $12 / 26 / 12 / 0$ \\
\hline $\begin{array}{l}\text { Dentition } \\
\text { Full dentures/single/none, } n(\%)\end{array}$ & $37 / 4 / 9(74 / 8 / 18)$ & $36 / 2 / 12(72 / 4 / 24)$ & $38 / 5 / 7(76 / 10 / 14)$ \\
\hline
\end{tabular}


All of the VLSs tested offered an equal or better view of the glottis (Grades I and II) as assessed by the $\mathrm{C} \& \mathrm{~L}$ grade, compared with traditional direct laryngoscopy intubation techniques (Grades I-IV) (P 0.01). In general, visualization of the glottic entrance with the VLS was never a problem, although intubation was not always straightforward. The number of attempts necessary to intubate the trachea differed significantly among the VLS blades (average 2.6 1.0 attempts for the GlideScope, 1.4 0.7 for the Storz, and 2.9 0.9 for the McGrath VLS). The Storz group required statistically fewer attempts to secure the airway (Kruskal-Wallis, $\chi^{2}=56, \mathrm{P}<0.01$ ) (Fig. 1) when considering the total number of intubation attempts (i.e., with and without stylet). Intubation was successful on the first attempt in 8 patients with the GlideScope, 34 with the Storz, and 4 with the McGrath, all without using a stylet (Table 2). A stylet had to be used in the majority of the patients in the GlideScope group $(\mathrm{n}=30,60 \%)$ and the McGrath group $(n=38,76 \%)$. However, this was not the case for the Storz group, which showed less need for a stylet $(n=5,10 \%)(P<0.01)$.

The C\&L grade as assessed with classic VLS influenced the number of attempts necessary ( $\mathrm{P}<0.01$ ) to intubate the trachea (Fig. 2). All VLSs performed well in terms of effective intubation time necessary for securing the airway. The average intubation times were $33 \pm 18 \mathrm{~s}$ for the GlideScope, $17 \pm 9 \mathrm{~s}$ for the Storz, and $41 \pm 25 \mathrm{~s}$ for the McGrath, again considering the total intubation time, both with and without stylet. Intubation with the Storz VLS was significantly faster than with the other 2 VLSs tested (Kruskal-Wallis, $\chi^{2}=60$, $\mathrm{P}<0.01$ ) (Fig. 3). In the context of this study, overall satisfaction was greater using the Storz VLS (Kruskal-Wallis, $\chi^{2}=56, \mathrm{P}<0.01$ ).

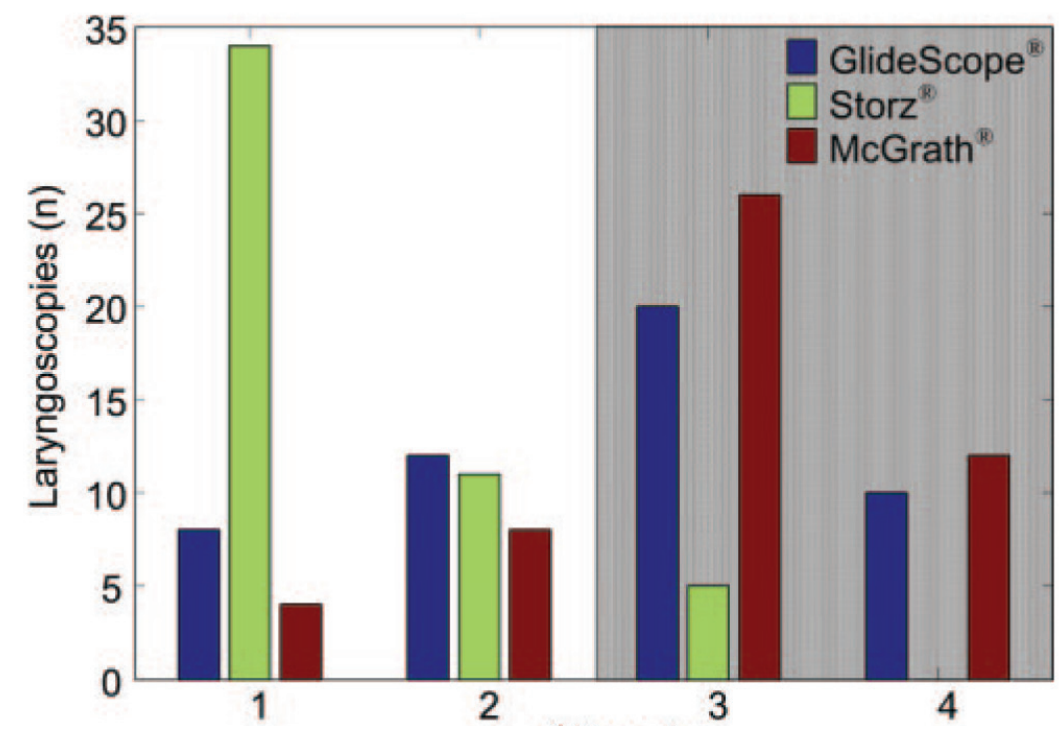

Figure 1. Comparison of number of laryngoscopy attempts for intubation using 3 videolaryngoscopes (VLSs). There are significantly fewer attempts necessary with the Storz ${ }^{\circledR}$ VLS than with both the GlideScope ${ }^{\circledR}$ and $\operatorname{McGrath}^{\circledR}(\mathrm{P}<0.01)$, and fewer attempts necessary with the GlideScope than with the McGrath VLS $(P<0.05)$. 


\section{Discussion}

This study confirms that a styletted ETT is highly desirable to intubate the trachea in morbidly obese patients when certain VLSs are used (e.g., GlideScope and McGrath), whereas with the Storz VLS, the use of a stylet is not essential. This finding is in agreement with our previous study in a group of 450 nonobese adult patients (ASA physical status I-II). ${ }^{7}$ The importance of the VLS in improving intubation conditions in this challenging (and growing) patient population has been shown. ${ }^{3}$ The various VLSs available on the market differ significantly in their ease of use (in terms of intubation time, number of attempts, and the need for additional adjuncts), even when the visual quality is essentially identical.

Table 2. Intubation Metrics

\begin{tabular}{|c|c|c|c|}
\hline Videolaryngoscope & $\begin{array}{c}\text { GlideScope }^{\oplus} \text { Ranger }^{\mathrm{TM}} \\
(n=50)\end{array}$ & $\begin{array}{c}\text { Storz }^{\oplus} \text { V-MAC } \\
(n=50)\end{array}$ & $\begin{array}{c}\text { McGrath }^{\circledR} \text { Series-5 }{ }^{\mathrm{TM}} \\
(n=50)\end{array}$ \\
\hline $\begin{array}{l}\text { Intubation attempts } \\
\text { Mean } \pm \text { sd } \\
1 / 2 / 3 / 2: 4, n(\%)\end{array}$ & $\begin{array}{c}2.6 \pm 1.0^{* *} \\
8 / 12 / 20 / 10 * * \\
(16 / 24 / 40 / 20)\end{array}$ & $\begin{array}{l}1.4 \pm 0.7 * \\
34 / 11 / 5 / 0^{*} \\
(68 / 22 / 10)\end{array}$ & $\begin{array}{c}2.9 \pm 0.9 \\
4 / 8 / 26 / 12 \\
(8 / 16 / 52 / 24)\end{array}$ \\
\hline $\begin{array}{l}\text { Intubation attempts without stylet } \\
\text { One attempt, } n(\%) \\
\text { Two attempts, } n(\%) \\
\text { Total, } n \text { (\% from all subjects) }\end{array}$ & $\begin{array}{l}8(40) \\
12(60) \\
20(40)\end{array}$ & $\begin{array}{l}34(76)^{*} \\
11(24)^{*} \\
45(90)^{*}\end{array}$ & $\begin{array}{l}4(33) \\
8(67) \\
12(24)\end{array}$ \\
\hline $\begin{array}{l}\text { Intubation attempts with stylet } \\
\text { One attempt, } n(\%) \\
\text { More than or equal to two } \\
\text { attempts, } n(\%) \\
\text { Total, } n \text { (\% from all subjects) }\end{array}$ & $\begin{array}{l}20(33) \\
10(67) \\
30(60)\end{array}$ & $\begin{array}{l}5(100) \\
0(0) \\
5(10)\end{array}$ & $\begin{array}{l}26(68) \\
12(32) \\
38(76)\end{array}$ \\
\hline Intubation time, mean $\pm \mathrm{sd}(\mathrm{s})$ & $33 \pm 18^{* *}$ & $17 \pm 9^{*}$ & $41 \pm 25$ \\
\hline $\begin{array}{l}\text { Cormack-Lehane (CL) grade } \\
\text { Classic laryngoscope, CL } \\
\text { mean } \pm \text { sd } \\
\text { Classic laryngoscope, CL } \\
\text { I/II/III/IV, } n \\
\text { VLS, CL mean } \pm \text { sd }\end{array}$ & $\begin{array}{l}2.1 \pm 0.80 \\
11 / 22 / 15 / 2 \\
1.1 \pm 0.24\end{array}$ & $\begin{array}{l}2.0 \pm 0.90 \\
16 / 20 / 11 / 3 \\
1.1 \pm 0.26\end{array}$ & $\begin{array}{l}2.0 \pm 0.83 \\
16 / 20 / 12 / 2 \\
1.1 \pm 0.28\end{array}$ \\
\hline $\begin{array}{l}\text { Overall satisfaction } \\
\text { Good/moderate/fair/poor/ } \\
\text { failure, } n(\%)\end{array}$ & $\begin{array}{l}21 / 28 / 1 / 0 / 0^{* *} \\
(42 / 56 / 2 / 0 / 0)\end{array}$ & $\begin{array}{l}45 / 5 / 0 / 0 / 0 * \\
(90 / 10 / 0 / 0 / 0)\end{array}$ & $\begin{array}{r}11 / 37 / 2 / 0 / 0 \\
(22 / 74 / 4 / 0 / 0)\end{array}$ \\
\hline
\end{tabular}

* Statistically significant difference over other tested videolaryngoscopes $(\mathrm{P}<0.01)$.

** Statistically significant difference over McGrath ${ }^{\circledR}$ VLS $(\mathrm{P}<0.05)$. 


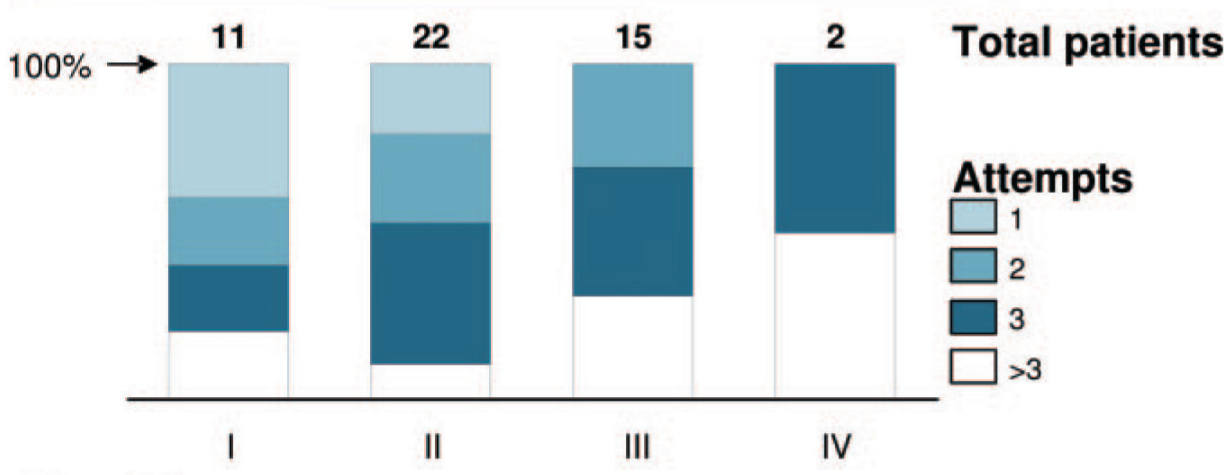

Storz ${ }^{\circledR}$

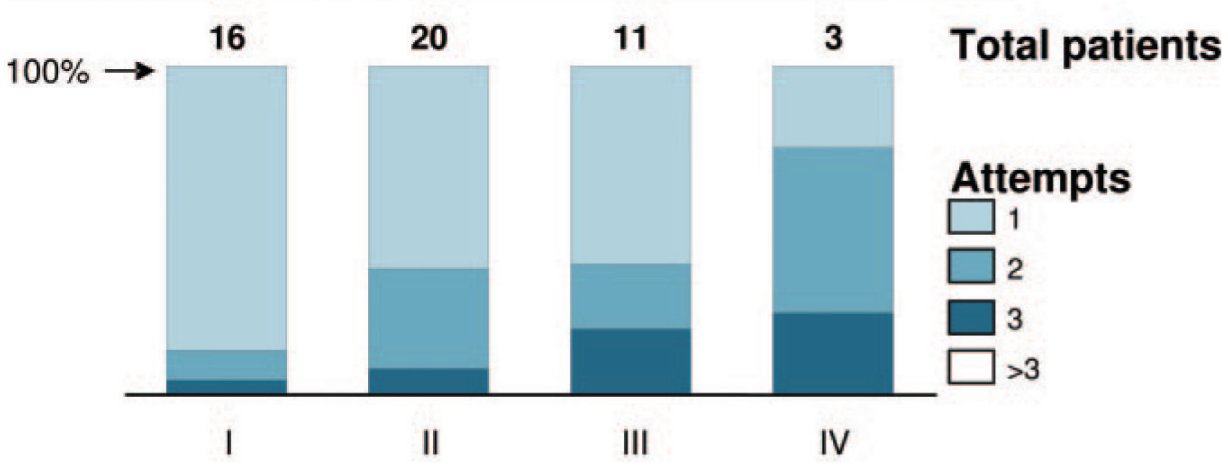

McGrath ®

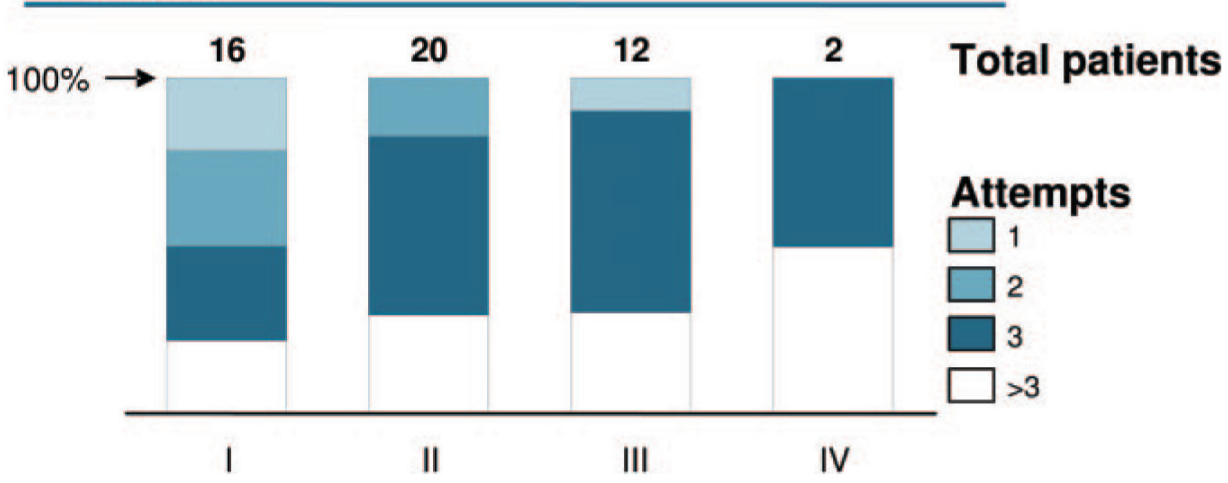

Figure 2. Comparison of required intubation attempts for 3 videolaryngoscopes (VLSs) for Cormack and Lehane $(C \& L)$ grade as assessed with a classic laryngoscope. The Storz ${ }^{\circledR}$ VLS performed better than both the GlideScope $^{\circledR}$ and McGrath ${ }^{\circledR}$ VLSs with fewer attempts required across the spectrum of patient $\mathrm{C} \& \mathrm{~L}$ grades $(\mathrm{P}<0.01) . \mathrm{C} \& \mathrm{~L}$ grade as assessed by classic laryngoscopy was a significant factor in the number of intubation attempts with the different VLSs $(\mathbf{P}<0.01)$. 


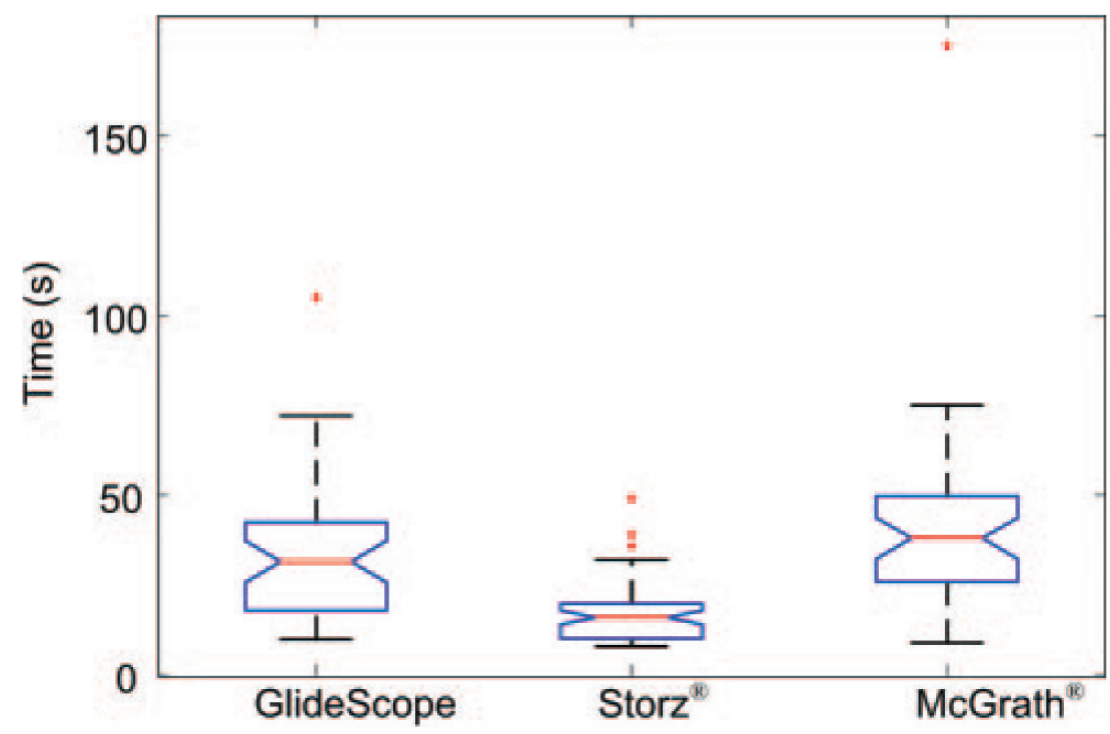

Figure 3. Comparison of required intubation time for 3 videolaryngoscopes (VLSs). Significantly less time was required to intubate with the Storz ${ }^{\circledR}$ VLS than with both the GlideScope ${ }^{\circledR}$ and McGrath $^{\circledR}$ VLSs $(P<0.01)$, and less time necessary with the GlideScope than with the McGrath VLS $(P<0.05)$.

Use of the Storz VLS was associated with shorter intubation time, significantly fewer attempts to secure the airway compared with the other 2 VLS groups, and a need for a stylet in only a minority $(10 \%)$ of the patients, whereas a styletted ETT had to be used in $60 \%$ and $76 \%$ of this patient population in the GlideScope and McGrath VLS groups, respectively. Presumably, this is due to the fact that the Storz VLS uses the same Macintosh laryngoscope blade as with direct laryngoscopy, affording additional room for ETT insertion, and limiting the need for stylet use. The study was not powered to show that any one blade was superior for all respective $\mathrm{C} \& \mathrm{~L}$ grades, and this should be further investigated in subsequent clinical trials. Furthermore, the view provided by the VLS, especially in the case of the GlideScope and the McGrath VLS, does not necessarily correspond with the path followed by the ETT, making the hand-eye coordination exceptionally difficult. Indeed, the hockey stick profile of the stylet is necessary to match the sharp distal curve of the GlideScope and the McGrath VLS. Conceivably, the sharp angle of the GlideScope and McGrath VLSs might be advantageous in patients with difficult anatomy, such as micrognathia, neck immobility, or sublingual tonsillar hypertrophy. 
We used a very stringent definition of an intubation attempt as the number of intubation attempts was counted as each approach of the ETT to the glottic entrance, even without complete withdrawal of the ETT out of the mouth. This strict criterion certainly influenced the observation that half of all patients required 3 or more intubation attempts. The ETT usually followed a path more dorsal to the view provided by the VLS. In other words, the view that is provided by the sharply curved VLS is not the same as the path of the less curved ETT (without stylet).

In direct laryngoscopy, a stylet is an adjunct rarely used at first attempt in our clinical practice. Given the fact that styletted ETTs have rare but potentially important complications with videolaryngoscopy [6, 8-16], but also when direct laryngoscopy with a classic Macintosh blade is used [19-22], we believe it is important to reserve the use of a stylet for difficult intubations. Morbidly obese patients are rarely "routine" in their intubation requirements. However, morbid obesity does not automatically portend a difficult airway, and metrics that only consider macro patient characteristics are incomplete at best and less relevant to videolaryngoscopy [23]. Besides often having more difficult airways, the time pressure is also greater, because desaturation develops more quickly in obese than in nonobese patients $[24,25]$. Less routine use of a stylet for some VLSs does not imply that intubation adjuncts, such as a stylet or a difficult airway/ intubation cart, should be not readily at hand for unanticipated difficult intubations.

This study has several limitations as follows: 1) The attending anesthesiologist was not blinded to the type of VLS used, which may have introduced slight bias, although the anesthesiologist was blinded to the preoperative metrics and initial C\&L grade with the use of the classic Macintosh laryngoscope; 2) Failure to routinely use a stylet may have biased our study in favor of a device that most closely resembles a conventional Macintosh laryngoscope; 3) There are still other VLSs available on the market, so this review is not complete, but 3 of the most common manufacturers (as available in our hospital) were included; 4) Our study group consisted of morbidly obese patients, of which certainly a portion could be intubated easily by conventional direct laryngoscopy, because morbid obesity does not automatically define a population of difficult intubation patients; 5) Although we used the GlideScope stylet ( $90^{\circ}$ angle) as our standard adjunct if intubation failed after 2 attempts, other shapes of stylets can be superior for one or more of the VLSs studied; and 6) Other intubation adjuncts were not studied and could have influenced the results in this study. 


\section{Conclusion}

Videolaryngoscopy offers superior viewing of the glottis, which can be problematic in morbidly obese patients. However, the VLSs available on the market differ significantly in their ease of use, even when the visual quality is essentially identical. In this study, the Storz VLS performed better in overall satisfaction, intubation time, number of intubation attempts, and necessity of extra adjuncts, compared with the other 2 devices. Furthermore, successful intubation (without using a stylet) in the Storz group was 90\%, supporting our hypothesis that a stylet may not be needed at all times when using a VLS, therefore preventing potential complications. A good view of the glottis is important but not alone sufficient. The interaction of the blade with the ETT is similarly critical and seems to be the remaining obstacle in developing an optimal laryngoscope design.

\section{Acknowledgments}

The videolaryngoscopes were made available to the study center, on a temporary basis, at no cost by the respective manufacturers: Ranger ${ }^{\mathrm{TM}}$ GlideScope $^{\circledR}$, Verathon Inc., Bothell, WA; V-Mac ${ }^{\text {TM }}$ Storz ${ }^{\circledR}$ Macintosh, Karl Storz, Tuttlingen, Germany; and McGrath ${ }^{\circledR}$ Series 5, Aircraft Medical, Edinburgh, United Kingdom.

\section{References}

1. Gonzalez H, Minville V, Delanoue K, Mazerolles M, Concina D, Fourcade O. The importance of increased neck circumference to intubation difficulties in obese patients. Anesth Analg 2008; 106:1132-6.

2. Juvin P, Lavaut E, Dupont H, Lefevre P, Demetriou M, Dumou- lin JL, Desmonts JM. Difficult tracheal intubation is more com- mon in obese than in lean patients. Anesth Analg 2003; 97: 595-600.

3. Marrel J, Blanc C, Frascarolo P, Magnusson L. Videolaryngos- copy improves intubation conditions in morbidly obese pa- tients. Eur J Anaesthesiol 2007; 24: 1045-9.

4. Shippey B, Ray D, McKeown D. Case series: the McGrath videolaryngoscope-an initial clinical evaluation. Can J Anaesth 2007;54:307-13 5. Shippey B, Ray D, McKeown D. Use of the McGrath videolaryn- goscope in the management of difficult and failed tracheal intubation. Br J Anaesth 2008; 100: 116-9.

6. Vincent RD Jr, Wimberly MP, Brockwell RC, Magnuson JS. Soft palate perforation during orotracheal intubation facilitated by the GlideScope videolaryngoscope. J Clin Anesth 2007;19: 619-21.

7. Van Zundert A, Maassen R, Lee R, Willems R, Timmerman M, Siemonsma M, Buise M, Wiepking M. A Macintosh laryngo- scope blade for videolaryngoscopy reduces stylet use in patients with normal airways. Anesth Analg 2009; 109: 825-31.

8. Choo MK, Yeo VS, See JJ. Another complication associated with videolaryngoscopy. Can J Anaesth 2007; 54: $322-4$. 
9. Cooper RM. Complications associated with the use of the GlideScope videolaryngoscope. Can J Anaesth 2007; 54: 54-7.

10. Hirabayashi Y. Pharyngeal injury related to GlideScope videolaryngoscope. Otolaryngol Head Neck Surg 2007; 137: $175-6$.

11. Hsu WT, Hsu SC, Lee YL, Huang JS, Chen CL. Penetrating injury of the soft palate during GlideScope intubation. Anesth Analg 2007;104:1609-10.

12. Hsu WT, Tsao SL, Chen KY, Chou WK. Penetrating injury of the palatoglossal arch associated with use of the GlideScope videolaryngoscope in a flame burn patient. Acta Anaesthesiol Taiwan 2008; 46: 39-41.

13. Malik AM, Frogel JK. Anterior tonsillar pillar perforation dur- ing GlideScope video laryngoscopy. Anesth Analg 2007; 104: 1610 -1.

14. Cross P, Cytryn J, Cheng KK. Perforation of the soft palate using the GlideScope videolaryngoscope. Can J Anaesth 2007; 54: 588 -9,

15. Manickam BP, Adhikary SD. Soft palate perforation during orotracheal intubation facilitated by the GlideScope videolaryn- goscope. J Clin Anesth 2008; 20: 401-3.

16. Leong WL, Lim Y, Sia AT. Palatopharyngeal wall perforation during GlideScope intubation. Anaesth Intensive Care 2008; 36: 870-4.

17. Doyle DJ. The GlideScope video laryngoscope. Anaesthesia 2005; 60: 414-5

18. Jones PM, Turkstra TP, Armstrong KP, Armstrong PM, Cherry RA, Hoogstra J, Harle CC. Effect of stylet angulation and endotracheal tube camber on time to intubation with the GlideScope. Can J Anaesth 2007; 54 : 21-7.

19. Chen EH, Logman ZM, Glass PSA, Bilfinger TV. A case of tracheal injury after emergent endotracheal intubation: a review of the literature and causalities. Anesth Analg 2001; 93: 1270-1.

20. Besmer I, Schu“ pfer G, Stulz P, Jöhr M. [Tracheal rupture: delayed diagnosis with endobronchial intubation]. Anaesthesist 2001; 50: 167-70.

21. Moschini V, Losappio S, Dabrowska D, Iorno V. Tracheal rupture after tracheal intubation: effectiveness of conservative treatment. Minerva Anestesiol 2006; 72: 1007-12.

22. Fan CM, Ko PC, Chiang WC, chang YC, Chen WJ, Yuan A. Tracheal rupture complicating emergent endotracheal intubation. Am J Emerg Med 2004; 22: 289-93.

23. Van Zundert A, Lee R. Intubation difficulties in obese patients. Anesth Analg 2009; 108: 1051-2.

24. Benumof J, Dagg R, Benumof R. Critical hemoglobin desatura- tion will occur before return to an unparalyzed state following $1 \mathrm{mg} / \mathrm{kg}$ intravenous succinylcholine. Anesthesiology 1997; 87: 979-82.

25. Jense HG, Dubin SA, Silverstein PI, O'Leary-Escholas U. Effect of obesity on safe duration of apnea in anesthetized humans. Anesth Analg 1991; 72: 89 -93. 


\section{Chapter 6}

doi: 10.1111/j.1365-2044.2010.06464.x

\section{Comparison of the $\mathrm{C}$-MAC ${ }^{\circledR}$ videolaryngoscope with the Macintosh, Glidescope ${ }^{\circledR}$ and Airtraq ${ }^{\circledR}$ laryngoscopes in easy and difficult laryngoscopy scenarios in manikins}

R. Maassen, A. van Zundert

\section{Anaesthesia}

Journal of the Association of Anaesthetists of Great Britain and Ireland

Catharina Hospital, Brabant Medical School, Eindhoven, The Netherlands

Email: ralph.maassen@planet.nl

No external funding and no competing interests declared.

Previously posted at the Anaesthesia Correspondence website: http://www.anaes thesiacorrespondence.com. 


\section{Letter-to-the Editor}

We read the manikin study of McElwain et al. [1] with great interest. However, we disagree with their conclusion that evaluation of videolaryngoscopes in the clinical setting receives little if any independent evaluation.

The results of their manikin study are congruent to several studies we have published [2-4], in which we clinically tested the performance of the following three videolaryngoscopes: GlideScope $^{\circledR}$ (RangerTM; Verathon Inc, Bothell, WA, USA); V-MACTM Storz ${ }^{\circledR}$ Berci DCI $^{\circledR}$ (Karl Storz, Tuttlingen, Germany); and McGrath ${ }^{\circledR}$ (McGrathTM Series 5; Aircraft Medical, Edinburgh, UK). Our findings showed better clinical performance in normal [2] and difficult airways [3] and less need for adjuncts (e.g. stylet), with videolaryngoscopy using a Macintosh type blade compared with the other videolaryngoscopes tested. Additionally, we showed reduced forces on the upper teeth during intubation using videolaryngoscopy incorporating a Macintosh type blade when compared to direct laryngoscopy [4, 5].

The finding that the Glidescope ${ }^{\circledR}$ performed least well in McElwain's manikin study did not surprise us at all, and confirms what we experienced in clinical practice.

\section{A reply}

We would like to thank Drs Maassen and van Zundert for their interesting comments regarding our paper [1] and welcome the opportunity to respond. We respectfully suggest that the authors may have misinterpreted our comments, which were not conclusions, but rather a statement in the early part of the discussion outlining the rationale for these studies. The point we made was that many novel videolaryngoscopes receive little or no independent evaluation before being introduced into clinical practice, a point also made by other authors [2]. As we stated in the paper, the need to determine the clinical utility of these devices, ideally before their widespread adoption into clinical practice, is clear if we are to avoid a situation where a poorly designed device contributes to the failure to perform tracheal intubation, leading to patient harm. 


\section{References}

1, McElwain J, Malik MA, Harte BH, Flynn NM, Laffey JG. Comparison of the C-MAC ${ }^{\circledR}$ videolaryngoscope with the Macintosh, Glidescope ${ }^{\circledR}$, and Airtraq $^{\circledR}$ laryngoscopes in easy and difficult laryngoscopy scenarios in manikins. Anaesthesia 2010; 65: 483-9.

2. Van Zundert A, Maassen R, Lee R, et al. A Macintosh laryngoscope blade for videolaryngoscopy reduces stylet use in patients with normal airways. Anesthesia and Analgesia 2009; 109: 825-31.

3. Maassen R, Lee R, Hermans B, Marcus M, van Zundert A. A comparison of three videolaryngoscopes: the Macintosh blade reduces, but does not replace, routine stylet use for intubation in morbidly obese patients. Anesthesia and Analgesia 2009; 109: 1560-5.

4. Maassen R, Lee R, van Zundert A, Cooper R. The videolaryngoscope is less traumatic than the classic laryngoscope for a difficult airway in an obese patient. Journal of Anesthesia 2009; 23: 445-8.

5. Lee RA, Zundert AA, Maassen RL, et al. Forces applied to the maxillary incisors during video-assisted intubation. Anesthesia and Analgesia 2009; 108: 187-91. 
(Acta Anaesth. Belg., 2012, 63, 181-186)

\title{
Endotracheal intubation using videolaryngoscopy causes less cardiovascular response compared to classic direct laryngoscopy, in cardiac patients according a standard hospital protocol
}

\author{
R.L.J.G. Maassen¹, B.M.A. Pieters², B. Maathuis ${ }^{3}$, J. Serroyen ${ }^{4}$, M.A.E. Marcus ${ }^{5}$, \\ P. Wouters ${ }^{6}$ and A.A.J. van Zundert ${ }^{7}$
}

Ralph L.J.G. Maassen, Anaesthesiologist, M.D.; Barbe M.A. Pieters, Resident in Anaesthesiology, M.D.; Brando Maathuis, Bachelor of Science; Jan Serroyen, Assistant Professor, Ph.D.; Marco A.E. Marcus, Professor of Anaesthesiology, M.D., Ph.D.; Patrick Wouters, Professor of Anaesthesiology, M.D., Ph.D.; André A.J. van Zundert, Professor of Anaesthesiology, M.D., Ph.D., F.R.C.A., E.D.R.A., F.A.N.Z.C.A.

1 Departments of Anaesthesiology Catharina Hospital, Eindhoven, Netherlands \& University Hospital Maastricht, the Netherlands.

2 Department of Anaesthesiology University Hospital Maastricht, the Netherlands.

3 Department of Biomechanical Engineering, Mechanical, Materials and Maritime Engineering, Delft University of Technology, Delft, the Netherlands.

${ }^{4}$ Department of Methodology and Statistics. CAPHRI. Maastricht University, the Netherlands.

5 Department of Anaesthesiology University Hospital Maastricht, the Netherlands.

${ }^{6}$ Department of Anaesthesiology, Ghent University Hospital, Ghent, Belgium.

7 Department of Anesthesiology, Intensive Care and Pain Therapy, Catharina Hospital - Brabant Medical School, Eindhoven and Maastricht University, the Netherlands \& Ghent University Hospital, Ghent, Belgium.

Corresponding author: Prof. Dr. André van Zundert, Department of Anesthesiology, Intensive Care and Pain Therapy, Catharina Hospital - Brabant Medical School, Michelangelolaan 2, NL-5623 EJ Eindhoven, The Netherlands.

Tel. : + 3140 2399111. Fax : + 3140 2463978. E-mail : zundert@iae.nl 


\section{Abstract}

Introduction: Previous studies comparing Glidescope and classic direct laryngoscopy did not show an attenuation of $\mathrm{CV}$ responses to endotracheal intubation. In the present study, we hypothesize that indirect videolaryngoscopy can attenuate cardiovascular responses to endotracheal intubation.

Methods: In a randomized cross-over study, eighty adults (ASA PS II-III) were included.

Both direct and indirect videolaryngoscopies were used in a random order, in the same patient. Cardiovascular responses to intubation were recorded as a relative change in rate pressure product (RPP = systolic blood pressure times heart rate) from baseline values.

A linear mixed model was used to study the association between the outcome variable RPP and the type of laryngoscope used.

Results: The relative increase of the RPP at intubation was significantly smaller (i.e. $27 \%$, $\mathrm{P}<0.001)$ using videolaryngoscopy compared to the classic direct laryngoscopy.

Cardiovascular responses were blunted by an additional 10.2\% ( $\mathrm{P}=0.029)$, when the patient was on beta blockade.

Conclusions: Our study shows less hemodynamic responses during endotracheal intubation using indirect videolaryngoscopy compared to classic direct laryngoscopy.

Key words: Cardiovascular responses, videolaryngoscopy, classic laryngoscopy.

\section{Introduction}

Cardiovascular responses to endotracheal intubation have been well documented for direct laryngoscopy and are caused by the noxious stimuli to the oropharyngeal structures (laryngoscopy) and the larynx and trachea (exerted by the tracheal tube insertion) [1] Previous studies showed diminished cardiovascular responses to endotracheal intubation after beta blocker therapy [2].The improved glottic view provided by indirect videolaryngoscopy reduces the need for excessive force on the laryngoscope [3].

A comparison of the cardiovascular responses to endotracheal intubation using both indirect videolaryngoscopy and direct laryngoscopy within the same patient has not yet been described.

The primary goal of this randomized cross-over study is to determine whether there is a difference between cardiovascular responses to endotracheal intubation using direct laryngoscopy compared to indirect videolaryngoscopy. Secondly, we tested cardiovascular responses in patients with and without beta-blocker therapy. 


\section{Introduction}

We hypothesized that there would be diminished cardiovascular responses to endotracheal intubation when using indirect videolaryngoscopy compared to direct classic laryngoscopy. Additionally, we hypothesized that diminished cardiovascular responses during videolaryngoscopy might not be seen in patients on beta-blocker therapy, as these patients already have diminished responses to endotracheal intubation.

\section{Methods}

Study design

We performed a randomized cross-over study, in which each patient received sequential treatments in a random order (intubation with direct and indirect laryngoscopy), separated by a washout period. Each patient is able to act as his or her own control and permits between and within group comparisons [4]. To prevent carry-over effect, the washout period in this study was three minutes, based on a pilot study.

\section{In- and exclusion criteria}

After approval by the hospital medical ethics committee (Catharina Hospital Eindhoven, the Netherlands) and obtaining informed consent, 80 adult patients (ASA physical status II-III), scheduled for elective coronary artery bypass surgery requiring endotracheal intubation and intra-arterial blood pressure monitoring, were included in this study (JanuaryJune 2010).

The preanesthetic visit (performed by an anaesthesiologist not involved in this study) ascertained history of difficult intubation, measurement of common predictive indices for difficult intubation (BMI, thyromental distance, Mallampati grade, interincisal (or intergingival) distances), and evaluation of status of dentition and neck mobility.

We excluded patients who were obese $\left(\mathrm{BMI}>35 \mathrm{~kg} / \mathrm{m}^{2}\right)$; who had chronic obstructive pulmonary disease ; who had a history of difficult intubation; a mouth opening $<3 \mathrm{~cm}$, inadequate neck mobility or if the patient had a left ventricular ejection fraction (LVEF) $<45 \%$.

All patients were fasted overnight and were restricted to oral intake of clear fluid for two to three hours before operation. Medications were continued until the morning of surgery, except angiotensin-converting enzyme inhibitors. Premedication was administered, using oral midazolam $0.1 \mathrm{mg} / \mathrm{kg}$ (maximum $7.5 \mathrm{mg}$ ) one hour before induction. 


\section{Monitoring}

After arrival of the patient in the operating theatre, standard monitoring was attached using a pulse oximeter, a five-lead ECG and bispectral index monitoring (BIS), using a multifunction monitor (Datex Ohmeda F-CU 8 ; Datex instrumentarium Helsinki, Finland).

ST segment analysis (leads II and V) was performed, using standard criteria for myocardial ischemia [5]. Well before induction of anesthesia the patient received a standard 18 gauge intravenous cannula and an intra-arterial cannula. A stabilisation period of three minutes was allowed to acquire patient's actual blood pressure values.

\section{Laryngoscopy}

All patients underwent endotracheal intubation using both the classic (direct) laryngoscope and the indirect videolaryngoscope in a random order, separated by a washout period of three minutes.

\section{Intra-procedural metrics}

During intubation, intra-procedural metrics of intubation difficulty (Cormack-Lehane grade) were measured, as well as our dependent parameters of effective airway time, number of attempts, and use of extra adjuncts to facilitate intubation. The need for extra maneuvers to optimize the visualization of the glottis entrance (e.g. backward upward rightward pressure (BURP)) was also recorded. The number of intubation attempts was counted as each approach of the endotracheal tube (ETT) to the glottis entrance. If after two attempts the patient still could not be intubated, a stylet or gum elastic bougie was used to facilitate intubation.

Effective airway time, using a stopwatch, was measured (by an assistant) as the time between picking up the ETT (Hi-contour ${ }^{\mathrm{TM}}$, Mallincrodt Medical, Athlone, Ireland) and the visual passage of the tube until the vocal cords were between the two black line markings on the distal end of the ETT. Interim bag and mask time, if needed, was not included in the effective airway time. Patients requiring an effective airway time of more than two minutes, were excluded from statistical analysis of data.

\section{Anesthesia \& hemodynamic measurements}

Following a three minutes stabilization period, with the patient positioned horizontally, systolic blood pressure (SBP), diastolic blood pressure (DBP), mean arterial pressure (MAP) and heart rate (HR) were obtained. Patients were randomly allocated to receive first either direct Macintosh laryngoscopy or indirect videolaryngoscopy (VLS), using the C-Mac ${ }^{\mathrm{TM}}$ Storz $^{\circledR}$ (Karl Storz, Tuttlingen, Germany) by selecting a sealed card. 
Anesthesia was induced, after routine preoxygenation, with fentanyl $5 \mu \mathrm{g} / \mathrm{kg}$ i.v., followed by etomidate $0,3 \mathrm{mg} / \mathrm{kg}$ and rocuronium $1 \mathrm{mg} / \mathrm{kg}$ based on lean body mass, followed by $2 \%$ sevoflurane in oxygen. Three minutes after administering rocuronium, adequate neuromuscular relaxation was tested using train of four (TOF)-monitoring.

Subsequently, the ETT was inserted, using both direct laryngoscopy and indirect videolaryngoscopy in a random order. Measurements were taken during the first endotracheal intubation, without inflating the cuff of the ETT. Subsequently, the ETT was withdrawn and the patient was mask ventilated with sevoflurane $2 \%$ for a stabilization (washout) period of three minutes. The follow-up measurements were taken at one and three minutes after withdrawal of the ETT and new baseline values were obtained. Then, the second endotracheal intubation was carried out, including inflation of the cuff of the ETT. Again hemodynamic measurements were obtained at intubation (before inflation of the cuff) and at one and three minutes after endotracheal intubation.

The bispectral index (BIS) values were kept between 40 and 50 (on average 45), to standardize the depth of anesthesia and $2 \%$ sevoflurane in oxygen was added if needed.

Cardiovascular responses to intubation were calculated as a relative change in rate pressure product $(\mathrm{RPP}=$ systolic blood pressure times heart rate) from baseline values.

Anesthesia was maintained with sevoflurane $2 \%$ in oxygen. The ventilator settings were adjusted to maintain the end tidal CO2 level between 4,5 $\mathrm{kPa}$ and 5,2 $\mathrm{kPa}$.

Postoperative care was given at the postoperative anesthesia care unit (PACU). Within two weeks after surgery, an independent operator interviewed all patients using a standard questionnaire. We assessed whether, and to which extent, the patients complained of a sore throat postoperatively.

\section{Statistics}

A linear mixed model was used to study the association between the outcome variable RPP and the type of laryngoscope used. The linear mixed model enabled us to extend the classical cross-over analysis and allowed us to correct for additional covariates (i.e., beta blocker administration and effective airway time). P-values less than 0.05 were considered as statistically significant.

To achieve a significance level (alpha) of 0.05 , a power of $95 \%$, a standard error of $8 \%$ and a response difference in RPP from 15 to $20 \%$ between both devices, we calculated a sample size of 72 patients. The calculated standard error was based on a pilot study of 20 patients. We included 80 patients.

All statistical analyses were performed using SAS ${ }^{\circledR}$ (SAS Institute Inc. Cary, NC, USA) version 9.2. 


\section{Results}

A total of 80 patients, of whom 48 were on beta-blocker therapy, were included in this study, and all were successfully intubated using both indirect videolaryngoscopy and direct classic laryngoscopy, without adverse events. No patients were excluded from analysis because of prolonged effective airway time.

Patient characteristics and pre-procedural intubation conditions did not differ substantially between patients (Table 1). Peripheral oxygen saturation was maintained above $95 \%$ in all patients throughout the laryngoscopy and intubation period. We did not detect any injury of the palatoglossal arch or dental injury in any of the patients. Only three patients, who had an effective airway time of more than 50 seconds, reported postoperatively minor, selflimiting sore throat complaints, which did not require any treatment. No signs of myocardial ischemia were seen on the ECG during induction or recovery. The effective airway time was significantly longer when using classic laryngoscopy $(10.3 \pm 13.8 \mathrm{~s})$ compared to videolaryngoscopy $(6.1 \pm 5.9 \mathrm{~s}, \mathrm{P}=0.002)$. There was no significant correlation between effective airway time and RPP after correction for laryngoscope type and beta blocker effect.

The relative increase of the RPP at intubation was significantly smaller (i.e. $27 \%$, $\mathrm{P}<0.001$ ) using videolaryngoscopy compared to the classic direct laryngoscopy.

Cardiovascular responses were blunted by an additional 10.2\% $(\mathrm{P}=0.029)$, when the patient was on beta blockade (Fig. 1).

Based on mean RPP values (Table 2), maximal values of RPP during observation increased by $48.3 \%$ and $189 \%$ of their baseline values during indirect videolaryngoscopy and direct classic laryngoscopy, respectively. Table 2 shows the mean RPP values for the different measurement occasions within the different groups (i.e. classic laryngoscope and VLS with and without beta blockade).

Table 1. Patient characteristics, pre- and intraprocedural intubation conditions

\begin{tabular}{|l|l|}
\hline & Incidence $n=80$ \\
\hline Male: female, $n(\%)$ & $55: 25(69: 31)$ \\
\hline Age, yrs & $66.2 \pm 10.2$ \\
\hline Weight, $\mathrm{kg}$ & $80.9 \pm 15.5$ \\
\hline Height, $\mathrm{cm}$ & $172 \pm 9$ \\
\hline ASA physical status; I:II:III:IV, $n(\%)$ & $0: 67: 13: 0(0: 84: 16: 0)$ \\
\hline Body mass index, kg.m- ${ }^{2}$ & $27.0 \pm 4$ \\
\hline Thyromental distance, $\mathrm{mm}$ & $77.8 \pm 8$ \\
\hline Mallampati grade; I:II:III:IV, $n(\%)$ & $34: 41: 5: 0(43: 51: 6: 0)$ \\
\hline Dentition; full dentures:single:none, $n(\%)$ & $32: 6: 42(40: 7.5: 52.5)$ \\
\hline
\end{tabular}

Data are reported as $n(\%)$, or mean $\pm \mathrm{SD}$. 


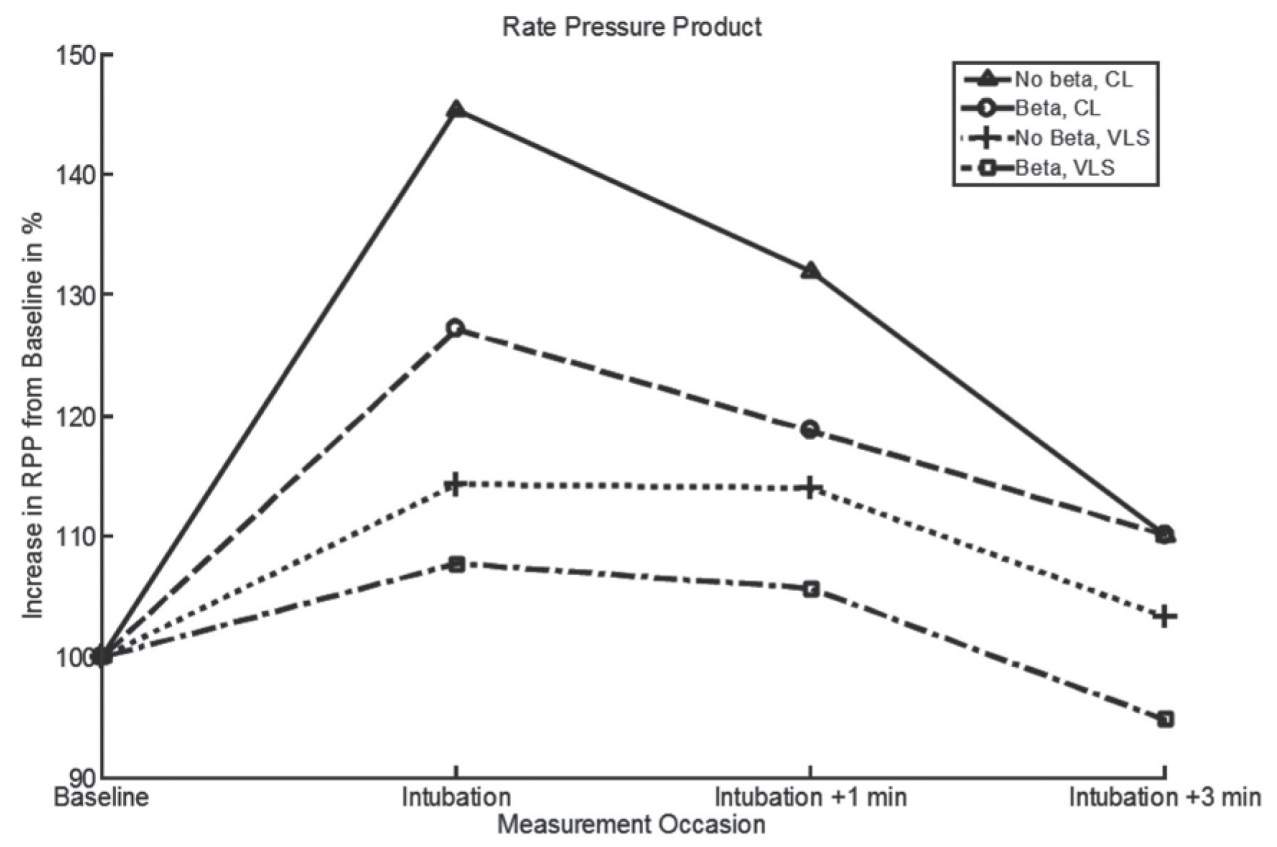

Figure 1. Relative change in Rate Pressure Product (RPP) from baseline. Following intubation a peak in RPP is seen with direct and indirect videolaryngoscopy, with a diminished peak at intubation when using the videolarygoscope (VLS) compared to direct (classic) laryngoscopy (CL) for both patients with (Beta) and without beta blockade (No beta).

\section{Discussion}

This study clearly demonstrated less cardiovascular responses to endotracheal intubation using indirect (Macintosh) videolaryngoscopy, compared to direct (classic) laryngoscopy.

Direct laryngoscopy and endotracheal intubation affect the cardiovascular system and lead to an average increase in blood pressure by $40-50 \%$ and $20 \%$ increase in heart rate [6]. It has been demonstrated that cardiovascular responses can be attenuated by betablockers [2]. Studies [7,8] that investigated cardiovascular responses to endotracheal intubation, comparing direct laryngoscopy and indirect videolaryngoscopy with the use of the Glidescope ${ }^{\circledR}$, were not able to show an attenuation of the cardiovascular responses when videolaryngoscopy was used. The GlideScope ${ }^{\circledR}$ videolaryngoscope offers an excellent view of the glottis, but intubation is not always straightforward. The use of a stylet with a relatively pronounced curve (the best angle is reported to be $90^{\circ}$ ) $[9,10]$ at the distal end is the most helpful and needed in the majority of the cases in order to advance the tip of the ETT to the glottic opening [11]. Stylet use goes hand in hand with more manipulations and increases the potential noxious stimulation to the trachea, which can provoke cardiovascular responses. 
Table 2. Mean RPP values for the different measurement occasions

\begin{tabular}{|l|c|c|c|c|}
\hline Measurement Occasion & No Beta CL & Beta CL & No Beta VLS & Beta VLS \\
\hline Baseline & $7638 \pm 1873$ & $6663 \pm 1632$ & $7777 \pm 1852$ & $7284 \pm 1883$ \\
\hline Intubation & $11022 \pm 3400$ & $8529 \pm 3078$ & $8953 \pm 2782$ & $7834 \pm 2236$ \\
\hline Intubation + 1 min & $9869 \pm 2853$ & $7939 \pm 2569$ & $8901 \pm 3038$ & $7725 \pm 2668$ \\
\hline Intubation + 3 min & $8220 \pm 1863$ & $7246 \pm 2052$ & $7992 \pm 2254$ & $6847 \pm 2181$ \\
\hline
\end{tabular}

Mean RPP values $( \pm$ SD) for the different measurement occasions within the different groups (i.e. classic laryngoscope and videolaryngoscope with and without beta blockade).

Previous studies [11,12] demonstrated that clinical differences do exist between different brands of videolaryngoscopes and found that a Macintosh blade results in better intubation scores and less need for a styletted ETT than videolaryngoscopes which use other than Macintosh blades. In our study we therefore used the Storz ${ }^{\circledR}$ C-MAC videolaryngoscope which incorporates a Macintosh blade.

By testing the cardiovascular response curve for both devices - in a random order - within the same patient (cross-over design), we were able to register and compare hemodynamic responses within the same experimental environment and minimized confounding factors (e.g. medication use) which itself could influence the cardiovascular response curve.

RPP (= systolic blood pressure times heart rate) is an index of myocardial oxygen consumption [13]. A RPP of 22,000 is commonly associated with myocardial ischemia [14]. Our results showed that although the maximal values of RPP during observation increased by $48.3 \%$ and $189 \%$ of their baseline values during indirect videolaryngoscopy and direct classic laryngoscopy, respectively, they never exceeded 22,000 in our study.

Takahashi and colleagues concluded that hemodynamic changes following endotracheal intubation are likely to occur because of direct tracheal irritation rather than stimulation of the larynx [15]. In our study both indirect videolaryngoscopy and direct laryngoscopy were performed in a random order, followed by endotracheal intubation. We showed less cardiovascular responses to endotracheal intubation using indirect videolaryngoscopy, compared to direct (classic) laryngoscopy. This implicates that laryngeal stimulation might play a greater role in cardiovascular responses to endotracheal intubation than suggested in the literature. 
This study has several limitations :

1) the attending anaesthesiologist was not blinded to the type of laryngoscope used, although the order of use (indirect videolaryngoscopy or direct laryngoscopy) was randomized ;

2) the observer recording time to intubation and the RPP were not blinded ;

3) beta-blocked and non-beta-blocked patients in the conventional laryngoscopy group did not re-achieve their pre-intubation baseline values, while those in the videolaryngoscope group did (Fig. 1). This could potentially affect the results of the group having undergone direct laryngoscopy first $(n=42)$. This group may have been limited as to the maximal RPP obtainable if they started the second period at a higher HR/SBP than those who underwent videolaryngoscopy first $(n=38)$;

4) the protocol (e.g. drugs and doses) applied, is our own protocol in cardiac anaesthesia, which may be different in other institutions ;

5) this study restricts itself by using only one type videolaryngoscope, and therefore cannot give any conclusion about the results in other VLS. More studies with other videolaryngoscopes are needed to confirm whether a Macintosh blade shows superiority over other blades.

Evidence suggests that the Macintosh VLS has several advantages above direct classic laryngoscopy [3,11,12]. Additionally, this study clearly demonstrates less cardiovascular responses to endotracheal intubation when using Macintosh videolaryngoscopy (even in patients on betablockade).

Although it has been shown recently that cardiovascular responses to laryngoscopy and tracheal intubation - in patients with and without beta blockade - were not associated with cardiac ischaemia (as assessed by ST-segment monitoring) [16], specific conditions (e.g. intracranial hypertension, cerebral aneurysms, large aortic aneurysms, cardiac ischemia or recent myocardial infarction) benefit from anaesthetic management diminishing the cardiovascular responses to laryngoscopy and intubation [17]. Macintosh videolaryngoscopy seems to be contributory to achieve this.

\section{Conclusion}

Our study provides evidence of less hemodynamic responses during endotracheal intubation using indirect videolaryngoscopy incorporating a Macintosh blade compared to classic direct laryngoscopy.

Even if the patient is on beta-blocker therapy, diminished cardiovascular responses at intubation are recorded after indirect laryngoscopy compared to direct laryngoscopy. 


\section{References}

1. Shribman A. J., Smith G., Achola K. J., Cardiovascular and catecholamine responses to laryngoscopy with and without tracheal intubation, Br. J. anaesth., 59, 295-9, 1987.

2. Vucevic M., Purdy G. M., Ellis F. R., Esmolol hydrochloride for the management of the cardiovascular stress responses to laryngoscopy and tracheal intubation, Br. J. anaesth., 68, 529-30, 1992.

3. Lee R. A., van Zundert A. A. J., Maassen R. L., Willems R. J., Beeke L. P., Schaaper J.N., van Dobbelsteen J., Wieringa P. A., Forces applied to the maxillary incisors during video-assisted intubation, Anesth. anaLG., 108, 187-91, 2009.

4. Elbourne D.R., Altman D. G., Higgins J. P. T., Curtin F., Worthington H. V., Vail A., Meta-analyses involving cross-over trials : methodological issues, int. J. ePid., 31, 140-149, 2002.

5. Knight A. A., Hollenberg M., London M. J., Tubau J., Verrier E., Browner W., Mangano D. T., Perioperative myocardial ischemia : Importance of the preoperative ischemic pattern, anesthesioLoGy, 68, 668-70, 1988.

6. Bruder N., Granthil C., Ortega D., Consequenses and prevention methods of hemodynamic changes during laryngoscopy and intubation, ann. Fr. anaesth. reaniM., 11, 57-71, 1992.

7. Siddiqui N., Katznelson R., Friedman Z., Heart rate/blood pressure response and airway morbidity following tracheal intubation with direct laryngoscopy, GlideScope and Trachlight : a randomized control trial. eur. J. anaesth., 26, 740-5, 2009.

8. Xue F. S., Zhang G.H., Li X. Y., Sun H. T., Li P., Li C. W., Liu K. P., Comparison of hemodynamic responses to orotracheal intubation with the GlideScope videolaryngoscope and the Macintosh direct laryngoscope, J. cLin. anesth., 19, 245-50, 2007.

9. Turkstra T.P., Harle C.C., Armstrong K. P., Armstrong P.M., Cherry R.A., Hoogstra J., Jones P.M., The GlideScope-specific rigid stylet and standard malleable stylet are equally effective for GlideScope use, can. J. anesth., 54, 891-6, 2007.

10. Jones P.M., Turkstra T.P., Armstrong K.P., Armstrong P.M., Cherry R.A., Hoogstra J., Harle C.C., Effect of stylet angulation and endotracheal tube camber on time to intubation with the GlideScope, can. J. anesth., 54, 21-7, 2007.

11. Van Zundert A., Maassen R., Lee R., Willems R., Timmerman M., Siemonsma M., Buise M., Wiepking M., A Macintosh laryngoscope blade for videolaryngoscopy reduces stylet use in patients with normal airways, Anesth. anaLG., 109, 825-31, 2009.

12. Maassen R., Lee R., Hermans B., Marcus M., van Zundert A.,A comparison of three videolaryngoscopes: the Macintosh blade reduces, but does not replace, routine stylet use for intubation in morbidly obese patients, Anesth. anaLG., 109, 1560-5, 2009.

13. Globel F.L., Nordstrom L.A., Nelson R.R., Jorgensen C.R., Wang Y., The rate-pressure product as an index of myocardial oxygen consumption during excercise in patients with angina pectoris, circuLation, 57, 549-56, 1978.

14. Robinson B.F., Relation of heart rate and systolic blood pressure to the onset of pain in angina pectoris, circulation, 35, 1073-83, 1967.

15. Takahashi S., Mizutani T., Miyabe M., Toyooka H., Hemodynamic responses to tracheal intubation with laryngoscope versus lightwand intubating device (Trachlight) in adults with normal airway, anesth. anaLG., 95, 480-4, 2002. 
16. Kassiani T., Argyro F., Cardiovascular responses to laryngoscopy and tracheal intubation are not accompanied by ST-segment changes, eur. J. anaesth., 26, 520-35, 2009.

17. Thomson I. R., The haemodynamic response to intubation: a perspective, can. J. anesth., 36, 367-69, 1989. 


\section{The effect of cricoid pressure and backward upward rightward pressure on airway dimensions - implications for airway management?}

1. Author: Ralph L.J.G. Maassen. Title: Anaesthesiologist, MD. Affiliation: Departments of Anaesthesiology Catharina Hospital, Eindhoven, the Netherlands \& University Hospital Maastricht, the Netherlands. Email: Ralph.maassen@planet.nl

2. Author: Barbe M.A. Pieters. Title: Resident in Anaesthesiology, MD. Affiliation: Department of Anaesthesiology University Hospital Maastricht, the Netherlands. Email: bmapieters@ gmail.com

3. Author: Brando Maathuis. Title: bachelor of science. Affiliation: Department of Biomechanical Engineering, Mechanical, Materials and Maritime. Engineering, Delft University of Technology, Delft, the Netherlands Email: brandomaathuis@gmail.com

4. Author: Charl Botha. Title: assistant professor of medical visualization. Affiliation: Medical Visualization, Department of Mediamatics, TU Delft and Division of Image. Processing, Department of Radiology, University Hospital Leiden, the Netherlands. Email: c.p.botha@tudelft.nl

5. Author: Marco A.E. Marcus. Title: Professor of Anaesthesiology, MD, PhD. Affiliation: Department of Anaesthesiology, University Hospital Maastricht, the Netherlands. Email: m.marcus@mumc.nl

6. Author: André A.J. van Zundert. Title: professor of Anaesthesiology, MD, PhD, FRCA, EDRA, FANZCA Affiliation: Department of Anaesthesiology, Intensive Care and Pain Therapy, Catharina Hospital - Brabant Medical School, Eindhoven and Maastricht University, the Netherlands \& Ghent University Hospital, Ghent, Belgium. Email: Zundert@iae.nl

Study conducted at Catharina Hospital Eindhoven, the Netherlands

Registered at ClinicalTrials.gov (registration nr: NCT01679626) Conflict of interest: None

Address Correspondence: R.L.J.G. Maassen, Anaesthesiologist, MD; Department of Anesthesiology, Intensive Care and Pain Therapy, Catharina Hospital - Brabant Medical School, Michelangelolaan 2, NL-5623 EJ Eindhoven, The Netherlands. Address e-mail to ralph.maassen@planet.nl. Phone: +31 402399111 - Fax: + 31402463978

Submitted to the Journal of Clinical Anesthesia 


\section{Abstract}

Study Objective. The impact of extralaryngeal manoeuvers, on the effective glottic area for passage of the endotracheal tube is unknown. The objective of this study was to measure the change in mean anterior-posterior rima glottidis $\left(\mathrm{AP}_{\mathrm{RIMA}}\right)$ distance and mean area between the vocal cords after backward upward rightward pressure (BURP) and cricoid pressure (CP). Design. Prospective Study

\section{Setting. Operatingroom}

Patients. 200 adult patients (ASA PS I-III) scheduled for elective surgery requiring endotracheal intubation, were included in this study.

Measurements. The measurements assessed during BURP and CP, using a specially created module in the program DeVIDE, were expressed relative to the measurements when no external pressure was applied.

Main Results. The APRIMA distance decreased significantly $(\mathrm{P}<0.01)$ from $100 \%$ (no external pressure) to $51.9 \pm 27.2 \%$ (BURP) and $81.1 \pm 36 \%(\mathrm{CP})$. The mean glottic area (surface between the vocal cords), also decreased substantially $(\mathrm{P}<0.01)$ from $100 \%$ (no external pressure) to $29.7 \pm 22.6 \%$ (BURP) and $53.2 \pm 38.3 \%$ (CP).

Conclusion. This study shows a significant distortion of the upper airway anatomy after both BURP and CP manoeuvers. Further study regarding these manoeuvers in patients with a difficult airway is warranted.

Keywords: cricoid pressure, backward upward rightward pressure, airway dimensions

\section{Introduction}

Cricoid pressure described by Sellick in 1961 [1], and the backward-upwardrightward pressure (BURP) manoeuver described by Knill in 1993 [2], are extralaryngeal manoeuvers which are widely applied during endotracheal intubation, respectively offering potential protection against passive gastric regurgitation and improved laryngeal view in emergency airway management. Their validity in achieving an improvement of the laryngeal view has been questioned [3-5]. The impact of these manoeuvers on the effective glottic area for passage of the endotracheal tube is unknown, yet clinically relevant as effective airway management involves both achieving optimal laryngeal exposure and successfully securing the airway.

We hypothesized that both CP and the BURP manoeuvers both result in a decrease in the anterior-posterior rima glottidis $\left(\mathrm{AP}_{\mathrm{RIMA}}\right)$ distance and the area under the vocal cords, resulting in a reduced effective area for passage of the endotracheal tube. The objective of this study was to measure the change in visible mean $\mathrm{AP}_{\mathrm{RIMA}}$ distances and mean areas between the vocal cords following the application of BURP and CP, respectively. 


\section{Materials and Methods}

Study design

A prospective study to assess the influence of extralaryngeal manoeuvers (BURP manoeuver and cricoid pressure) on the effective area for passage of the endotracheal tube (ETT).

To quantify this effective space for the ETT, we measured anterior-posterior rima glottidis (APRIMA) distances and areas between the vocal cords (Fig. 1). The measurements assessed during BURP manoeuver and $\mathrm{CP}$ were expressed relative to the measurements without external pressure.

\section{Selection criteria}

After obtaining approval from the hospital medical ethics committee (Catharina hospital Eindhoven, the Netherlands) and obtaining written informed consent, 200 consecutive adult patients (ASA physical status I-III) scheduled for elective surgery requiring endotracheal intubation, were included in this study. The study was registered at ClinicalTrials.gov (registration nr: NCT01679626). The preanesthetic visit (performed by an anesthesiologist not involved in thisstudy) ascertained a history of difficult intubation, measurements of common predictive indices for difficult intubation (BMI, thyromental distance, Mallampati grade, interincisor or intergingival distances), and evaluation of dentition status. Patients who were obese $\left(\mathrm{BMI}>35 \mathrm{~kg} \cdot \mathrm{m}^{-2}\right)$; who had a history of chronic obstructive pulmonary disease or difficult intubation; a mouth opening $<3 \mathrm{~cm}$, inadequate neck mobility or any oropharyngeal pathology, were excluded.

On arrival at the operating room, patients were connected to standard monitoring devices and administered oxygen for at least $3 \mathrm{~min}$. A standardized sniffing position was applied to all patients. Anesthesia induction consisted of propofol $2.5 \mathrm{mg} \cdot \mathrm{kg}^{-1}$ and fentanyl $2.0 \mu \mathrm{g} . \mathrm{kg}^{-1}$ based on estimated lean body weight. Manual mask ventilation and inflation of the lungs were attempted via a face mask using sevoflurane in oxygen. Rocuronium 0.6 mg. $\mathrm{kg}^{-1}$ was administered once the ability to mask ventilate the patient was verified. Three minutes following the administration of rocuronium, adequate neuromuscular relaxation was tested using train of four (TOF)-monitoring. When adequate relaxation was not achieved, an additional dose of rocuronium was administered. Videolaryngoscopy was performed using the C-MAC ${ }^{\circledR}$ videolaryngoscope, with recording options for still images (Karl Storz, Tuttlingen, Germany). The Cormack Lehane grade was determined and recorded during direct laryngoscopy. 


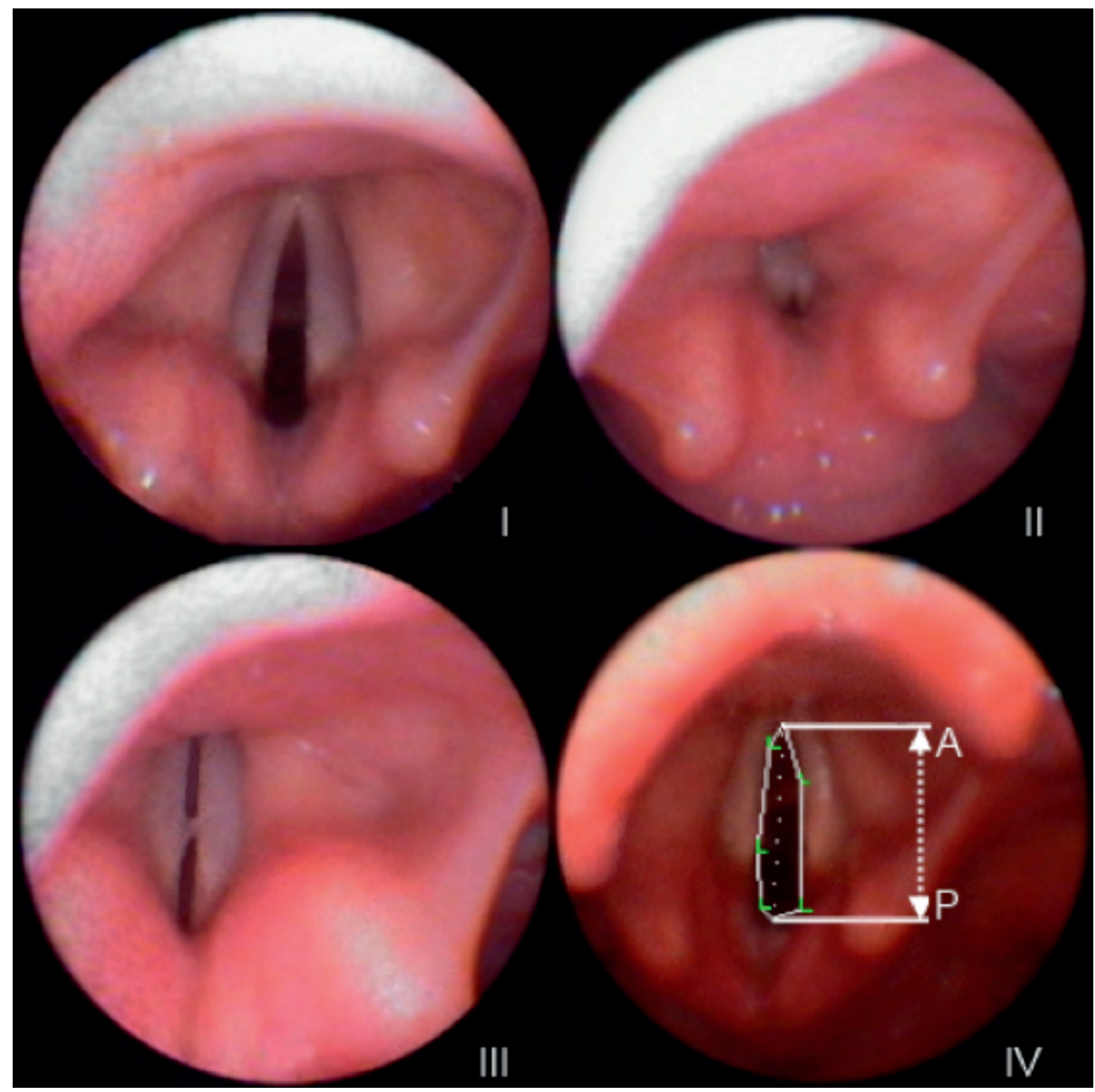

Figure 1. Photographs taken during laryngoscopy: I) before applying any external pressure on the trachea; II) during BURP manoeuver; III) during cricoid pressure; and IV) provide a screenshot of measurement in DeVIDE. 
An optimal view of the glottis was obtained on the monitor of the videolaryngoscope (VLS) by manipulating the VLS and three images were taken: 1) without any external pressure on the trachea, 2) during BURP maneuver, and 3) while applying CP (Fig. 1). The view of the glottis was blinded to the individual who performed any of these external manoeuvers. The operator paid attention not to alter the position of the videolaryngoscope while taking the pictures. Once the three images were obtained, direct laryngoscopy was performed with a Macintosh size 3 blade, Cormack and Lehane grading was assigned, the ETT was placed and normal anesthesia care was provided.

All images were stored on a laptop computer for analysis by an independent engineer not involved in the clinical part of the study, once the data of all patients was collected. The visible APRIMA distances and glottic areas were measured (Fig. 1-IV) by the engineer on the photographs using a specially created module (larynx measurement) in the program DeVIDE* (SimVis ${ }^{\circledR}$, Magdeburg, Germany). Each patient served as his or her own control. In this study, when no pressure was applied, the APRIMA distance was considered to be $100 \%$. The extra-laryngeal pressures were always applied by the same anesthesiologist and the measurements were all performed by the same engineer. The measurements assessed during the BURP manoeuver and CP were expressed relative to the measurements when no external pressure was applied.

Statistical Analysis

Statistical analysis was performed using SPSS for Windows version 16.0 (SPSS Inc. ${ }^{\circledR}$, Chicago, USA). Four t-tests were used for comparison of the relative changes in baseline mean glottic area and mean APRIMA distance before and after applying BURP and CP, respectively. Applying a Bonferroni correction for the 4 hypotheses yields a significant difference if $\mathrm{P}<0.0125$.

\section{Results}

Two hundred patients were recruited and included in this study. Patient characteristics and pre-procedural intubation conditions are listed in Table 1 . The pre- and intra-operative airway evaluation was normal in all patients: Mallampati grades 1 and 2 in $95 \%$ of patients, mean thyromental distance $(78 \pm 12 \mathrm{~mm})$, a normal distribution of the Cormack and Lehane grades (grade I 54.5\%; grade II 40.5\%; grade III 5\%; and grade IV 0\%). Peripheral oxygen saturation was maintained above $95 \%$ in all patients throughout videolaryngoscopy and extralaryngeal manoeuvers. Endotracheal intubation and surgical procedures proceeded uneventfully.

\footnotetext{
* Botha CP, Post FH (2008) Hybrid scheduling in the DeVIDE dataflow visualisation environment. Presented at simulation and visualization 2008 (SimVis 2008), Magdeburg, Germany).
} 
Table 1. Patient characteristics and pre- and intra-procedural intubation conditions.

\begin{tabular}{|l|c|}
\hline & Incidence $n=200$ \\
\hline Male: female, $n(\%)$ & $82: 118(41 / 59)$ \\
\hline Age, yrs & $53.9 \pm 18$ \\
\hline Weight, $\mathrm{kg}$ & $79.9 \pm 21$ \\
\hline Height, cm & $170 \pm 8$ \\
\hline ASA physical status; I:II:III:IV, $n(\%)$ & $57: 135: 8: 0(28.5: 67.5: 4: 0)$ \\
\hline Body mass index, kg.m-2 & $27.6 \pm 7.7$ \\
\hline Thyromental distance, mm & $78 \pm 12$ \\
\hline Mallampati grade; I:II:III:IV, $n(\%)$ & $109: 81: 10: 0(54.5: 40.5: 5: 0)$ \\
\hline Cormack and Lehane; grade I:II:III:IV, $n(\%)$ & $111: 58: 31: 0(55.5: 29: 15.5: 0)$ \\
\hline Dentition; full dentures:single:none, $n(\%)$ & $115: 30: 55(57.5: 15: 27.5)$ \\
\hline
\end{tabular}

Data are reported as $n(\%)$, or mean $\pm \mathrm{SD}$

This study demonstrated a significant decrease in both the mean APRIMA distance and mean glottic area. The mean $\mathrm{AP}_{\mathrm{RIMA}}$ distance decreased significantly $(\mathrm{P}<0.01)$ from $100 \%$ (no external pressure) to $51.9 \pm 27.2 \%$ during the BURP manoeuver and $81.1 \pm 36 \%$ during cricoid pressure (Fig. 2). The mean glottic area (surface between the vocal cords), also decreased substantially $(\mathrm{P}<0.01$ ) from $100 \%$ (no external pressure) to $29.7 \pm 22.6 \%$ during the BURP manoeuver and $53.2 \pm 38.3 \%$ during CP (Fig. 3).

\section{Discussion}

This study provides further evidence to the possible detrimental effects of extralaryngeal pressure (i.e. BURP and $\mathrm{CP}$ ) during endotracheal intubation, as both manoeuvers may result in a significant decrease in glottic dimensions. The BURP manoeuver and CP in this study resulted in significant reductions of the APRIMA (48\% and 19\%, respectively) and the area between the vocal cords ( $70 \%$ and $47 \%$, respectively). Keeping in mind that these manoeuvers have two different purposes (CP to protect the lungs from aspiration, BURP to improve visualization), this study was intended to determine the effect of each on airway dimensions regarding overall effectiveness at securing the airway.

To secure an airway requires both optimal visualization, as well as ability to place the ETT; however, these manoeuvers may seriously reduce the effective area for passage of the ETT and possibly traumatize the vocal cords in an already challenging airway, as the diameter of the ETT may be larger than the available glottic area. Although the latter 


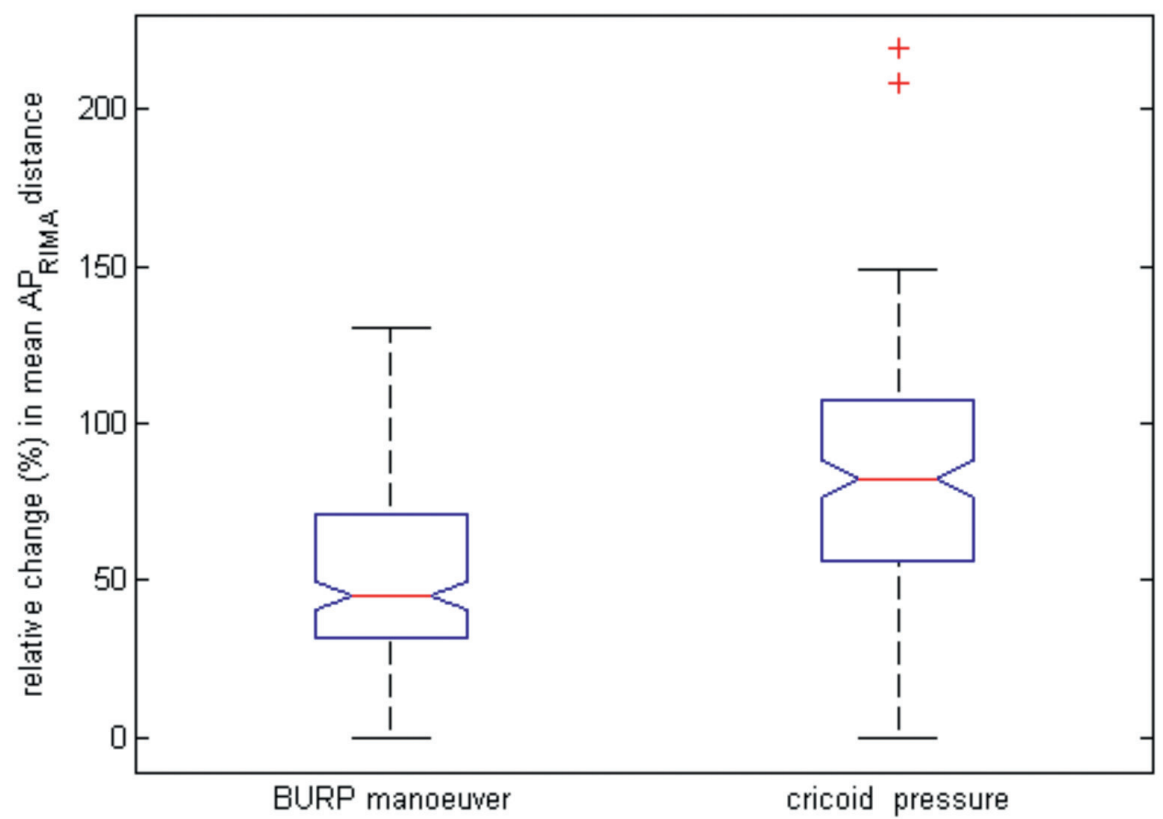

Figure 2. Box and whisker plots (median, upper and lower quartiles, range and outliers indicated) of the mean APRIMA distance for BURP and cricoid pressure. Both manoeuvers result in decreased AP $\mathbf{R I M A}_{\text {distances }}$ $(\mathrm{P}<\mathbf{0 . 0 1})$.

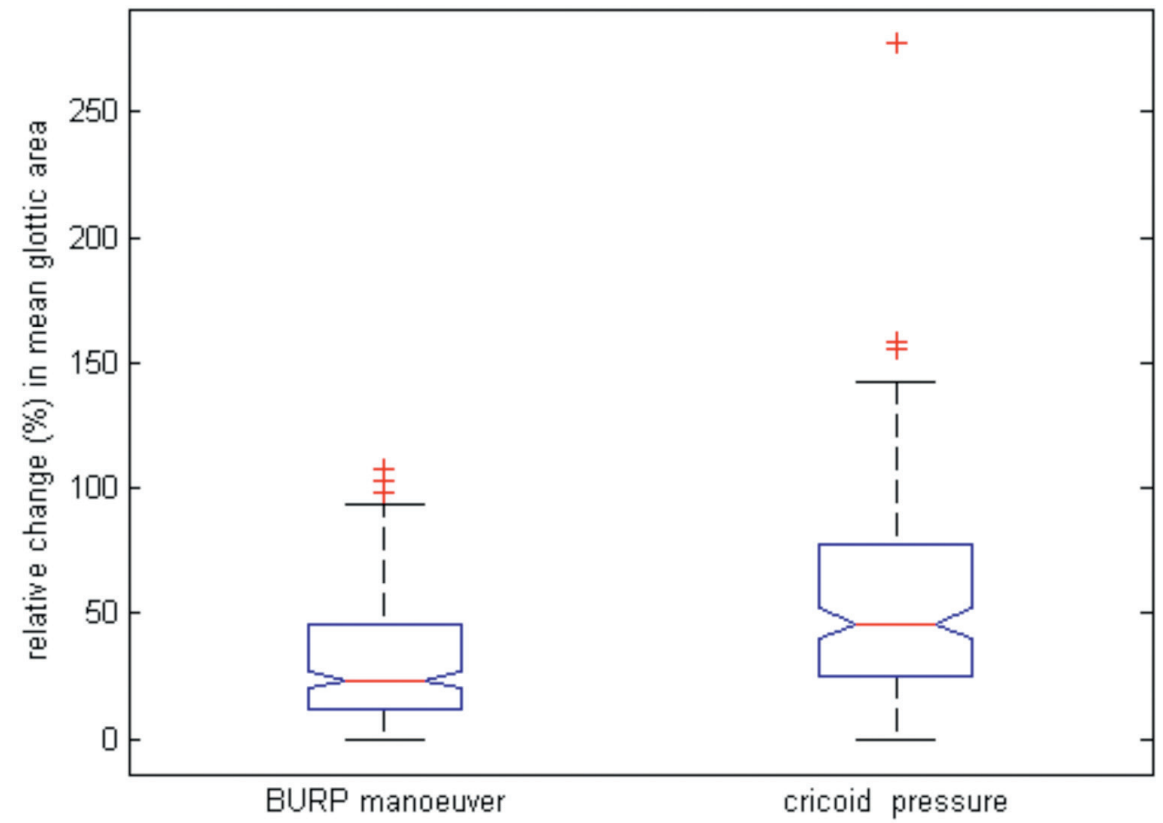

Figure 3. Box and whisker plots (median, upper and lower quartiles, range and outliers indicated) of the mean glottic area for BURP and cricoid pressure. Both manoeuvers result in smaller glottic areas $(\mathbf{P}<0.01)$. 
was not specifically tested, this study measured the relative changes in $\mathrm{AP}_{\mathrm{RIMA}}$ distance and mean glottic areas without measuring absolute distances and areas. Based on the significant reductions in mean $\mathrm{AP}_{\mathrm{RIMA}}$ distance and mean area between the vocal cords even in normal airways, it is likely that these airway manoeuvres could seriously interfere with optimal airway management in a difficult airway. However, if a small tube is used, a greater decrease in the measured values might be without any untoward effect on the ease of intubation.

Disadvantages of cricoid pressure have been extensively described in the literature, such as: partial or complete airway obstruction, difficult ventilation, deterioration of laryngeal view during direct laryngoscopy, difficult endotracheal intubation, decreased tidal volumes and increased inspiratory pressures [6-11].

The effect of CP on laryngeal view during direct laryngoscopy has recently been demonstrated in a prehospital setting by Harris and colleagues. They found that $\mathrm{CP}$ often causes blurring of the laryngeal view and makes the removal of $\mathrm{CP}$ necessary, thereby improving the laryngeal view in 50\% of cases, confirming the results obtained in this study. Even authors who have reported $\mathrm{CP}$ to have beneficial or neutral effects on laryngoscopy have emphasized that it has the potential to hinder laryngoscopy when performed with excessive force [5].

Although the BURP manoeuver may be helpful in cases of difficult direct laryngoscopy in order to visualize at least some parts of the vocal cords or arytenoids 12, a straightforward endotracheal intubation is not guaranteed. Snider and colleagues demonstrated that when the modified BURP manoeuver (a combination of BURP and CP) was applied to the cricoid cartilage, an additional worsening of the laryngoscopic view was observed in $30 \%$ of cases [13]. In our study, we determined that the BURP manoeuver compromises the effective area for passage of the ETT, more so than CP.

This study has several limitations: 1) the pressure applied to the larynx was not standardized using force measurement, however the force used was always applied by the same anaesthesiologist each time. Furthermore, extralaryngeal manoeuvers without a force measurement, resemble normal clinical practice; 2) Although the operator paid attention not to alter the position of the videolaryngoscope while taking pictures, small movements of the position of the videolaryngoscope could have occurred resulting in small errors on the pictures. Since this is an ad random deviation, positive and negative errors should cancel each other out and affect the results only marginally; 3) We did not test effective airway times (i.e. total time spent in the airway) while applying extralaryngeal pressure versus effective airway times without applying pressure; 4) This study was limited to patients whose preoperative examination suggested a normal airway anatomy with favorable intubation conditions. In other patients, the impediments of BURP and CP may be easily outweighed by their role in improving the glottic view during direct laryngoscopy. 


\section{Conclusion}

This study demonstrates a significant distortion of the upper airway anatomy following application of the BURP manoeuver and CP in patients with perimetrics of a normal airway. Further study regarding these manoeuvers in patients with a difficult airway is warranted.

\section{References}

1. Sellick BA. Cricoid pressure to control regurgitation of stomach contents during induction of anesthesia. Lancet. 1961; 2: 404-406.

2. Knill RL. Difficult laryngoscopy made easy with a "BURP." Can J Anaesth. 1993; 40: 798-9.

3. Harris T, Ellis DY, Foster L, Lockey D. Cricoid pressure and laryngeal manipulation in 402 pre-hospital emergency anaesthetics: Essential safety measure or hindrance to rapid safe intubation? Resuscitation 2010; 81: $810-6$.

4. Levitan RM, Kinkle WC, Levin WC, Everett WW. Laryngeal view during laryngoscopy: a randomized trial comparing cricoid pressure, backward-upward-rightward pressure and bimanual laryngoscopy. Ann Emerg Med 2006; 47: 548-55.

5. Haslam N, Parker L, Duggan JE. Effect of cricoid pressure on the view at laryngoscopy. Anaesthesia 2005; 60: $41-7$.

6. Allman KG. The effect of cricoid pressure application on airway patency. J Clin Anesth 1995; 7: 197-9.

7. Smith KJ, Dobranowski J, Yip G, Dauphin A, Choi PTL. Cricoid pressure displaces the esophagus: an observational study using magnetic resonance imaging. Anesthesiology 2003; 99: 60-4.

8. Palmer JH, MacG, Ball DR. The effect of cricoid pressure on the cricoid cartilage and vocal cords: an endoscopic study in anaesthetised patients. Anaesthesia 2000; 55: 263-8.

9. Hartsilver EL, Vanner RG. Airway obstruction with cricoid pressure. Anaesthesia 2000; 55: 208-11.

10. Hocking G, Roberts FL, Thew ME. Airway obstruction with cricoid pressure and lateral tilt. Anaesthesia 2001; 56: $825-8$.

11. Georgescu A, Miller JN, Lecklitner ML. The Sellick maneuver causing complete airway obstruction. Anesth Analg 1992; 74: 457-9.

12. Takahata O, Kuota M, Mamiya K, Akama Y, Nozaka T, Matsumoto H, Ogawa H. The efficacy of the "BURP" manoeuvre during a difficult laryngoscopy. Anesth Analg 1997 84: 419-21.

13. Snider DD, Clarke D, Finucane BT. The "BURP"maneuver worsens the glottic view when applied in combination with cricoid pressure. Can J Anaesth 2005; 52: 100-4. 
Chapter 9

General Discussion And Practical Implications 


\section{Introduction}

The difficult airway (DA) refers to different aspects, such as: difficult mask ventilation, difficult direct laryngoscopy (DL), difficult flexible bronchoscopic visualisation and difficult endotracheal intubation. Poor glottic visualisation is more likely to require prolonged or multiple laryngoscopies and intubation attempts and may subsequently be associated with complications, such as oxygen desaturation or airway and dental injuries. To minimize the risk due to difficult laryngoscopies and intubations, most of the national anaesthesia societies have developed guidelines for the management of the (un)expected difficult airway.

In the majority of patients, indirect videolaryngoscopy solves the problem of difficult or failed direct laryngoscopy and may play an important role in the unanticipated difficult airway and failed direct laryngoscopy.

This thesis focuses on the merits of videolaryngoscopy during glottic visualisation for endotracheal intubation and provides evidence that videolaryngoscopy is less traumatic than DL (i.e. less pressure on the upper incisors and less cardiovascular responses). Furthermore, we carried out performance studies using various videolaryngoscopes (VLSs) in normal and difficult airways.

Finally, we describe the effects of extralaryngeal manoeuvres on the glottic entrance, using the VLS as a research tool.

In this chapter, the outcome of our work on the merits of videolaryngoscopy is guardedly reviewed in order to assess the present position of videolaryngoscopy in airway management. The reassessment is performed by means of a SWOT analysis. The SWOT analysis is an excellent tool for understanding and decision-making for all sorts of situations in new technologies, business and health care organizations. SWOT analysis is an effective way to determine the Strengths, Weaknesses, Opportunities and Threats of our results as described in this thesis and might contribute to the final destination of videolaryngoscopy in airway management. 


\section{Strengths}

\section{Indirect Videolaryngoscopy versus Direct classic Laryngoscopy and Practical I mplications}

\section{Technical aspects of (video)laryngoscopy - Improved glottic visualisation}

During direct laryngoscopy, the larynx is viewed from outside the oral cavity. The distance between the vocal cords and the laryngoscopist's eye is substantial $(30-40 \mathrm{~cm})$, which reduces the anterior angle of view to $15^{\circ}$ with a classic laryngoscope. Indirect videolaryngoscopy solves the problem of difficult or failed direct laryngoscopy by obtaining a much wider angle of view as captured on the camera monitor. The total (anterior and posterior) angle of view is in theory $80^{\circ}$. This is provided by a digital camera and light source which are mounted very close $(2-3 \mathrm{~cm})$ to the tip of the videolaryngoscope and substantially closer to the vocal cords. However, the $80^{\circ}$ view angle provided by the lens is not visible in total because the anterior view is restricted by the tip of the blade itself, resulting in a visual angle of view of $60^{\circ}$. The alignment of the visual axis (necessary for adequate direct laryngoscopy), is not necessary during videolaryngoscopy and the need for optimizing manoeuvres is less during videolaryngoscopy [1].

\section{VLS \& Clinical performance - A less traumatic way of securing the airway}

The benefits of videolaryngoscopy are undoubtedly more distinct in difficult airways (C\&L grades III or IV) compared to the more easy ones (C\&L grades I and II), as videolaryngoscopy converts "blind" intubations into endotracheal intubations under visual control. In easy airways the intubation time was prolonged in videolaryngoscopy or was not significantly different compared to direct laryngoscopy [1-5].

In difficult airways, videolaryngoscopy offers not only upgrading of the C\&L grades but also results in higher intubation success rates, faster intubations and less need for optimizing manoeuvres. 1 The Macintosh blade mounted on a VLS seems to reduce, but not replace stylet use in easy and difficult to intubate patients [6,7]. As no stylet and pre-shaping of the ETT is required in most of the cases, the endotracheal intubation is usually performed much faster when a Macintosh blade is used for videolaryngoscopy, preventing potential complications from the stylet use.

When three VLSs were tested in morbidly obese patients, the Storz V-Mac had a better overall satisfaction score, faster intubation, less intubation attempts and less necessity for extra adjuncts compared with the GlideScope and the McGrath 5- series VLSs. The McGrath 5-series showed the worst performance among the three [7]. 
In addition, VLS seems to be less traumatic compared to direct classic laryngoscopy. Extreme forces on the upper incisors have been described during classic direct laryngoscopy in a difficult airway [8]. It seems needless to say that less oropharyngeal injuries and possible less dental injuries are caused if less force is applied to the soft tissues and upper incisors. Recent studies show that the force produced during videolaryngoscopy on the upper incisors is less if a Macintosh blade is used for videolaryngoscopy [9]. Furthermore, Macintosh-form blades create the widest palatopharyngeal arch, reducing the risk of palatopharyngeal injury during endotracheal intubation [10]. Cardiovascular responses during endotracheal intubation are less when VLS is used compared to DL, even when the patient is on beta blockade [11].

With adequate training and a short learning curve in the use of VLS, it has proven to be a fast, atraumatic technique. It is generally accepted that multiple attempts at classic direct laryngoscopy can convert a "cannot intubate but able to ventilate" situation to an "unable to intubate and ventilate" situation due to airway trauma and subsequent airway swelling [12-15]. Multiple attempts can cause airway bleeding which may make even VLS-guided endotracheal intubation difficult to perform. In February 2013 the VLS was finally adopted in the updated ASA "Difficult Airway Algorithm" [16]. A new step forward in patient safety.

\section{Weaknesses}

The clinical performance studies of various VLSs in normal and morbidly obese patients were restricted to the non-channelled type VLSs. The channeled VLS types were not studied in this thesis.

Our study comparing cardiovascular responses between VLS and classic DL, was also restricted to the use of a non-channelled type VLS. As our studies were restricted to non-channelled VLSs, we therefore cannot make any conclusion regarding the performance of channelled VLSs. Although we focused our attention on the extra space a Macintosh blade can achieve, we did not study further improvements in blade design.

It remains to be shown which geometry is optimal for various patient populations, and this should be a spin off for future research. Since line-of-sight in videolaryngoscopy is not required, the concept of axial alignment is redundant and it is perhaps more relevant to consider the curvature of the oral-pharyngeal-tracheal tract in the development of better optimized laryngoscopes. Considering the development of a new metric for identification of difficult patients for endotracheal intubation, the evidence that geometry plays such an important role should mean that patient mouth and throat anatomy is a key factor. 


\section{Opportunities}

A balance between the existence of two skills

In our opinion VLS will become the "golden" standard for all intubations, not only those predicted to be "difficult". However, we share the statement of El-Orbany [17] that the retention and development of DL skills are a necessity for all anaesthesiologists. There is however an alternative that preserves skill in DL whilst offering the advantages of VLS. Videolaryngoscopes with a Macintosh-form blade mounted, have the full functionality of either DL or VLS, providing two options for the attending anesthesiologist. It is an ideal tool for teaching and learning endotracheal intubation. VLS is far superior to the exclusive 'look over my shoulder' training available with DL alone. Additionally, VLS can be used as a research tool in airwaymanagement.

We published a performance study of different VLS in obese patients comparing the use of adjuncts with a variety of VLSs and DL in a population of morbidly obese patients [7]. The results of this study are quite consistent with the results of Andersen et al. [18] where the laryngeal view was superior with a videolaryngoscope (VLS) [GlideScope ${ }^{\circledR}$ (GS), Verathon Inc., Bothell, WA, USA], as was ease of intubation scored by the Intubation Difficulty Scale (IDS) as developed by Adnet et al. [19]. Although the latter demonstrated that the difference in intubation time between the GS and DL is not of clinical consequence, he showed that the intubation ease as assessed by the IDS was superior with the GS. If the ease of the intubation is greater, then there is a likely improvement of patient safety, not only to be measured in intubation time [20].

A failed laryngoscopy (i.e. Cormack and Lehane grades III and IV) seems to belong to the past in the overall majority of the patients undergoing endotracheal intubation using videolaryngoscopy. Even in rare cases when a C\&L grade III or IV is encountered with videolaryngoscopy, the VLS can prove helpful to achieve the best possible view and space of the laryngeal inlet for the insertion and navigating of another adjunct (e.g. the Bonfils ${ }^{\circledR}$ (Karl Storz, Tuttlingen, Germany) to secure the airway [21].

In our opinion the preferential use of a DL with (obese) patients, is to be considered as a potential disservice to the patient when a VLS is readily available. The ongoing improvement of VLS-blade design with superior light sources for the more distal airway should be encouraged to optimize glottic visualisation, enhance safety and further reduce the risk for trauma to the patients airway. 


\section{Threats}

Be aware of the "blind spot"

Airway trauma is described for both the "non-channelled" and the "channelled" VLS. Recently, it has been shown, in manikins (Airway Trainer ${ }^{\circledR}$, Laerdal Medical AS, Stavanger, Norway), that the space between the right side of the flange of the laryngoscope blade and the palatopharyngeal arch differs substantially across the VLS brands, with the widest space becoming available when a Macintosh-form blade $(15 \mathrm{~mm})$ is used. With the GlideScope ${ }^{\circledR}$ (Verathon Medical, Bothell, WA, USA) and McGrath ${ }^{\circledast}$ (Aircraft Medical Ltd, Edinburgh, UK) videolaryngoscopes, the room available for insertion of the ETT is reduced substantially ( 7 and $8 \mathrm{~mm}$, respectively). Sometimes, this space is even less than the diameter of the ETT, making the insertion of the ETT even more prone to traumatize the soft palate [10].

However, no reports of traumata can be found when (video)laryngoscopy is performed using a Macintosh-form blade. Furthermore, our clinical performance studies showed that the need for stylet use in different "non-channelled" VLS types is substantially less when a Macintosh-form blade is used [6,7]. In the minority of patients, a stylet may be needed as the less curved Macintosh blade laryngoscopes allows better illumination of the oral cavity, preventing possible airway trauma during insertion of the ETT.

Manufacturers of VLSs should focus on both blade design (leaving enough space for ETT insertion and other adjunctive equipment) and illumination of the oral cavity. Be aware of the "blind spot" of the current available "channelled " and "non- channelled" VLSs.

\section{Loss of proper DL skills}

The chance of losing proper DL skills is true for all VLS types, not having a Macintoshform blade mounted [22]. Earlier In this SWOT-analysis we emphasized the need for retention and development of DL skills and focused on the balance between DL and VLS skills.

There is a general concern that new technologies might affect an already familiar skill. However, by means of multi-disciplinary awareness, investigations and understanding of the superiority of VLS, patient outcome and quality of airway management have been shown to increase and further enhance safety. 
In an over enthusiastic interest in bringing new VLS-types on the market, the possibility arises that the creation of new VLS-types might become a company driven activity, instead of a well-studied medical adjunct to airway management.

However, putting some newly introduced VLS-types on the market into perspective it is reassuring that manufacturers are convinced of the superiority of a Macintosh-form blade mounted on a VLS.

We have to ensure that the implementation of new VLS-types will be based on proper validation, using manikin and clinical performance studies.

\section{Summarized SWOT analysis results regarding videolaryngoscopy}

\section{Strengths}

- Increased angle of view

- Increased patient safety by improved glottic visualisation

- Upgrading Cormack and Lehane grades

- Potentially less traumatic to patients

- Less need for styletted ETT when a Macintosh-form blade is mounted

- Less force applied to soft tissue and upper teeth

- Less cardiovascular responses

- Palatopharyngeal arch becomes widest when a Macintosh-form blade is used, reducing the risk of palatopharyngeal injury during endotracheal intubation

- Reserve the acute angulated blades for the most difficult airways

- Short learning curve (not this thesis)

- Macintosh-form blades facilitate both DL and VLS

- Videolaryngoscopy is adopted in the new ASA Difficult Airway Algorithm 2013

\section{Weaknesses}

- Only three common (in our hospital) available "non-channeled" type VLSs tested

- "Channeled" type VLSs not studied

- Cardiovascular responses only studied for non-channeled type VLS

- Mounted blade type

- Ease of endotracheal intubation is not merely a function of visual quality.

- Intubation time could increase when using VLS compared to DL

- Note: patient safety in airway management should not only be measured in intubation time 


\section{Opportunities}

- VLS has the potential to become the new universal gold standard in anaesthetic practice for all endotracheal intubations, not only for anticipated but also in the non- anticipated difficult airways.

- Even when a C\&L grade IV may be encountered with VLS, the VLS can prove helpful

- Further improvement of VLS-blade design to optimize glottic visualisation and minimize the risk for trauma to the patients airway

- The use of VLS as a research tool for further research in airway management (this thesis) and as a diagnostic tool

\section{Threats}

- Palatopharyngeal trauma due to "blind spot" when using VLS (during passage of ETT from mouth to larynx)

- Loss of proper DL skills (true for most VLS without a Macintosh-form blade)

- Company driven activities

- Fast implementation of new VLS-types without proper validation, using manikin and clinical performance studies 


\section{References}

1. Jungbauer A, Schumann M, Brunkhorst A, Borgers A, Groeben H. Expected difficult tracheal intubation: a prospective comparison of direct laryngoscopy and videolaryngoscopy in 200 patients. Br J Anaesth 2009; 102: 546-50.

2. Lim TJ, Lim Y, Liu EHC. Evaluation of ease of intubation with the GlideScope or Macintosh laryngoscope by anaesthetists in simulated easy and difficult laryngoscopy. Anaesthesia 2005; 60: 180-3.

3. Malik MA, Maharaj CH, Harte BH, Laffey JG. Comparison of Macintosh, Truview EVO2, Glidescope, and Airwayscope laryngoscope use in patients with cervical spine immobilization. Br J Anaesth 2008; 101: 723-30.

4. Sun DA, Warriner CB, Parsons DG, Klein R, Umedaly HS, Moult M.The GlideScope Video Laryngoscope: randomized clinical trial in 200 patients. Br J Anaesth 2005; 94: 381-4.

5. Enomoto Y, Asai T, Arai T, Kamishima K, Okuda Y. Pentax-AWS, a new videolaryngoscope, is more effective than the Macintosh laryngoscope for tracheal intubation in patients with restricted neck movements: a randomized comparative study. Br J Anaesth 2008; 100: 544-8.

6. Van Zundert A, Maassen R, Lee R, Willems R, Timmerman M, Siemonsma M, Buise M, Wiepking M. A Macintosh laryngoscope blade for videolaryngoscopy reduces stylet use in patients with normal airways. Anesth Analg 2009; 109: 825-31.

7. Maassen R, Lee R, Hermans B, Marcus M, van Zundert A. A comparison of three videolaryngoscopes: the Macintosh blade reduces, but does not replace, routine stylet use for intubation in morbidly obese patients. Anesth Analg. 2009; 109: 1560-5.

8. Maassen R, Lee R, van Zundert A, Cooper R. The videolaryngoscope is less traumatic than the classic laryngoscope for a difficult airway in an obese patient. J Anesth. 2009; 23 (3): 445-8.

9. Lee RA, van Zundert AA, Maassen RL, Wieringa RL. Forces applied to the maxillary incisors by video laryngoscopes and the Macintosh laryngoscope. Acta Anaesthesiol Scand 2012 Feb; 52: 224-9.

10. A van Zundert, B Pieters, T van Zundert, S Gatt. Avoiding palatopharyngeal trauma during videolaryngoscopy: do not forget the 'blind spots'. Acta Anaesthesiol Scand 2012; 56: 532-534.

11. Maassen RL, Pieters BM, Maathuis B, Serroyen J, Marcus MA, Wouters P, van Zundert AA. Endotracheal intubation using videolaryngoscopy causes less cardiovascular response compared to classic direct laryngoscopy, in cardiac patients according a standard hospital protocol.Acta Anaesthesiol Belg. 2012; 63: 181-6.

12. Mort TC. Emergency tracheal intubation:complications associated with repeated laryngoscopic attempts. Anesth Analg 2004; 99: 607-13.

13. Domino KB, Posner KL, Caplan RA, Cheney FW. Airway injury during anesthesia: a closed claims analysis. Anesthesiology 1999; 91: 1703- 11.

14. Thierbach AR, Lipp M. Airway management in trauma patients. Anesthesiol Clin North America 1999; 71: 6381.

15. Peterson GN. Management of the difficult airway: a closed claims analysis. Anesthesiology 2005; 103: 33-9.

16. Apfelbaum JL, Hagberg CA, Caplan RA, Blitt CD, Connis RT, Nickinovich DG, Hagberg CA, Caplan RA, Benumof JL, Berry FA, Blitt CD, Bode RH, Cheney FW, Connis RT, Guidry OF, Nickinovich DG, Ovassapian A. Practice guidelines for management of the difficult airway: an updated report by the American Society of 
Anesthesiologists Task Force on Management of the Difficult Airway. Anesthesiology. 2013 Feb; 118: 251-70.

17. El-Orbany M. Will direct laryngoscopy become an extinct skill? Acta Anaesthesiol Scand 2012; 56: 260.

18. Andersen LH, Rovsing L, Olsen KS. GlideScope videolaryngoscope vs. Macintosh direct laryngoscope for intubation of morbidly obese patients: a randomized trial. Acta Anaesthesiol Scand 2011; 55: 1090-7.

19. Adnet F, Borron SW, Racine SX, Clemessy JL, Fournier JL, Plaisance P, Lapandry C. The intubation difficulty scale (IDS): proposal and evaluation of a new score characterizing the complexity of endotracheal intubation. Anesthesiology 1997; 87: 1290-7.

20. Lee RA, van Zundert AAJ, Maassen RLJG, Wieringa PA. Forces applied to the maxillary incisors by video laryngoscopes and the Macintosh laryngoscope. Acta Anaesthesiol Scand 2012; 56: 224-9.

21. Van Zundert AA, Pieters BM. Combined technique using videolaryngoscopy and Bonfils for a difficult airway intubation. Br J Anaesth 2012; 108: 327-8.

22. Lee RA, van Zundert AA. Ensuring direct laryngoscopy will not become an extinct skill. Acta Anaesthesiol Scand 2012; 56:803. 
Chapter 10

\section{English Summary}


This thesis deals with technological advancement around airway management, laryngoscopy, laryngoscope design and especially the merits of videolaryngoscopy during glottic visualisation for endotracheal intubation. Endotracheal intubation is a common technique applied with general anesthesia whereby a tube is inserted into the mouth and through the trachea of the patient for the purposes of respiration.

To perform a safe endotracheal intubation, atraumatic glottic visualisation is essential. Classically endotracheal intubation is performed using direct laryngoscopy. However poor glottic visualization (Cormack and Lehane (C\&L) grades 3 and 4) with classic direct laryngoscopy is encountered between $1 \%$ and $9 \%$ of attempts, requiring prolonged or multiple intubation attempts. This phenomenon goes hand-in- hand with complications that may have serious consequences. A failed laryngoscopy (i.e. C\&L grades III and IV) seems to belong to the past in the overall majority of the patients undergoing endotracheal intubation using videolaryngoscopy.

Previous studies from our research group on videolaryngoscopy gave the spin off for this thesis and an extra ordinary study case (Chapter 2) describes the anaesthetic management of an obese patient with a difficult airway and the merits of videolaryngoscopy, specifically in terms of the reduced risk of dental damage during intubation.

In Chapter 3, several advantages of videolaryngoscopy over direct classic laryngoscopy are suggested. Despite the clear advantages of videolaryngoscopy over classic direct laryngoscopy, there are differences in patient outcome between the commercially available VLSs. In this chapter the need for clinical performance studies is stressed by the authors. Furthermore, we pointed out that videolaryngoscopy is a promising improvement in airway management and we believe that videolaryngoscopy will become the "golden" standard for all intubations, not only those predicted to be "difficult". In 2008, we already suggested the need for adjusting the "Difficult Airway Algorithm" with the introduction of new tools in our practice, such as videolaryngoscopy.

To overcome certain deficits several manufacturers of videolaryngoscopes advocate the use of a styletted endotracheal tube, which may in itself be traumatic to the patient. Subsequently, we performed clinical performance studies with three common (in our hospital) available VLSs in normal and difficult airways to study the use of adjuncts (e.g. stylet, gum elastic bougie), time and subjective intubation ease when using modern VLSs compared to a classic Macintosh blade. 
In chapter 4, we investigated the ease of intubation using three VLSs in an elective surgery patient population. We considered the quality and ease of laryngoscopy with both classic Macintosh blade and one of the three videolaryngoscopes in a population of 450 elective surgery patients. The study illustrated that the use of an adjunct is significantly reduced by using a Macintosh blade form. Although all VLSs provided a unanimously excellent view of the glottic arch, the insertion of the endotracheal tube was not equally straightforward. This led to greater satisfaction in relation to the use of the Macintosh shaped blade.

Essentially the stylet seems to compensate for the geometrical mismatch between some laryngoscope blade forms and the patient anatomy. The use of adjuncts is undesirable as it requires additional dexterity and is associated with rare but sometimes serious complications.

In chapter 5, the same three VLSs were also examined in a more challenging patient population of morbidly obese patients (BMI exceeding $35 \mathrm{~kg} . \mathrm{m}-2$ ). As with the previous study, the VLSs provided an unequivocally superior view of the glottic arch compared to the classic Macintosh laryngoscope. As with the 'normal' patient population, the ease of intubation was not equal between the different videolaryngoscopes. The VLS with the Macintosh blade form required significantly less attempts to secure the airway and less need for stylet use. High quality visualization of the glottic arch is not sufficient to ensure an easy intubation. The geometrical form of the laryngoscope blade seems an important parameter in determining the ease of endotracheal intubation.

In a Letter-to-the-Editor (Chapter 6) we explained why we disagree with the statement that evaluation of videolaryngoscopes in the clinical setting receives little if any independent evaluation. McElwain et al. performed a manikin study where they compared the C-MAC ${ }^{\circledR}$ VLS, with the classic Macintosh laryngoscope, the GlideScope ${ }^{\circledR}$ and the Airtraq $^{\circledR}$. Their findings in this manikin study are congruent to the results we experienced in our clinical performance studies (Chapter 4 and 5).

In Chapter 7, we examined the cardiovascular responses during videolaryngoscopy and classic direct laryngoscopy. The cardiovascular response curves were both tested for patients with and without beta blocker therapy. The cardiovascular responses during endotracheal intubation using videolaryngoscopy were less compared to direct classic laryngsocopy for all patients. 
In Chapter 8, we used the VLS as a research tool and examined the effect of cricoid pressure (CP) and backward upward rightward pressure (BURP) on airway dimensions. This study shows a significant distortion of the upper airway anatomy after both CP and BURP manoeuvers in patients with perimetrics of a normal airway.

Chapter 9 is entitled: General Discussion and Practical Implications.

In this chapter our work on the merits of videolaryngoscopy is guardedly reviewed in order to assess the present position of videolaryngoscopy in airway management, using a SWOT analysis.

Chapter 10 includes an English and Dutch summary.

The addenda contain curriculum vitae, acknowledgment and list of publications. 
Chapter 10

\section{Dutch Summary}


Dit proefschrift gaat over de technologische ontwikkelingen ten aanzien van luchtweg management, laryngoscoop design en met name de verdiensten van videolaryngoscopie tijdens visualisatie van de glottis ten behoeve van endotracheale intubatie. De glottis is de combinatie van de stembanden en de ruimte daartussen (rima glottidis of stemspleet). Endotracheale intubatie is een veel toegepaste techniek tijdens algehele anesthesie, waarbij een buisje (tube) wordt ingebracht via de mond. De tube wordt tussen de stembanden door in de luchtpijp van de patiënt ingebracht om te kunnen beademen.

Om een veilige endotracheale intubatie te kunnen uitvoeren, is het atraumatisch in beeld brengen van de stemspleet van essentieel belang. Klassiek wordt de intubatie uitgevoerd met behulp van directe laryngscopie. Echter, een slechte visualisatie van de stemspleet (Cormack and Lehane (C\&L) graad 3 en 4) tijdens directe laryngoscopie komt voor tussen de $1 \%$ en $9 \%$ van de pogingen tot intubatie. Dit kan zorgen voor een vertraging met multipele pogingen om de intubatie tot stand te brengen. Dit fenomeen gaat gepaard met complicaties die serieuze gevolgen hebben voor de patiënt. Een mislukte laryngoscopie (C\&L graad 3 en 4)

lijkt in de meerderheid van de gevallen tot het verleden te behoren sinds de ontwikkeling van videolaryngoscopie.

Eerdere studies met betrekking tot videolaryngoscopie van onze onderzoeksgroep zorgden voor de start van dit proefschrift. Een uitzonderlijke studiecasus (Hoofdstuk 2) beschrijft het anesthesiologisch beleid van een obese patiënt met een moeilijke luchtweg en de verdiensten van videolaryngoscopie met betrekking tot het gereduceerde risico op tandschade tijdens intubatie.

In Hoofdstuk 3 worden verschillende voordelen van videolaryngoscopie boven directe laryngoscopie beschreven. Ondanks de duidelijke voordelen van videolaryngoscopie boven directe laryngoscopie, zijn er verschillen in gebruiksgemak en veiligheid voor de patiënt tussen verschillende gangbare videolaryngoscopen. In dit hoofdstuk wordt de noodzaak van klinische perfomance studies benadrukt. Wij zijn van mening dat de videolaryngoscoop een belangrijke technologische ontwikkeling is in het kader van veiliger luchtweg management. Videolaryngoscopie zal uiteindelijk de "gouden standaard" worden voor alle endotracheale intubaties. In 2008 suggereerden wij reeds dat technologische ontwikkelingen met een bewezen vooruitgang in de klinische praktijk, zoals de videolaryngoscoop, een plaats verdienen in het ASA "Difficult Airway Algorithm".

In Hoofdstuk 4 hebben we het intubatiegemak getest in een electieve chirurgische patiënten groep (450 patiënten), waarbij drie videolaryngoscopen met elkaar vergeleken werden. De kwaliteit en gemak van de laryngoscopie werden getest. Hierbij werd de directe klassieke laryngoscopie met een Macintoshblad vergeleken met een van de drie videolaryngoscopen. De studie toonde dat de noodzaak tot het gebruik van een hulpmiddel (bijv. stylet) significant 
gereduceerd was wanneer de videolaryngoscoop was uitgerust met een Macintosh blad.

Alle drie de videolaryngoscopen zorgden voor een betere weergave van de glottisapertuur in vergelijking met klassieke directe laryngoscopie. Echter, de daadwerkelijke endotracheale intubatie was niet altijd even gemakkelijk. Er was sprake van een grotere tevredenheid bij de videolaryngoscoop die was uitgerust met een Macintosh blad. In essentie lijkt de stylet te compenseren voor de geometrische wanverhouding tussen verscheidene laryngoscoopbladen en de anatomie van de patiënt. Het gebruik van dit soort hulpmiddelen is niet wenselijk aangezien het extra behendigheid vereist en geassocieerd is met zeldzame maar ernstige complicaties.

In Hoofdstuk 5 werden dezelfde drie videolaryngoscopen onderzocht in een meer uitdagende patiënten groep bestaande uit 150 patiënten met morbide obesitas (BMI > 35 kg.m2). In deze studie zorgden de videolaryngscopen eveneens voor een betere visualisatie van de glottisapertuur in vergelijking met klassieke directe laryngoscopie. Ook in deze complexere patiëntenpopulatie was het intubatiegemak niet hetzelfde voor de verschillende videolaryngoscopen. De videolaryngoscoop uitgerust met het Macintosh blad vereiste minder pogingen om de luchtweg te zekeren. De noodzaak tot het gebruik van een stylet was het minst noodzakelijk bij de videolaryngoscoop met een Macintosh blad. De geometrie van het laryngoscoop blad lijkt ook in deze populatie de sleutel tot succes.

In een Letter-to-the-Editor (Hoofdstuk 6) leggen we uit waarom we het niet eens zijn met de stelling dat de evaluatie van videolaryngoscopen in de klinische setting weinig tot geen aandacht krijgt. De onderzoeksgroep van McElwain voerde een mannequin studie uit waar zij de C-MAC ${ }^{\circledR}$ videolaryngoscoop vergeleken met de klassieke directe Macintosh laryngoscopie, de GlideScope ${ }^{\circledR}$ en de Airtraq ${ }^{\circledR}$. Hun bevindingen waren vergelijkbaar met de resultaten van onze klinische performance studies.

In Hoofdstuk 7 worden de cardiovasculaire responscurves tijdens videolaryngoscopie vergeleken met klassieke directe laryngoscopie. Deze responscurves werden zowel getest voor patiënten met als zonder bèta blokkade. De hemodynamische responsen tijdens endotracheale intubatie waren minder uitgesproken tijdens videolaryngoscopie dan tijdens directe klassieke laryngoscopie.

In Hoofdstuk 8 wordt de videolaryngoscoop gebruikt als een onderzoeksinstrument om het effect van cricoid druk en "backward upward rightward pressure" (BURP) te meten. De reductie van de glottisapertuur tijdens deze manoeuvres wordt in maat en getal uitgedrukt. Het blijkt dat deze extralaryngeale manoeuvres een significante verstoring geven van de bovenste luchtweg anatomie bij patiënten met een normale luchtweg. 
Hoofstuk 9 is de Discussie waarin dit proefschrift kritisch wordt geanalyseerd door middel van een SWOT analyse. Hierbij wordt de plaats van de videolaryngoscoop in de huidige anesthesiologische praktijk bepaald.

Hoofdstuk 10 bevat de Engelse en Nederlandse Samenvatting van dit proefschrift.

De addenda bevatten curriculum vitae, dankwoord en lijst van publicaties. 
Addenda

Acknowledgements - Dankwoord 
Prof. Dr. A.A.J. van Zundert, beste André,

Als mijn opleider in het tweede jaar van mijn opleiding tot anesthesioloog, gaf jij me de kans op dit promotietraject te starten. Hiervoor ben ik je ontzettend dankbaar. Voor mij ben je een echte "inspirator" en "multitasker pur sang"!

Ik heb veel bewondering voor de manier waarop je de klinische anesthesiologie combineert met het uitvoeren van wetenschappelijk onderzoek. Jouw aanmoedigingen en eindeloos enthousiasme hebben me vooral in de laatste fase van dit project erdoorheen gesleept. Chapeau et merci voor je ondersteuning, vertrouwen en vriendschap!

\section{Prof. Dr. M.A.E. Marcus, beste Marco,}

Als opleider gaf jij me de kans en het vertrouwen om tijdens mijn opleiding tot anesthesioloog dit project te starten. Je gaf me hiervoor "carte blanche". Jij hebt ervoor zorg gedragen, dat ik mijn volledige wetenschaps differentiatie kon voltooien in het Catharina ziekenhuis Eindhoven. Het is een hoop geregel, maar dan heb je ook wat. Bedankt!

\section{Ruben Lee, beste Ruben,}

Met name aan het begin van dit project hebben we vaak samengewerkt. De ene keer in het Catharina ziekenhuis de andere keer bij André thuis. Dank voor jouw bijdrage! Jij deed, net als ik, promotieonderzoek bij André en promoveert ook deze week. Van harte gefeliciteerd!

\section{Brando Maathuis, beste Brando,}

Dank voor je ondersteuning tijdens verschillende studies van dit project. We hebben heel wat afgebeld, gelachen en gemaild om een en ander op orde te krijgen (..."grafiekje hier, tabelletje daar”...).

Dankzij jou heb ik ook de waardevolle ondersteuning van jouw collega Carl Botha gehad ten behoeve van het schrijven van het programma Devide.

Bedankt! Nu is het klaar en kunnen we het projectje afvinken: "check”!

\section{Jan Serroyen, beste Jan,}

Bedankt voor de statistische ondersteuning bij de studie naar de cardiovasculaire responsen op directe laryngoscopie versus VLS. Dankzij jouw inzet is deze studie tot een succes geworden. Een dikke merci!

\section{Jan-Wouter Brunings, beste Jan-Wouter,}

Bedankt voor het maken van de prachtige coverfoto van dit proefschrift. Het spreekt tot de verbeelding, dit is "the finishing touch"! 


\section{Mark Spigt, beste Mark,}

Bedankt voor de waardevolle "klankbord sessies" onder het genot van een heerlijk glas wijn en lekker eten. Ik stel voor deze sessies ook na het afronden van dit project samen met Maud, Suzanne en de kinderen gewoon voort te zetten. Gezellig!

\section{OK personeel en maatschap anesthesiologie Catharina ziekenhuis Eindhoven.}

Dank voor jullie gastvrijheid en ondersteuning tijdens de klinische studies.

"Daar komt hij weer met de stopwatch".....Nu is het tijd om de werkelijke eindtijd op te nemen: 6 jaar en 3 maanden.

\section{Hermina Gielen, beste Hermina,}

Dank voor al het regelen, mailen en bellen in de afrondende fase van dit project. Mede door jou is de afronding supersnel tot stand gekomen. Fantastisch!

\section{Roland Beuk, beste Roland,}

Ik heb veel van je geleerd tijdens mijn student-assistentschap in het kader van jouw promotieonderzoek. We hebben in die tijd intensief samengewerkt om de dierexperimenten te voltooien. Het was een gezellige en leerzame periode, waarin ik vaardigheden heb opgedaan die ik goed heb kunnen gebruiken tijdens mijn eigen promotietraject. De prachtige stage in Nieuw Zeeland in 2000 heb ik eigenlijk aan jou te danken.

Maatschap anesthesiologie en pijnbestrijding van het Laurentius ziekenhuis, beste maatjes, Tijdens de laatste loodjes was jullie steun van grote waarde. Ik dank jullie allemaal voor het in mij gestelde vertrouwen om dit project tot een goed einde te brengen. Dank voor de extra vrije tijd die jullie mij gunden.

Yolande, Carla, Ingrid, Khaled, Raymond, Jon en Luuk, we proosten op nog vele mooie jaren in Remunj!

\section{Yvon Thiessen, beste Yvon,}

Bedankt voor je ad hoc SPSS-ondersteuning. Het heeft me een hoop frustratie bespaard!

\section{Barbe Pieters, beste Barbe,}

Ook jij werd, net als ik, door André geïntroduceerd in de wereld van de videolaryngoscopie. Dank voor de bijdrage die je hebt geleverd en heel veel succes met het afronden van jouw eigen promotietraject! 


\section{Remi Willems, beste Remi,}

Allereerst bedankt voor je vriendschap! Dat er nog maar vele congresreisjes, etentjes en borrelmomenten mogen volgen. Gezelligheid kent geen tijd, carpe diem!

Natuurlijk was (en is) jouw ICT ondersteuning altijd waardevol.

Fijn, dat je mijn paranimf wil zijn op deze onvergetelijke dag!

\section{Leon Maassen, mijn broertje, beste Leon,}

Ook jouw project is absoluut geslaagd: een eigen bedrijf. De "Verbé Installatiegroep" is onder jouw leiding een florerend bedrijf. Het is voor mij altijd interessant om met jou over niet-medische dingen te praten en samen met Sabrina, Suzanne en mam te genieten van de kinderen. We gaan gestaag op deze voet verder.

Ik ben vereerd dat jij mijn paranimf wil zijn op deze prachtige dag!

\section{Mam,}

Het is dan eindelijk zover. De promotie is klaar. Een moment waar jij naar uit gekeken hebt. Pap is helaas veel te vroeg overleden, maar jij hebt altijd gezorgd voor een stabiele thuishaven en hebt mij en Leon de mogelijkheid gegeven om ons maximaal te ontwikkelen. Zonder jou was dit zeker niet gelukt. Ik ben ervan overtuigd dat pap met voldoening en vreugde naar ons kijkt. We hebben het toch maar geflikt met z'n drieën. Ons leven werd verrijkt door Sabrina, Suzanne en jouw 6 kleinkinderen. We kunnen dankbaar zijn!

\section{Suzanne,}

2013 is ons jaar! 10 jaar getrouwd, de geboorte van Charlotte en de afronding van mijn promotie...een opeenstapeling van mooie "life-events". Zonder jouw onvoorwaardelijke steun was dit project onmogelijk geweest.

In één woord: geweldig!

\section{Jules, Yves en Charlotte,}

Nu heeft papa nog meer tijd om met “Johnny” (onze John Deere ${ }^{\circledR}$ zitmaaier) rondjes door de tuin te rijden, te maaien en samen met jullie te tuinieren! Heerlijk! 
Addenda

List of Publications 
(1) Maassen R, Lee R, van Zundert A, Cooper R. The videolaryngoscope is less traumatic than the classic laryngoscope for a difficult airway in an obese patient. J Anesth. 2009; 23: 445-8.

(2) Maassen R, Lee R, Hermans B, Marcus M, van Zundert A. A comparison of three videolaryngoscopes: the Macintosh blade reduces, but does not replace, routine stylet use for intubation in morbidly obese patients. Anesth Analg. 2009 Nov; 109: 1560-5.

(3) Van Zundert A, Maassen R, Lee R, Willems R, Timmerman M, Siemonsma M, Buise M, Wiepking M. A Macintosh laryngoscope blade for videolaryngoscopy reduces stylet use in patients with normal airways. Anesth Analg 2009; 109: 825-31.

(4) Van Zundert A, Maassen R, Hermans B, Lee R. Videolaryngoscopy - making intubation more successful. Acta Anaesthesiol Belg 2008; 59: 177-8.

(5) Lee RA, Zundert AA, Maassen RL et al. Forces applied to the maxillary incisors during video-assisted intubation. Anesth Analg 2009; 108: 187-91.

(6) Maassen R, van Zundert A. Comparison of the C-MAC videolaryngoscope with the Macintosh, Glidescope and Airtraq laryngoscopes in easy and difficult laryngoscopy scenarios in manikins. Letter-to-the Editor. Anaesthesia 2010; 65: 955.

(7) Lee RA, van Zundert AA, Maassen RL, Wieringa PA. Forces applied to the maxillary incisors by video laryngoscopes and the Macintosh laryngoscope. Acta Anaesthesiol Scand 2012; 56: 224-9.

(8) Maassen R, Pieters B, Maathuis B, van Zundert A. The effect of cricoid pressure and backward upward rightward pressure on airway dimensions - implications for airway management? Submitted Journal of Clinical Anesthesia 2013.

(9) Maassen R, Pieters B, Maathuis B, Serroyen J, Marcus M, van Zundert A. Endotracheal intubation using videolaryngoscopy causes less cardiovascula responses compared to classic direct laryngoscopy in cardiac patients according a standard hospital protocol. Acta Anaesthesiologica Belgica 2012 2012; 63: 181-6.

(10) Beuk RJ, Tangelder RL, Maassen RL, Quaedackers JS, Heineman E, Oude Egbrink MG. Leucocyte and platelet adhesion in different layers of the small bowel during experimental total warm ischaemia and reperfusion. Br J Surg 2008; 95: 1294-304. 


\section{(Inter)national Meetings:}

(1) ASA (Annual Meeting) 2009, New Orleans, Louisiana. October 17 - 22, 2009.

Poster Discussion: "Routine use of a styletted endotracheal tube is not required during intubation of morbidly obese patients during videolaryngoscopy if a Macintosh laryngoscope blade is used". Maassen R.

(2) NYSORA World Anesthesia Congress 2010, Dubai March 7-12, 2010

Maassen R. Faculty member - Airway Management.

(3) $7^{\mathrm{e}}$ Wetenschapsdag Anesthesiologie, De Reehorst, Ede. 24 September 2010.

Poster Walk Around: "Endotracheal intubation using videolaryngoscopy causes less cardiovascular responses compared to classic direct laryngoscopy". Maassen R.

(4) NYSORA World Anesthesia Congress 2011, Rome April 11-15, 2011-03-23

Maassen R. Faculty member-Airway Management.

(5) “Airway Dag Rotterdam”, Erasmus mc. 2010 \& 2011. Invited speaker. 
Addenda

Curriculum Vitae 
Ralph Maassen werd geboren op 4 juni 1977 te Sittard. Hij behaalde zijn gymnasiumdiploma aan het Bisschoppelijk College te Sittard in 1995. Aansluitend behaalde hij in 1996 zijn propedeuse Gezondheidswetenschappen. In dit jaar startte hij de studie geneeskunde. Tijdens zijn studie was hij van 1998 tot en met 2000 student-assistent bij de vakgroep Heelkunde (MUMC+) onder begeleiding van dr. R.J. Beuk en deed wetenschappelijk onderzoek naar de effecten van ischemie en reperfusie op de rattendarm. Van april tot en met september 2000 verrichtte hij zijn wetenschapsstage aan het Research Centre for Developmental Medicine and Biology (RCDMB) aan de universiteit van Auckland, Nieuw Zeeland onder begeleiding van Prof. dr. E. Heineman en dr. M.G.A. oude Egbrink.

In 2002 rondde hij zijn geneeskunde studie af en startte als arts-assistent op de afdeling intensive care te Heerlen (Juli 2002 - Mei 2003). Vervolgens werkte hij als arts-assistent op de afdeling heelkunde van het Orbis Medisch Centrum te Sittard (Juni 2003 - Februari 2005). In 2005 maakte hij een korte carrière switch van de tweede naar de eerste lijn (Maart 2005 December 2005).

In Januari 2006 startte hij zijn opleiding tot anesthesioloog aan het MUMC+ te Maastricht en het Catharina ziekenhuis te Eindhoven. Ten tijde van zijn opleiding tot anesthesioloog, startte hij in Juli 2007 zijn promotieonderzoek "The Merits of Videolaryngoscopy during Glottic Visualisation for Endotracheal Intubation". Van Januari 2011 tot en met November 2011 werkte hij als anesthesioloog, chef de clinique in het Atrium Medisch Centrum te Heerlen. Sinds December 2011 werkt hij als anesthesioloog in vrije vestiging in het Laurentius Ziekenhuis te Roermond. 